\title{
CARACTERIZAÇÃO FÍSICO-QUÍMICA DE MÉIS DE Apis mellifera L., 1758 (HYMENOPTERA: APIDAE) DE DIFERENTES MUNICÍPIOS DO ESTADO DE SÃO PAULO
}

\author{
SÔNIA SHIGUEYO KOMATSU \\ Engenheiro Agrônomo
}

Orientador: Prof. Dr. LUÍS CARLOS MARCHINI

Tese apresentada à Escola Superior de Agricultura "Luiz de Queiroz", da Universidade de São Paulo, para obtenção do título de Doutor em Ciências, Área de Concentração: Entomologia.

P I R A C I C A B A

Estado de São Paulo - Brasil

Fevereiro - 1996 
Dados Internacionais de Catalogação na Publicação (CIP)

DIVISÃo DE BIBLIOTECA E DOCUMENTAÇẤO - Campus "Luiz de Queiroz"/USP

Komatsu, Sônia Shigueyo

Caracterização fisico-química de méis de Apis mellifera L., 1758

(Hymenoptera: Apidae) de diferentes municípios do Estado de São Paulo / Sônia

Shigueyo Komatsu. - - Piracicaba, 1996.

90p. : il.

Tese (doutorado) - - Escola Superior de Agricultura Luiz de Queiroz, 1996. Bibliografia.

1. Mel - Caracterização fisico-química - São Paulo (Estado) I. Título

CDD $\quad 638.16$ 


\title{
CARACTERIZAÇÃO FÍSICO-QUÍMICA DE MÉIS \\ DE Apis mellifera L., 1758 (HYMENOPTERA: APIDAE) DE DIFERENTES MUNICÍPIOS DO ESTADO DE SÃO PAULO
}

\author{
SÔNIA SHIGUEYO KOMATSU
}

Aprovada em: 03/04/1996

Comissão julgadora:

Prof. Dr. Luís Carlos Marchini

Prof. Dr. Marco Antonio Azeredo Cesar

Prof. Dr. Rael Vidal

Profa ${ }^{a}$. Dra. Regina Helena Nogueira Couto

Dra. Augusta Carolina de C. C. Moreti
ESALQ-USP

ESALQ-USP

FZEA-USP

FCAVJ-UNESP

IZ-CPA-SAA 
Aos meus pais

Chikara e Yoko

Com amor e gratidão

OFEREÇO

À minha avó Tomi

À minha irmã Yurika

DEDICO 
Ao Prof. Luis Carlos Marchini, cuja orientação tornou possivel a realização deste trabalho,

meu especial agradecimento 


\section{AGRADECIMENTOS}

Aos professores do Departamento de Entomologia / ESALQ-USP, Dr. Celso Omoto, Dr. Evoneo Berti Filho, Dr. Gilberto Casadei de Batista, Dr. João Roberto Spotti Lopes, Dr. José Djair Vendramim, Dr. José Roberto Postali Parra, Dr. Luís Carlos Marchini, Dra. Marinéia de Lara Haddad, Dr. Octávio Nakano, Dr. Roberto Antonio Zucchi, Dr. Sinval Silveira Neto, pelos ensinamentos transmitidos.

Aos colegas e amigos do Curso de Pós-graduação em Entomologia, em especial, Edmilson J. Marques, Irene R. Marques, José Wellington de Morais, Francisco Deoclécio G. Paulino, Renato J. Arleu, André L. Lourenção, Laila H. Mihsfeldt, Fabíola M. Döbele, Geraldo Papa, Marcos Ap. Pizano, Leonardo L. Baumgratz, Carlos Alfredo L. de Carvalho, Sônia M. Torrecillas, Reginaldo Barros, Teresinha A. Giustolin, pelo companheirismo.

Ao Eng $^{0}$ Agr $^{0}$ e colega de curso Valmir Antonio Costa pela amizade, sugestões e colaboração constante durante o curso.

Ao Eng ${ }^{0}$ Químico Dr. Roberto Machado de Moraes, do Instituto de Tecnologia de Alimentos - ITAL (Campinas/SP), pela orientação durante o estágio realizado.

Aos professores Dr. João Gustavo Brasil Caruso e Dr. Marco Antonio Azeredo Cesar, do Departamento de Ciência e Tecnologia Agroindustrial, Setor Açúcar e Álcool, da ESALQ/USP, pela grande dedicação e orientação prestadas.

À Eng ${ }^{\circ}$ Agr $^{0}$ Dra. Augusta Carolina de C. C. Moreti, do Instituto de Zootecnia (Nova Odessa/SP), pelo apoio e colaboração.

Ao Eng ${ }^{\circ}$ Agr $^{0}$ Dr. Ronaldo M.B. da Silva e Biól. Dra. Etelvina C.A. da Silva, do Centro de Apicultura Tropical-IZ (Pindamonhangaba/SP), pela realização do estágio.

Ao Químico Sr. Odair Pessotti e laboratoristas Leda A. Nazareth e Maria Aparecida Godoy do Laboratório do Centro de Apicultura Tropical-IZ (Pindamonhangaba/SP), pelas instruções durante estágio realizado. 
Ao Técnico em Química Luis Roberto Boscariol, pelo apoio, instruções e assistência prestados.

À Prof Lídia M. R. C. Barreto, da Universidade de Taubaté-UNITAU, pela valiosa colaboração na aquisição das amostras de méis do Vale do Paraíba.

Ao Eng ${ }^{0}$ Químico Marcelo Carraro Martines, pela colaboração na aquisição das amostras de méis do litoral.

À Eng ${ }^{\circ}$ Agr $^{0}$ Dra. Marinéia de Lara Haddad pela orientação nas análises estatísticas.

Ao professor Dr. Celso Omoto pela elaboração do "summary".

À secretária Cibele M. Galvani do Departamento de Entomologia, pela assistência durante o curso.

Aos Sr(a). Armando Longatti, Oswaldo Bueloni, Antonio Sabino, Cícera Sabino, Francisco B. Castilho, Heraldo N. de Oliveira, João A. Cerignoni, João J. Forti, José C. R. Castilho, José Ventura Filho, Manoel de Araújo, funcionários do Departamento de Entomologia, pelo constante auxílio.

Aos Sr(a). Edson Maciel, Carlos E. Longatti, Sandra C. Longatti, Márcio V. Kupper (Lab. Toxicologia de Insetos); Solange A. Vieira (Lab. Patologia de Insetos); Neide G. Zerio (Lab. Biologia dos Insetos); Maria Edilene de Oliveira, Roselene Pereira (Lab. Controle Biológico de Insetos); Augusto C.P. Florin (Lab. Defensivos Agrícolas) do Departamento de Entomologia, pela inestimável contribuição nas atividades laboratoriais.

Ao estagiário Vanderlei D. A. dos Reis, do Laboratório de Apicultura, pelos auxílios prestados.

À Biól. Mayra. S. da Silva, pela valiosa colaboração durante seu estágio realizado no Laboratório de Apicultura do Departamento de Entomogia/ESALQ-USP.

Aos laboratoristas Sylvino L. Torrezan, Regina H. Gonçalves e Rosemary L.S. Mandro, do Laboratório do Departamento de Ciência e Tecnologia Agroindustrial, Setor Açúcar e Álcool, pela atenção dispensada durante o treinamento. 
Às bibliotecárias Eliana M. G. Sabino e Kátia M. A. Ferraz, pela orientação bibliográfica.

Ao Conselho Nacional de Desenvolvimento Científico e Tecnológico (CNPq), pela bolsa de estudos concedida.

A todos que, direta ou indiretamente, colaboraram na aquisição das amostras de mel e desenvolvimento da pesquisa. 


\section{SUMÁRIO}

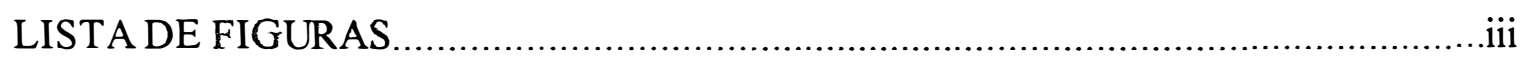

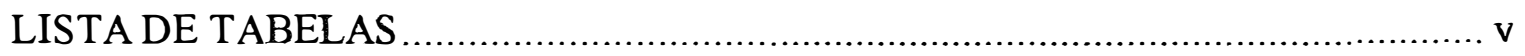

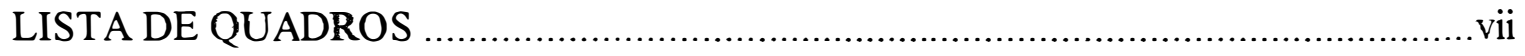

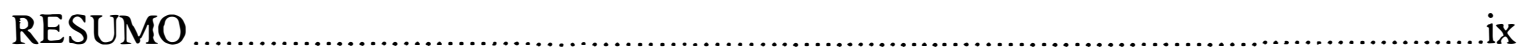

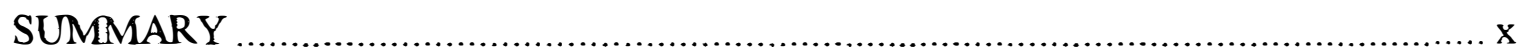

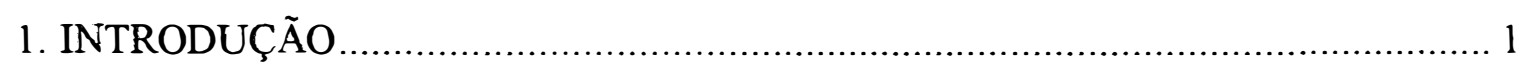

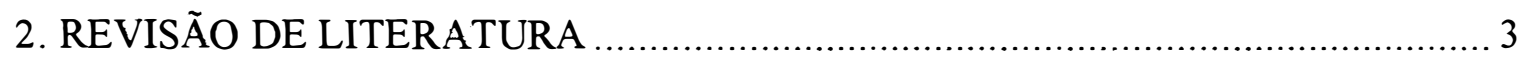

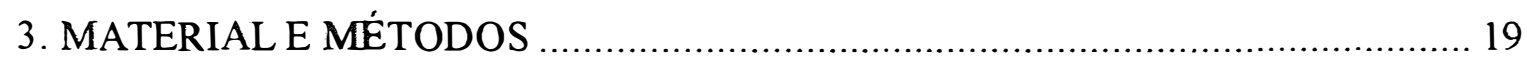

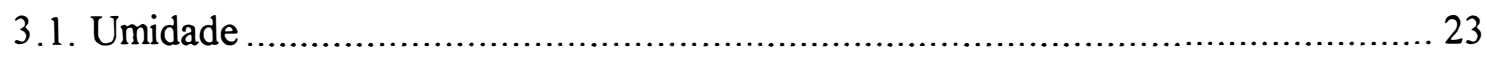

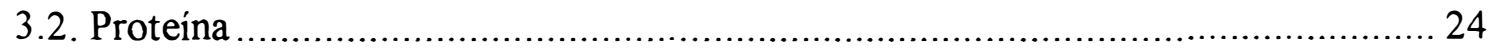

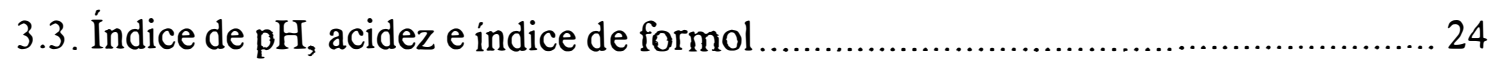

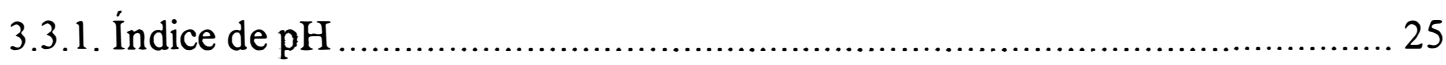

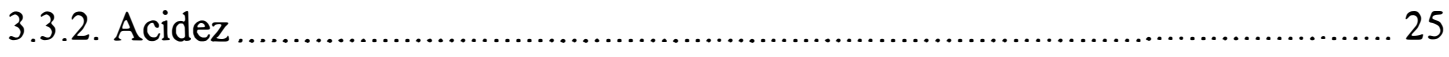

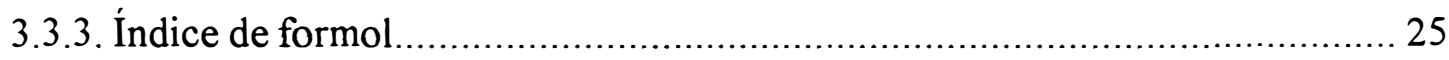

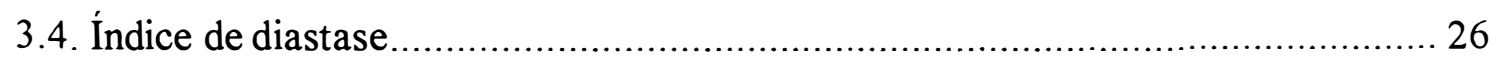

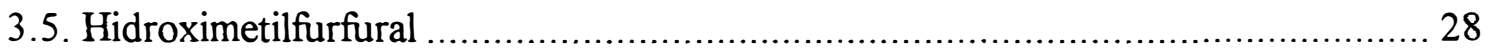

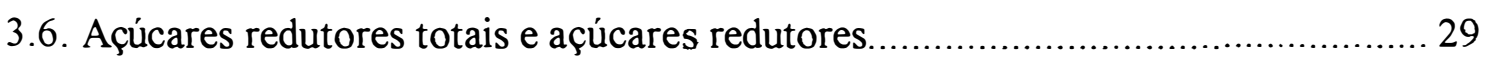

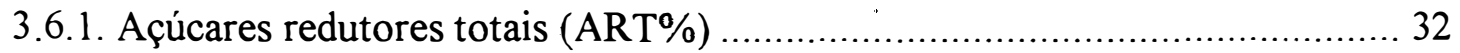

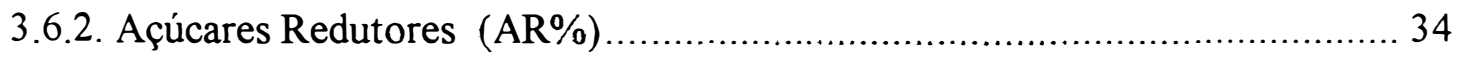

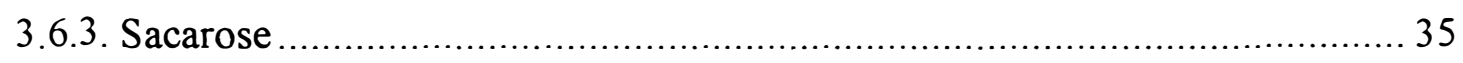

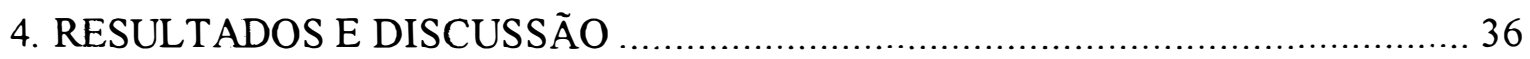

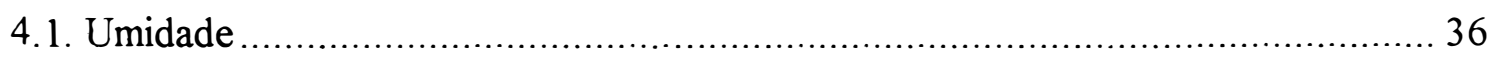

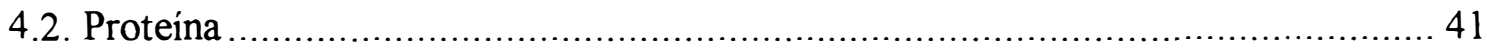




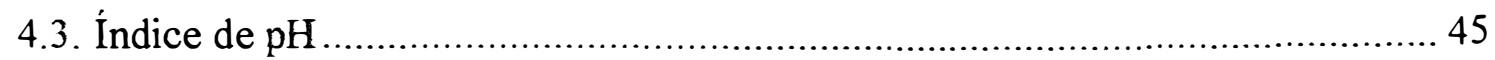

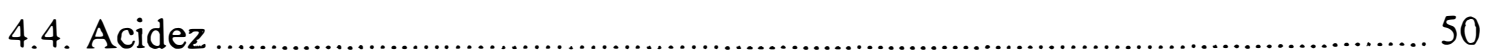

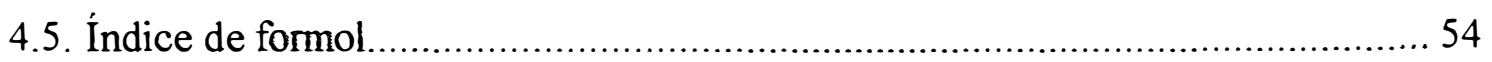

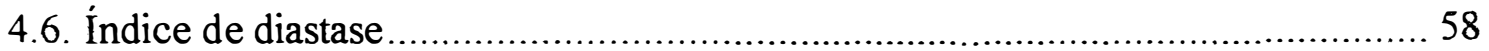

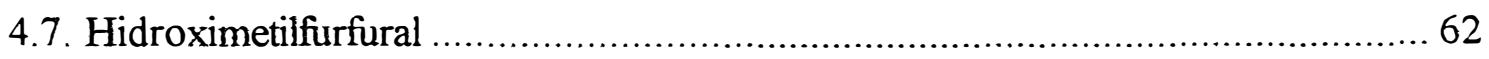

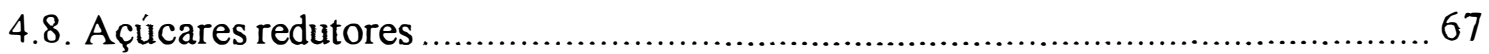

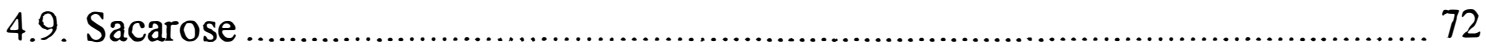

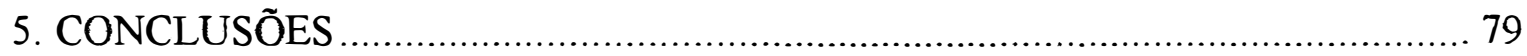

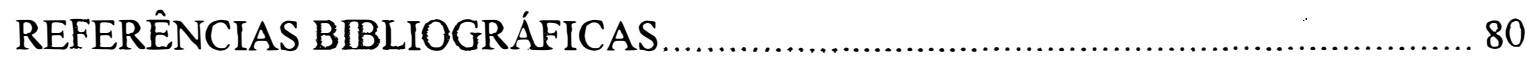




\section{LISTA DE FIGURAS}

Figura 1. Municípios paulistas e respectivas amostras estudadas (A), amostras de méis de flores silvestres (B), de eucalipto (C), de laranjeira (D) e de "méis" de exsudato de cana-de-açúcar (E).

Figura 2. Porcentagens do conjunto de todas as amostras estudadas (A), de méis de flores silvestres (B), de eucalipto (C), de laranjeira (D) e de "méis" de exsudato de cana-de-açúcar (E), que são ou não aceitáveis segundo especificações da legislação brasileira para umidade 40

Figura 3. Porcentagens do conjunto de todas as amostras estudadas (A), de méis de flores silvestres (B), de eucalipto (C), de laranjeira (D) e de "méis" de exsudato de cana-de-açúcar (E) que são ou não aceitáveis segundo especificações da legislação brasileira para proteína.

Figura 4. Porcentagens do conjunto de todas as amostras estudadas (A), de méis de flores silvestres (B), de eucalipto (C), de laranjeira (D) e de "méis" de exsudato de cana-de-açúcar (E), que são ou não aceitável segundo especificações da legislação brasileira para $\mathrm{pH}$. 49

Figura 5. Porcentagens do conjunto de todas as amostras estudadas (A), de méis de flores silvestres (B), de eucalipto (C), de laranjeira (D) e de "méis" de exsudato de cana-de-açúcar (E), que são ou não aceitáveis segundo especificações da legislação brasileira para acidez. 53

Figura 6. Porcentagens do conjunto de todas as amostras estudadas (A), de méis de flores silvestres (B), de eucalipto (C), de laranjeira (D) e de "méis" de exsudato de cana-de-açúcar $(E)$ que são ou não aceitáveis segundo especificações da legislação brasileira para índice de formol. 
Figura 7. Porcentagens do conjunto de todas as amostras estudadas (A), de méis de flores silvestres (B), de eucalipto (C), de laranjeira (D) e de "méis" de exsudato de cana-de-açúcar (E), que são ou não aceitáveis segundo especificações da legislação brasileira para índice de diastase. 61

Figura 8. Porcentagens do conjunto de todas as amostras estudadas (A), de méis de flores silvestres (B), de eucalipto (C), de laranjeira (D) e de "méis" de exsudato de cana-de-açúcar (E), que são ou não aceitáveis segundo especificações da legislação brasileira para HMF. 65

Figura 9. Porcentagens do conjunto de todas as amostras estudadas (A), de méis de flores silvestres (B), de eucalipto (C), de laranjeira (D) e de "méis" de exsudato de cana-de-açúcar (E), que são ou não aceitáveis segundo especificações da legislação brasileira para açúcares redutores. 71

Figura 10. Porcentagens do conjunto de todas as amostras estudadas (A), de méis de flores silvestres (B), de eucalipto (C), de laranjeira (D) e de "méis' de exsudato de cana-de-açúcar $(E)$, que são ou não aceitáveis segundo especificações da legislação brasileira para sacarose. 


\section{LISTA DE TABELAS}

Tabela 1. Especificações estabelecidas pela legislação brasileira para parâmetros determinados na análise de mel. 20

Tabela 2. Quantidades (ml) de água destilada, solução de mel e solução (amido $+\mathrm{NaCl}+$ ác. acético) a serem colocadas em cada um dos dez tubos de ensaio.

Tabela 3. Índice de diastase (ID) correspondente a cada tubo. 27

Tabela 4. Valores médios de umidade $(\overline{\mathrm{m}})$, desvio padrão da média $(\mathrm{s}(\overline{\mathrm{m}}))$, intervalo de variação (i.v.) e número (n) de amostras de méis de flores silvestres, de eucalipto, de laranjeira e de "méis" de exsudato de cana-de-açúcar coletadas em municípios do Estado de São Paulo.

Tabela 5 . Valores médios de proteína $(\overline{\mathrm{m}})$, desvio padrão da média $(\mathrm{s}(\overline{\mathrm{m}}))$, intervalo de variação (i.v.) e número(n) de amostras de méis de flores silvestres, de eucalipto, de laranjeira e de "méis" de exsudato de cana-de-açúcar coletadas em municípios do Estado de São Paulo.

Tabela 6. Valores médios de $\mathrm{pH}(\overline{\mathrm{m}})$, desvio padrão da média $(\mathrm{s}(\overline{\mathrm{m}}))$, intervalo de variação (i.v.) e número (n) de amostras de méis de flores silvestres, de eucalipto, de laranjeira e de "méis" de exsudato de cana-de-açúcar coletadas em municípios do Estado de São Paulo.

Tabela 7. Valores médios de acidez $(\overline{\mathrm{m}})$, desvio padrão da média $(\mathrm{s}(\overline{\mathrm{m}}))$, intervalo de variação (i.v.) e número (n) de amostras de méis de flores silvestres, de eucalipto, de laranjeira e de "méis" de exsudato de cana-de-açúcar coletadas em municípios do Estado de São Paulo. 
Tabela 8. Valores médios de índice de formol $(\overline{\mathrm{m}})$, desvio padrão da média $(\mathrm{s}(\overline{\mathrm{m}}))$, intervalo de variação (i.v.) e número (n) de amostras de méis de flores silvestres, de eucalipto, de laranjeira e de "méis" de exsudato de cana-de-açúcar coletadas em municípios do Estado de São Paulo. 56

Tabela 9. Valores médios de índice de diastase $(\overline{\mathrm{m}})$, desvio padrão da média $(\mathrm{s}(\overline{\mathrm{m}}))$, intervalo de variação (i.v.) e número (n) de amostras de méis de flores silvestres, de eucalipto, de laranjeira e "méis" de exsudato de cana-de-açúcar coletadas em municípios do Estado de São Paulo

Tabela 10. Valores médios de HMF $(\overline{\mathrm{m}})$, desvio padrão da média $(\mathrm{s}(\overline{\mathrm{m}}))$, intervalo de variação (i.v.) e número (n) de amostras de méis de flores silvestres, de eucalipto, de laranjeira e de "méis" de exsudato de cana-de-açúcar coletadas em municípios do Estado de São Paulo. 64

Tabela 11. Valores médios de açúcares redutores $(\overline{\mathrm{m}})$, expresso em glicose, desvio padrão da média $(\mathrm{s}(\overline{\mathrm{m}}))$, intervalo de variação (i.v.) e número (n) de amostras de méis de flores silvestres, de eucalipto, de laranjeira e de "méis" de exsudato de cana-de-açúcar coletadas em municípios do Estado de São Paulo.

Tabela 12. Valores médios de sacarose $(\overline{\mathrm{m}})$, desvio padrão da média $(\mathrm{s}(\overline{\mathrm{m}}))$, intervalo de variação (i.v.) e número (n) de amostras de méis de flores silvestres, de eucalipto, de laranjeira e de "méis" de exsudato de cana-de-açúcar coletadas em municípios do Estado de São Paulo. 74

Tabela 13. Valores médios de açúcares redutores totais $(\overline{\mathrm{m}})$, desvio padrão da média $(s(\bar{m}))$, intervalo de variação (i.v.) e número (n) de amostras de méis de flores silvestres, de eucalipto, de laranjeira e de "méis" de exsudato de cana-de-açúcar coletadas em municípios do Estado de São Paulo. 78 


\section{LISTA DE QUADROS}

Quadro I. Número de amostras de méis de flores silvestres (S), de eucalipto (E), de laranjeira (L) e de "méis" de exsudato de cana-de-açúcar (C) coletadas nos diferentes municípios do Estado de São Paulo.

Quadro II. Valores médios de umidade (\%) das amostras de méis de flores silvestres, de eucalipto, de laranjeira e de "méis" de exsudato de cana-de-açúcar coletadas em municípios do Estado de São Paulo.

Quadro III. Valores de proteina $(\mathrm{ml})$ das amostras de méis de flores silvestres, de eucalipto, de laranjeira e de "méis" de exsudato de cana-de-açúcar coletadas em municípios do Estado de São Paulo.

Quadro IV. Valores de pH das amostras de méis de flores silvestres, de eucalipto, de laranjeira e de "méis" de exsudato de cana-de-açúcar coletadas em municípios do Estado de São Paulo. 46

Quadro V. Valores de acidez (meq/kg) das amostras de méis de flores silvestres, de eucalipto, de laranjeira e de "méis" de exsudato de cana-de-açúcar coletadas em municípios do Estado de São Paulo

Quadro VI. Valores de indice de formol $(\mathrm{ml} / \mathrm{kg})$ das amostras de méis de flores silvestres, de eucalipto, de laranjeira e de "méis" de exsudato de cana-de-açúcar coletadas em municípios do Estado de São Paulo 55

Quadro VII. Valores de índice de diastase das amostras de méis de flores silvestres, de eucalipto, de laranjeira e de "méis" de exsudato de cana-de-açúcar coletadas em municípios do Estado de São Paulo.

Quadro VIII. Valores de HMF $(\mathrm{mg} / \mathrm{kg}$ ) das amostras de méis de flores silvestres, de eucalipto, de laranjeira e de "méis" de exsudato de cana-de-açúcar coletadas em municípios do Estado de São Paulo 
Quadro IX. Valores de açúcares redutores (\%), expressos em glicose, das amostras de méis de flores silvestres, de eucalipto, de laranjeira e de "méis" de exsudato de cana-de-açúcar coletadas em municípios do Estado de São Paulo. 68

Quadro X. Valores de sacarose (\%) das amostras de méis de flores silvestres, de eucalipto, de laranjeira e de "méis" de exsudato de cana-de-açúcar coletadas em municípios do Estado de São Paulo. 73

Quadro XI. Valores de açúcares redutores totais (\%), expressos em glicose, das amostras de méis de flores silvestres, de eucalipto, de laranjeira e de "méis" de exsudato de cana-de-açúcar coletadas em municipios do Estado de São Paulo. 


\title{
CARACTERIZAÇÃO FÍSICO-QUÍMICA DE MÉIS \\ DE Apis mellifera L., 1758 (HYMENOPTERA: APIDAE) DE \\ DIFERENTES MUNICÍPIOS DO ESTADO DE SÃO PAULO
}

\author{
Autora: SÔNIA SHIGUEYO KOMATSU \\ Orientador: PROF. DR. LUÍS CARLOS MARCHINI
}

\section{RESUMO}

Estudo sobre caracterização de méis, de noventa e sete municípios do Estado de São Paulo, produzidos por Apis mellifera, foi realizado no Laboratório de Apicultura do Departamento de Entomologia da Escola Superior de Agricultura "Luiz de Queiroz", USP/Campus-Piracicaba, no período de 1994-1995.

Foram analisadas cento e sessenta amostras, das quais 94 de méis de flores silvestres, 27 de flores de eucalipto, 34 de flores de laranjeira e 5 amostras de "méis" de exsudato de cana-de-açúcar.

De acordo com os dados obtidos, foi concluído que a caracterização das amostras estudadas do presente trabalho é estabelecida por faixas de variação de valores obtidas para cada parâmetro considerado: 16,0 a 23,4\% para umidade; 0,0 a 1,6 ml para proteína; 2,3 a 5,1 para pH; 12,5 a $75,5 \mathrm{meq} / \mathrm{kg}$ para acidez; 5,0 a $21,5 \mathrm{ml} / \mathrm{kg}$ para índice de formol; 5,0 a 38,5 para índice de diastase; 0,3 a $242,6 \mathrm{mg} / \mathrm{kg}$ para HMF; 53,2 a $80,0 \%$ para açúcares redutores e 0,1 a 27,4 para sacarose.

As porcentagens de amostras que se enquadram nas especificações da legislação brasileira para qualidade de mel para cada parâmetro estudado foram: $83,8 \%$ para umidade; 40,6\% para proteína; 44,4\% para $\mathrm{pH} ; 80,0 \%$ para acidez; $94,4 \%$ para índice de formol; 93,7\% para índice de diastase; $95,0 \%$ para HMF; $65,0 \%$ para açúcares redutores e $98,1 \%$ para sacarose. 


\title{
PHYSICO-CHEMICAL CHARACTERIZATION OF HONEYS OF Apis mellifera L., 1758 (HYMENOPTERA: APIDAE) FROM VARIOUS LOCATIONS IN THE STATE OF SÃO PAULO
}

\author{
Author: SÔNIA SHIGUEYO KOMATSU \\ Adviser: PROF. DR. LUIS CARLOS MARCHINI
}

\section{SUMMARY}

Characterization of honeys of Apis mellifera collected from 97 locations in the State of São Paulo was conducted at Apiculture Laboratory of Department of Entomology, Escola Superior de Agricultura "Luiz de Queiroz", University of São Paulo, Piracicaba-SP, during the period from 1994 to 1995. A total of 160 honey samples were analyzed: 94 from wild flowers, 27 from Eucaliptus flowers, 34 from Citrus flowers, and 5 from sugarcane exsudates.

According to the results, the characterization of honeys was established by ranges for each parameter studied: 16.0 to $23.4 \%$ for moisture content, 0.0 to $1.6 \mathrm{ml}$ for protein content, 2.3 to 5.1 for $\mathrm{pH}, 12.5$ to $75.5 \mathrm{meq} / \mathrm{kg}$ for acidity, 5.0 to $21.5 \mathrm{ml} / \mathrm{kg}$ for formol number, 5.0 to 38.5 for diastase number, 0.3 to $242.6 \mathrm{mg} / \mathrm{kg}$ for $\mathrm{HMF}, 53.2$ to $80.0 \%$ for ), reducing sugars and 0.1 to $27.4 \%$ for sucrose.

In this study, the percentage of honey samples that followed the Brazilian legislation for honey quality for each parameter evaluated were: $83,8 \%$ for moisture content, $40.6 \%$ for protein content, $44.4 \%$ for $\mathrm{pH}, 80.0 \%$ for acidity, $94.4 \%$ for formol number, $93,7 \%$ for diastase number, $95,0 \%$ for $\mathrm{HMF}, 65.0 \%$ for reducing sugars and $98.1 \%$ for sucrose. 


\section{INTRODUÇÃO}

O mel é um produto genuinamente natural e há milênios vem sendo utilizado como alimento pela humanidade. Além do seu valor nutritivo, apresenta funções terapêuticas e, também, é utilizado largamente pela indústria de cosméticos.

Existem méis de diferentes origens. Méis de origem floral são os mais comumente divulgados e comercializados, tais como: méis de flores de eucalipto, de flores de laranjeira, de flores silvestres, etc. Já, os "méis" de origem não floral, como é o caso dos "méis" de exsudato de cana-de-açúcar, após a queima da cultura, são menos apreciados e até rejeitados pelos consumidores.

No Brasil, onde o mel ainda não é rotineiramente consumido, por falta de hábito, não existe um padrão que expresse sua qualidade baseando-se em características químicas ou fisicas. Por esse motivo, até hoje, segue-se, por exemplo, o padrão estabelecido pelos norte-americanos, e que são adotados pela legislação brasileira.

A flora apícola brasileira é bastante diversificada, variando de região para região. Assim sendo, tornam-se necessárias uma caracterização e posteriormente a criação de padrões de tais méis de acordo com os fatores vegetais, edáficos e climáticos das respectivas regiões em que são produzidos.

Para o Estado de São Paulo que possui um número expressivo de apicultores e uma população consumidora de mel de grande potencial, uma caracterização e padronização coerentes com suas condições ambientais seriam de grande importância, não só para melhorar a qualidade do mel aqui produzido, como dar garantias do produto ao consumidor.

Essa caraterização do mel pode ser realizada através de diversos métodos. A análise química ou fisica, conforme o parâmetro considerado, é convencionalmente empregada.

Diante dessa escassez de informações tão necessárias para incrementar a apicultura nacional, e especialmente a paulista, o presente trabalho tem por objetivo a caracterização de diferentes méis produzidos por Apis mellifera L., 1758, a partir de 
diversas plantas apícolas de vários municípios do Estado de São Paulo, o estabelecimento de faixas de variação dos valores para cada parâmetro e as porcentagens de méis enquadradas nas especificações da legislação brasileira. 


\section{REVISÃO DE LITERATURA}

$\mathrm{Na}$ literatura é notável o número de trabalhos científicos empregando métodos químicos e fisicos na análise dos diferentes parâmetros, que caracterizam os méis. Pesquisadores, dedicados à apicultura, fazem dos méis de várias regiões de muitos países objeto de seus estudos; assim, são freqüentes os trabalhos referentes a méis produzidos na Índia (Narayama, 1970), Taiwan (Lin et al., 1977), Egito (El-Sherbiny et al., 1980), Itália (Butta et al., 1983; Spettoli, 1983), Turquia (Temiz, 1983), Rússia (Ivanov \& Chervenakova, 1984), Fiji (Poncini et al., 1984), Japão (Hase \& Aida, 1986), Grécia (Thrasyvoulou, 1986), Arábia Saudita (Mesallan \& El Shaarawy, 1987), Venezuela (Vit-Oliver, 1988), Brasil ( Flechtmann et al., 1963; Vidal \& Fregosi, 1984; Almeida \& Marchini, 1986; Moraes et al., 1989), e em outros países.

São encontrados trabalhos que comparam diferentes métodos de análise de mel, outros que modificam os métodos convencionais, e aqueles que apresentam novas técnicas. Entretanto, a grande maioria visa os resultados das determinações que, então, são comparados com o padrão ditado por órgãos oficiais internacionais, ou com o estabelecido pelo próprio país.

Nesse sentido, é claramente observada a preocupação de certos países em não só manter a qualidade do mel produzido, como fiscalizar, também, os méis importados com relação a sua adulteração.

A respeito dos parâmetros considerados na presente pesquisa destaca-se que a umidade é uma das determinações realizadas visando sua caracterização; sendo que o teor de água no mel tem grande importância, por exemplo, ao que se refere à sua cristalização e maturidade (Stonoga \& Freitas, 1991).

Apesar do pouco conhecimento sobre as características do material protéico, a ocorrência de proteína em mel é utilizada na detecção de adulteração de mel comercial (Crane, 1975).

$\mathrm{O} \mathrm{pH}$, também, é determinado nessas análises e refere-se aos ions hidrogênio presentes numa solução de mel (Vidal \& Fregosi, 1984). 
O mel possui uma boa quantidade de ácidos, principalmente o glucônico. Os valores dessa acidez permitem detectar o processo de fermentação, comum em méis (Cornejo, 1988).

Índice de diastase refere-se à diastase, nome comum da enzima alfaamilase, que tem por função digerir o amido; sua origem, mais aceita atualmente, é atribuída a uma secreção salivar das abelhas. Esse parâmetro indicado para avaliar a qualidade do mel por Gothe', citado por White (1994), dá indicações sobre superaquecimento, o que compromete seriamente o produto.

O hidroximetilfurfural (HMF) é produto da desidratação de açúcares, produzido quando o mel é aquecido; também pode ser formado durante o armazenamento. É um parâmetro que além do superaquecimento também indica a idade do mel (Salinas et al., 1991).

Os açúcares redutores, glicose e frutose, são carboidratos do grupo dos monossacarídeos. São substâncias com capacidade de reduzir íons de cobre em solução alcalina (Vidal \& Fregosi, 1984).

A sacarose é um açúcar não redutor pertencente ao grupo dos oligossacarídeos, e que é passível de hidrólise através de ácidos diluídos ou enzimas (invertase), resultando em dois monossacarídeos, frutose e glicose (Vidal \& Fregosi, 1984).

Trabalhos científicos, cujos autores estudaram os mesmos parâmetros anteriormente citados, serão relacionados a seguir.

Diante da variável flora apícola do Estado de São Paulo e sua influência nas propriedades do mel, Flechtmann et al. (1963) analisaram amostras de méis de flores de eucalipto, de laranjeira e de outras espécies melíferas dos municípios Suzano, Pindamonhangaba, Guaratinguetá, Agudos, Bebedouro, Urupês e Aguaí. Nas 17 amostras de méis, além de cor e porcentagem de cinzas, os autores determinaram umidade, $\mathrm{pH}$ e açúcares, obtendo valores variando de $15,0-19,3 \% ; 2,3-4,4$; e 80,02$83,80 \%$, respectivamente; não observando correlação entre os parâmetros estudados.

Phadke (1967), após determinar o conteúdo de água em amostras de méis indianos, verificou que, em geral, as amostras com os maiores conteúdos de água e maior

'GOTHE, F. Die Fermenti des Honigs. Zeitschrift für Untersuchunug der Nahrungund Genussmittel, v.28, n.6, p. 273-86, 1914. 
acidez apresentavam baixo conteúdo de frutose e glicose/frutose em comparação aos méis importados pela Índia.

No Brasil, Cornejo \& Tomasevich (1970) determinaram valores de 17,6 a $20,8 \%$ de umidade para amostras de méis produzidas no Estado do Rio Grande do Sul e Santa Catarina.

Wootton \& Ryall (1985) apresentaram a análise de HMF de 20 amostras de méis, com a finalidade de comparar o método HPLC com o da "Codex Alimentarius Commission" (1969). Não constataram diferenças significativas nós níveis de HMF determinados, nem na reprodutibilidade entre os dois métodos. Já, com méis aquecidos o método da "Codex" apresentou valores mais altos. Esses autores encontraram valores exageradamente altos de HMF para uma mesma amostra analisada pelos referidos métodos, $122 \mathrm{mg} / \mathrm{kg}$ pelo HPLC e $241 \mathrm{mg} / \mathrm{kg}$ pela "Codex Alimentarius Commission". Para fins de análise estatística os autores não consideraram a amostra com esse dado discrepante, justificando que esse alto valor de HMF e a cor escura do mel indicavam danos devido ao aquecimento.

Lin et al. (1977) detectaram em 30 amostras de méis produzidas em Taiwan um conteúdo de água da ordem de 66 a 74\%. Entretanto, a maioria dos autores apresentaram valores médios de: 20,9\% (Phadke, 1967); 20-24\% (Lin et al., 1977); 18,5\% (Mahajan, 1984); 18,9\% (Kohlich \& Krenn, 1985); 13-16\% (Faraji-Haremi \& Hosseini, 1987); 14-17\% (Hankin, 1987); 16,3-22,3 (Vorwohl et al., 1988); 15,2530,45\% (Kassaye \& Gardegaba 1989).

Natarajan \& Yesuvadian (1978) relataram que amostras de méis com alta umidade são comuns na Índia, citando como exemplo, que mais da metade das amostras de méis de Kerala e Tamilnadu apresentavam no mínimo $23 \%$ umidade.

White Jr. (1980) relatou que o teste de Fiehe diferencia objetivamente o mel aquecido ou armazenado do mel misturado com açúcar invertido. Segundo o autor, quatro laboratórios no período de 1960 e 1974, publicaram dados de 1728 determinações de HMF em méis comerciais, apresentando um conteúdo médio de $1,24 \mathrm{mg} / 100 \mathrm{~g}$. $\mathrm{O}$ autor também salientou a existência de padrões de qualidade europeus que permitem um máximo de $4 \mathrm{mg} / \mathrm{l} 00 \mathrm{~g}$ para HMF.

Dozo (1980) relatou que 4,5\% das 66 amostras de méis, de diferentes localidades de Buenos Aires, apresentaram teor de sacarose entre 5 e $8 \%$, somente 1,5\% das amostras apresentaram valor maior que $8 \%$ e, $94 \%$ apresentaram valor menor que $5 \%$. 
El-Sherbiny et al. (1980) a nalisaram 10 amostras de méis egípcios de Citrus, encontrando valores médios de umidade, $17,5 \%$, açúcares redutores, $75,3 \%$ e sacarose, 3,6\%. Os autores também analisaram as amostras com relação à diastase e indicaram que os méis tinham sido submetidos a superaquecimento.

Salashinskii et al. (1980), correlacionaram a alta umidade das amostras de méis com um alto conteúdo de sacarose e glicose, e também, com um baixo conteúdo de açúcares redutores.

Thrasyvoulou et al. (1982) apresentaram as porcentagens de 41 amostras de méis gregos comerciais que se enquadravam nos limites permitidos pelos padrões europeus, assim, 45\% estavam fora dos limites permitidos para açúcares redutores e sacarose e, $18 \%$ não se enquadravam nos limites permitidos para HMF.

Butta et al. (1983) com o objetivo de verificar se as amostras de méis nacionais e estrangeiros comercializadas em Milão correspondiam às normas vigentes, determinaram a umidade, acidez e HMF em 35 amostras de méis de diferentes floradas. Os autores concluíram que para: a) umidade, 2 amostras de méis (6\% das amostras) apresentaram valores superiores a $21 \%$, b) acidez, 4 amostras de méis $(11 \%$ das amostras) com valores maiores que $40 \mathrm{meq} / \mathrm{kg} \mathrm{e} \mathrm{c)} \mathrm{HMF,} 8$ amostras de méis $(23 \%$ das amostras) superaram o limite de $40 \mathrm{mg} / \mathrm{kg}$. Os valores médios apresentados para os parâmetros foram: umidade (18,15\%), acidez $(25,60 \mathrm{meq} / \mathrm{kg})$ e HMF $(37,42 \mathrm{mg} / \mathrm{kg})$.

Nauta (1983) em seu trabalho relatou que o mel é constituído predominantemente de uma solução aquosa de dois monossacarídeos, frutose e glicose, com uma proporção de água de aproximadamente 17-20\%. Para a concentração de frutose e glicose, tem-se os valores de $41 \%$ e $34 \%$, respectivamente. A lei prevê um teor aparente de açúcares redutores não inferior a $65 \%$ para mel floral e não inferior a $60 \%$ para "mel" não floral. O conteúdo de sacarose não deve ser superior a 5\% (para "mel" de "honeydew") e 10\% para outros méis (acácia, lavanda, Banksia menziesii). A acidez máxima permitida é de $40 \mathrm{meq} / \mathrm{kg}$. O índice de diastase deve ser no mínimo 8 (3 se o teor de $\mathrm{HMF}<15 \mathrm{mg} / \mathrm{kg}$ ) e o $\mathrm{HMF}$ deve ser inferior a $40 \mathrm{mg} / \mathrm{kg}$.

Piazza \& Accorti (1983) também apresentaram, em termos de porcentagem, o número de amostras de méis que se enquadrava nos limites estabelecidos pela EEC para HMF. Assim, 100\% das 146 amostras de méis adquiridas de pequenos apicultores da Itália, $97 \%$ das 156 amostras de méis adquiridas em cooperativas, $76 \%$ das 148 amostras de méis italianos vendidas no comércio e $55 \%$ das 64 amostras de méis 
importados vendidas na Itália estavam de acordo com as especificações oficiais permitidas (máximo $40 \mathrm{mg} / \mathrm{kg}$ ).

Poncini \& Wimmer (1983) analisaram 6 amostras de méis produzidas em "Fiji", obtendo os seguintes valores: umidade, 16,3-18,5\%; açúcares redutores, 61,6$71,3 \%$; sacarose, $0,6-6,4 \%$; $\mathrm{pH}, 3,77-4,01$.

Spettoli et al. (1983) avaliaram algumas das características fisicas e químicas de amostras de méis produzidas nas áreas de "East Friuli". Determinaram, entre outros parâmetros, a umidade, $\mathrm{pH}$, acidez, HMF, açúcares redutores e sacarose em 9 amostras de méis, das seguintes floradas: Fagopyrum esculentum, multiflorais, Phacelia tanacetifolia, Tilia sp., Robinia pseudoacacia, Castanea sativa. Os valores de umidade variaram de 15,7 a $18,6 \%$; os de $\mathrm{pH}$, de 3,73 a 4,73; os de acidez, de 10,7 a 33,5 meq/kg; os de HMF, de 0,5 a $24,9 \mathrm{mg} / \mathrm{kg}$; os de açúcares redutores, de 68,4 a $75,7 \%$; e os de sacarose, de 0,67 a $4,83 \%$. Com base nos resultados obtidos, as amostras de méis analisadas foram consideradas de boa qualidade.

Temiz (1983) estudou 47 amostras de méis produzidas na região de Izmir, Turquia, dentre as quais, 10 eram de Citrus. Amostras de méis recém-colhidas apresentaram, na análise de diversos parâmetros, os seguintes intervalos de variação: umidade, 14,69-16,26\%; açúcares redutores, 56,24-76,78\%; sacarose, 0,64-2,60\%; pH, 3,75-5,25; acidez, 13,4-33,9 meq/kg; índice de formol, 4,5-8,6 ml/kg; HMF, 1,65-4,15 $\mathrm{mg} / \mathrm{kg}$; indice de diastase, 19,31-48,15. A maioria dessas amostras, consideradas no estudo, enquadrou-se na faixa aceitável estabelecida para padrão europeu e da Turquia com relação a mel.

Archenti (1984) trabalhando com 32 amostras de méis da província de Chubut, Argentina, obteve uma média de $14,7 \%$ de umidade, $3,7 \%$ de sacarose e $0,18 \%$ de proteína.

Huidobro \& Simal (1984) utilizando a combinação dos métodos redutiométrico, gravimétrico e enzimático, determinaram em 91 amostras de méis da Galícia, Espanha, uma concentração de $62,9 \%$ de açúcares redutores e $11,0 \%$ de sacarose.

Lee (1984) estudou a interação proteína/ácido tânico do mel relacionado com a clarificação de suco de maçã através de mel, pois, o autor pressupõe que o componente responsável por essa clarificação seja a proteína. Para esse estudo o teor de proteína do mel foi determinado através de método fotométrico, utilizando-se reagente fenol Folin-Ciocalteus. 
Poncini et al. (1984) verificaram que todas as amostras analisadas apresentaram umidade variando de 14,9 a $18,4 \%$, valores estes que satisfizeram o padrão estabelecido pela "Codex Alimentarius Commission" como padrão europeu de mel.

Vidal \& Fregosi (1984) afirmaram que, além da temperatura, o pH do mel tem importância para a velocidade de formação de HMF.

Reio \& Englund (1985) analisaram 55 amostras de méis vendidas na Suiça, mas importadas de 14 diferentes países, a fim de verificar se estavam de acordo com os padrões da "Codex Alimentarius Commission". Encontraram um conteúdo de água variando de 16 a 20\%. Algumas amostras da Bulgária, Romênia, Cuba, Caribe, México e Estados Unidos (Califórnia), tinham HMF na faixa de 6,5 a $95,2 \mathrm{mg} / \mathrm{kg}$, estando o último valor acima do máximo permitido pela "Codex Alimentarius Commission" (40 mg/kg), indicando que o mel tinha sido aquecido ou armazenado por um longo tempo.

Para constatar a qualidade do mel italiano, segundo a legislação italiana, e, também fornecer mais informações para uma futura caracterização dos méis da Sardenha, Tuveri \& Prosperi (1985) analisaram 40 amostras de méis obtendo os seguintes resultados médios: 9 de eucalipto (umidade $=16,0 \%$; acidez=20,6 meq $/ \mathrm{kg}$; índice de diastase $=19,4 ; \mathrm{HMF}=23 \mathrm{mg} / \mathrm{kg}$; açúcares redutores $=75,73 \%$; sacarose $=1,37 \%$ ), $5 \mathrm{de}$ "agrumi" (umidade=16,69\%; acidez=18,6 meq $/ \mathrm{kg}$; indice de diastase=17,6; HMF=12,8 $\mathrm{mg} / \mathrm{kg}$; açúcares redutores $=74,18 \%$; sacarose $=1,57 \%), 5$ de "cardi spontanei" (umidade $=16,55 \%$; acidez=19,80 meq $/ \mathrm{kg}$; indice de diastase $=16,3 ; \mathrm{HMF}=15,2 \mathrm{mg} / \mathrm{kg}$; açúcares redutores=74,37\%), 3 de "asfodelo" (umidade=16,07\%; acidez=16,13 meq $/ \mathrm{kg}$; $\mathrm{HMF}=14,33 \mathrm{mg} / \mathrm{kg}$; açúcares redutores $=75,63 \%$, sacarose=1,04\%), 3 de "corbezzolo" (umidade $=15,72 \%$; acidez=33,7 meq $/ \mathrm{kg}$; índice de diastase=3,9; HMF=24,5 mg/kg; açúcares redutores $=73,88 \%$; sacarose $=1,67 \%$ ), 1 de lavanda (umidade $=14,44 \%$; acidez $=12,3 \mathrm{meq} / \mathrm{kg}$; indice de diastase $=10,9 ; \mathrm{HMF}=$ traços; açúcares redutores $=76,46 \%$; sacarose $=1,93 \%$ ) e 15 méis multiflorais (umidade $=16,70 \%$; acidez $=23,77 \mathrm{meq} / \mathrm{kg}$; índice de diastase=19,15; $\mathrm{HMF}=18,0 \mathrm{mg} / \mathrm{kg}$; açúcares redutores $=74,28 \%$; sacarose $=1,14 \%$ ).

Colin et al. (1986), analisando 67 amostras de méis comerciais compradas em várias localidades da França, quanto à umidade, açúcares, diastase e HMF, concluíram que $12 \%$ das amostras estavam abaixo dos padrões estabelecidos.

Almeida \& Marchini (1986) obtiveram o teor de proteina, em amostras de méis de diferentes origens florais, através da determinação da porcentagem de nitrogênio pelo método micro Kjedhal, utilizando $\mathrm{H}_{2} \mathrm{SO}_{4} 0,01 \mathrm{~N}$ na titulação, cujo valor obtido multiplicado pelo fator 6,25 resultou na porcentagem de proteina. Verificaram que a 
amostra de "mel" de cana diferiu estatisticamente das amostras de méis de eucalipto e de mata-pasto, a qual, por sua vez, diferiu das amostras de méis de laranja e de angico.

Amaral et al. (1986) determinaram a quantidade de proteína e açúcares totais de 16 amostras de méis produzidas em várias regiões do Estado de São Paulo, sendo 9 predominantemente de flores de eucalipto e 7 de laranjeira. Os valores médios obtidos para proteina e açúcares totais foram respectivamente $2,54 \%$ e $77,6 \%$ para méis de flores de eucalipto e $2,79 \%$ e $74,85 \%$ para méis de flores de laranjeira.

Moraes \& Mantovani (1986) trabalharam com amostras de méis de assapeixe, cipó-uva, abacate, Citrus, "méis" de cana e "méis" de cana carrapicho e eucalipto, visando a determinação da umidade, açúcares redutores e sacarose, entre outros parâmetros. Obtiveram, respectivamente, para os referidos parâmetros, os seguintes valores: méis de flores de assa-peixe $(17,00 \%, 79,57 \%$ e $1,71 \%)$, méis de flores de cipóuva $(18,40 \%, 71,9 \%$ e $0,92 \%)$, méis de flores de abacateiro $(17,20 \%, 65,08 \%$ e $0,55 \%)$, méis de flores de Citrus (15,60\%, 75,90\% e 1,85\%), "méis" de cana (16,60\%, 69,11\% e 1,87\%), "méis" de cana carrapicho e eucalipto (16,00\%, 67,23\% e 1,31\%).

Pfau \& Ruhle (1986) analisaram 19 amostras de méis paranaenses das regiões Norte Velho (1), Norte Novíssimo (3), Central (1), Sudoeste (3) e Sul (11) visando premiar um dos apicultores associados à FEPA (Federação Paranaense de Apicultores) que apresentasse o melhor mel produzido naquele Estado. Os valores obtidos na análise das amostras de méis do primeiro e segundo colocados no concurso, respectivamente, foram, umidade (17,6 e 18,6\%), $\mathrm{pH}(3,88$ e 3,84), acidez $(22,0$ e 14,0 $\mathrm{meq} / \mathrm{kg})$, índice de diastase (24,33 e 11,34 unidades), sólidos solúveis $(82,4$ e $81,4 \%)$.

Thrasyvoulou (1986) analisou o índice de diastase e HMF de 125 amostras de méis, dentre as quais, 20 florais, 20 de "Greek heather", 33 de "honeydew", 20 de Polygonum spp. e 32 de Thymus spp. O objetivo do trabalho foi estudar a ocorrência natural de HMF e diastase em méis gregos, e o efeito do armazenamento e aquecimento sobre tais parâmetros. $\mathrm{O}$ autor constatou que mel de Thymus spp. foi o único a apresentar HMF em todas as amostras, sendo, também, o de maior concentração de $\operatorname{HMF}(21,1$ $\mathrm{mg} / \mathrm{kg}$ ) e menor valor de índice de diastase (4,5 unidades). Também foram determinadas, para 4 amostras de méis florais e 4 de "méis" de honeydew, a umidade, $\mathrm{pH}$, acidez, açúcares redutores, e sacarose, além de HMF e índice de diastase. Segundo o autor, armazenamento e aquecimento causam diferentes taxas de perda de diastase e produção de HMF, mesmo em amostras de méis de mesma origem, o que complica ainda mais o uso desses parâmetros como critério para detectar superaquecimento de mel. 
De acordo com o artigo PUBLICATA una... (1987) num trabalho sobre caracterização visando a qualidade do mel italiano, foram analisadas 12 diferentes amostras de méis monoflorais, inclusive de flores de eucalipto. A partir dos resultados obtidos, para cada parâmetro, as amostras de méis de flores de eucalipto apresentaram, respectivamente, os seguintes valores médios e especificações sugeridas: umidade $(16,6 \% ;<18,0 \%), \mathrm{pH}(4,0 ; 3,7-4,2)$, acidez $(14,0 \mathrm{meq} / \mathrm{kg} ;<20 \mathrm{meq} / \mathrm{kg})$, indice de diastase $(14,0 ;>10$ unidades escala Gothe), HMF $(2,9 \mathrm{mg} / \mathrm{kg} ;<10 \mathrm{mg} / \mathrm{kg})$, açúcares redutores $(67,1 \% ; 58-73 \%)$ e sacarose $(0,59 \% ;<3 \%)$.

Bogdanov et al. (1987) trabalharam com 37 amostras de méis, entre suíços e importados, determinando, dentre os parâmetros, a umidade, índice de diastase e HMF. Os autores concluíram que méis suíços tiveram significativamente menores valores de umidade e HMF, e um índice de diastase maior que os dos méis estrangeiros. Os valores obtidos para méis suiços e estrangeiros foram, respectivamente, 15,7 e 17,9\% (umidade), 0,23 e $1,57 \mathrm{mg} / \mathrm{kg}$ (HMF) e, 21,4 e 16,9 (indice de diastase).

Faraji-Haremi \& Hosseini (1987) para amostras de méis iranianos encontraram valores médios e intervalo de variação de alguns parâmetros, tais como, umidade $(14,3 ; 13,0-16,0 \%), \mathrm{pH}(3,91 ; 3,5-4,3)$, acidez $(31,23 ; 24,5-43,5 \mathrm{meq} / \mathrm{kg})$ e sacarose $(1,71 ; 0,10-3,1 \%)$.

Imperatriz-Fonseca et al. (1987) estudando méis das regiões norte, nordeste e sul do Brasil, encontraram um conteúdo médio de proteína igual a $1,58 \%$ para amostras de méis de Citrus e 1,92-2,76\% para amostras de méis de Eucalyptus. Observaram que houve grande variação nas características químicas e fisicas das amostras de méis de Eucalyptus provenientes de diferentes espécies.

Lower (1987a) em suas considerações sobre produção, extração, purificação, armazenamento, condicionamento, desidratação, toxicidade com relação ao mel, também referiu-se a alguns valores de componentes de sua constituição, tais como: indice de diastase $(14,0), \mathrm{HMF}(1,5 \%)$ e sacarose $(6,5 \%)$.

Lower (1987b) relatou valores de diversos parâmetros de amostras de méis produzidas em diferentes países como, Brasil (umidade $=17,6 \% ; \mathrm{pH}=4,07$ ), Inglaterra (umidade $=17 \%$; açúcares redutores $=73 \%$; sacarose $=1 \%$, proteína $=2,0 \%$ ), Guiana Inglesa ( $\mathrm{pH}=4,23$; açúcares redutores $=75,8 \%$; sacarose $=8,67 \%)$, França (umidade $=20,64 \%$; açúcares redutores $=70,3 \%$; sacarose $=6,39 \%)$, Alemanha $(\mathrm{pH}=3,8$ 4,3 ), Índia (umidade $=14,17-26,67 \%$; açúcares redutores $=63,89-76,33 \%$; sacarose $=0,5 \%$ ), Itália (proteína $=0,13 \%$ ), Japão $\quad$ (umidade $=17,23 \%$; açúcares 
redutores $=68,3-75,1 \%$; sacarose $=0,2-3,5 \%$ ), Paquistão (umidade $=14,3-28,6 \%$; açúcares redutores $=71,1-76,9 \%$; sacarose $=1,9-2,8 \%$ ), Polonia (umidade $=21 \%$; sacarose $=5 \%$ ), Romania (umidade $=16,46 \%$; açúcares redutores $=75,64 \%$; sacarose $=3,10 \%$ ), África do Sul (umidade $=16 \% ; \mathrm{pH}=3,36-4,62$; açúcares redutores $=67,0 \%$; sacarose $=0,5 \%$ ), Suécia (umidade $=18,5 \%$ ), Ucrania (proteína $=0,36-1,2 \%$ ), Uruguai (umidade $=17,29 \%$; açúcares redutores $=67,3 \%$; sacarose $=4,95 \%$ ).

Mesallan \& El-Shaarawy (1987), baseando-se nas especificações estabelecidas pela "SASO-Saudi Arabia Standard Organization", avaliaram a qualidade não só dos méis produzidos no país, como também, dos importados para suprir a demanda do mercado saudita. As 5 amostras nacionais foram adquiridas diretamente do apicultor e as 8 amostras importadas, em supermercados e mercearias, provenientes da Ásia, Austrália, Europa e Estados Unidos. Foram determinados: umidade através do índice de refração (refratômetro Abbe, $20^{\circ} \mathrm{C}$ ); glicose, frutose e sacarose, pelo método HPLC (cromatógrafo); HMF, fotometricamente; $\mathrm{pH}$, em pH-metro; a acidez, por titulometria; o índice de diastase, através da hidrólise do amido; e proteína. Os resultados, valor médio e intervalo de variação, obtidos para cada parâmetro, respectivamente, para méis nacionais e importados foram: umidade $(14,6 \%, 13,8-15,6 \% ; 17,3 \%, 15,4-18,8 \%)$; acidez (19 meq $/ \mathrm{kg}, 13,0-24,0 \mathrm{meq} / \mathrm{kg} ; 25,0,19,0-30,0 \mathrm{meq} / \mathrm{kg}) ;$ índice de diastase $(17,7$, 13-30; 11,0, 5,5-20); HMF (13,0, 9,0-22,0 mg/kg; 119, 20,0-16,0 mg/kg); pH (3,8, 3,6$4,2 ; 3,8,3,6-4,3)$; proteína ( $0,25 \%, 0,21-0,28 \% ; 0,23 \%, 0,22-0,27 \%)$; açúcares redutores $(68,0 \%, 58,0-75,8 \% ; 66,0 \%, 48-73,5 \%)$ e sacarose $(6,7 \% ; 2,8-11,7 \% ; 5,5 \%$, 2,3-13,1\%). Com base nesses resultados, os autores concluíram que méis importados apresentaram valores menores que os nacionais para índice de diastase e açúcares redutores, e valores maiores para umidade e HMF; quanto ao $\mathrm{pH}$ e proteína não detectaram diferença estatisticamente significativa entre méis nacionais e importados. Os autores atribuíram os valores excessivamente altos de $\mathrm{HMF}$, referentes aos méis importados $(120,149,160,164 \mathrm{mg} / \mathrm{kg})$ a o armazenamento por longo período, a altas temperaturas, e, até, a uma possível adulteração; e a inativação da enzima diastase ao aquecimento severo.

Olek et al. (1987) pesquisando a composição química de méis do Nepal, um produzido por Apis cerana, a uma altitude de 1200-1500 m, e outro produzido por Apis laboriosa, a uma altitude de $1800 \mathrm{~m}$ encontraram, respectivamente, os seguintes valores médios: $\mathrm{pH}(5,57$ e 4,49); acidez (16,07 e 41,48 meq/kg); açúcares redutores 
$(74,26 \%$ e $64,70 \%)$, frutose $(40,25 \%$ e $36,05 \%)$, glicose $(34,01 \%$ e $28,65 \%)$, sacarose $(2,51 \%$ e $3,34 \%)$.

Tabio et al. (1987), trabalhando com caracterização de 31 amostras de méis cubanos de Citrus, encontraram uma umidade média de 17,6\%; açúcares redutores de $68,0 \%$; sacarose de 2,2\%; HMF de 4,16 mg/kg; índice de diastase de 37 unidades na escala Gothe e, acidez de $21,3 \mathrm{meq} / \mathrm{kg}$, verificando que todas as amostras de méis estavam em conformidade com os padrões cubanos.

Balenovic et al. (1988) concluíram que das 44 amostras de méis analisadas (22 obtidas diretamente dos apiários e 22 industriais) 54,4\% encontrava-se dentro dos requisitos padrões (índice de diastase $>8, \mathrm{HMF}<40 \mathrm{mg} / \mathrm{kg}$ ). Os autores observaram, em ambos os tipos de méis, uma significativa correlação entre HMF e índice de diastase.

Cornejo (1988) relatou breve histórico, definição, elaboração, métodos de análise das características químicas, fisicas e organolépticas do mel. Com relação às características fisico-químicas mencionou que: a) umidade, conteúdo de água no mel, é determinada em refratômetro com controle de temperatura. Em geral, os valores de umidade dos méis variam de 16 a 19\%, com valor médio de $17,6 \%$. Segundo o autor, o ideal é não ultrapassar $18 \%$, pois, com $19 \%$ certamente ocorre fermentação e o mel se deteriora; b) o valor de $\mathrm{pH}$ da solução de mel $50 \%$ é obtido através de leitura direta em pH-metro; c) acidez, que também dá indicação das condições de armazenamento e fermentação do mel pode ser determinada neutralizando a solução de mel com $\mathrm{NaOH}$ $0,1 \mathrm{~N}$ usando como indicador fenolftaleína alcóolica. Um mel de boa qualidade, segundo o autor, deveria ter um conteúdo médio normal de $10 \mathrm{meq} / \mathrm{kg}$; d) índice de diastase, também indica, a qualidade do mel, valores baixos estão relacionados com aquecimento e tempo de armazenamento; e) HMF, considerado um dos parâmetros mais importantes da análise de qualidade do mel, principalmente no que se refere a superaquecimento e envelhecimento. Sua determinação é realizada em espectrofotômetro, utilizando-se solução de p-toluídina e ácido barbitúrico $0,5 \%$. Em méis normais e novos o valor médio de HMF está por volta de $10 \mathrm{mg} / \mathrm{kg}$; f) açúcares redutores, principalmente glicose e frutose, constituem cerca de $72-73 \%$ do mel. Esse valor indica a riqueza de hidratos de carbono que são responsáveis pela consistência pegajosa e viscosa, conferindo ao mel uma alta densidade, oscilante entre 1,3 e 1,4. Esse conteúdo de açúcares redutores, também é o responsável pelo grande poder edulcorante do mel, cerca de $25 \%$ mais que o açúcar de mesa. 
Papoff et al. (1988) analisando 12 amostras de méis da Somália observaram que quatro delas eram genuínas. Obtiveram para as oito amostras de méis uma umidade média de $20,7 \%$ ( 17,0 a $23,8 \%$ ), sacarose $(1,7 \%)$, indice de diastase $(6,7)$ e HMF $(30,9 \mathrm{mg} / \mathrm{kg})$.

Serra-i-Bonvehi \& Canas-Lloria (1988) analisando amostras de méis de Eucalyptus produzidas comercialmente em 3 regiões da Espanha, verificaram uma umidade média de $16,8 \%$ e baixos conteúdos de sacarose, que variaram de 0,035 a $1,59 \%$.

Vit-Oliver (1988) num estudo sobre propriedades fisico-químicas, e organolépticas de 500 amostras de méis da Venezuela, colhidas entre 1985-1987 verificou que, ao comparar com os padrões venezuelanos, $39,8 \%$ das amostras não se enquadrava nos valores estabelecidos para umidade; $11,2 \%$ para açúcares redutores; $17,4 \%$ para sacarose; $25,5 \%$ para acidez; $43,2 \%$ para $\mathrm{HMF}$ e $34 \%$ para diastase.

Bricage (1989), em seu estudo com amostras de méis comercializadas em Paris, verificou que $81,8 \%$ delas se enquadrava nos limites permitidos (máximo $40 \mathrm{mg} / \mathrm{kg}$ para HMF).

Moraes et al. (1989) relatara m que a umidade relativa em algumas regiões do Brasil pode ser superior a $90 \%$ e o conteúdo de água no mel, em células operculadas, superior a $23 \%$. Esses autores reduziram, com sucesso, tal valor de umidade em 3-4\% em sala mantida a $40 \%$ UR.

White \& Winters (1989) utilizando a diferença de taxa de isótopo de carbono estável entre um mel e sua fração protéica, obtiveram uma avaliação objetiva de uma possivel adulteração de mel com pequenas (7-20\%) ou maiores quantidades de açúcar de cana ou milho. Cinqüenta amostras de méis, comprovadamente puras, foram utilizadas como padrões de pureza para as 38 amostras em teste a fim de verificar a autenticidade do produto.

Frias-Tejera et al. (1990) na análise de 38 amostras de méis obtiveram valores de $\mathrm{pH}$ variando de 3,6 a 6,1.

Frias-Tejera \& Torre (1990) estudaram o índice de diastase e HMF, que são considerados indicadores do grau de conservação do mel, em 38 amostras colhidas na província de Santa Cruz de Tenerife. Observaram uma grande variação de valores de HMF com um coeficiente de variação de $89,9 \%$, devido a três amostras que apresentaram elevados valores $(49,4 ; 56,4$ e $65,0 \mathrm{mg} / \mathrm{kg})$. Semelhantemente, o índice de diastase também apresentou essa variação de valores $(14,1 ; 4,67-32,1)$, com um coeficiente de 
variação igual a 40,3\%, mas que concordou com a de outros autores. Também observaram que amostras de méis com baixos valores de índice de diastase apresentavam elevadas quantidades de $\mathrm{HMF}$, e vice-versa. Finalmente os autores concluiram que ambos os parâmetros refletiram um bom estado de conservação dos méis, salientando que $92,1 \%$ das amostras estava enquadrada nas normas estabelecidas pela legislação espanhola para $\mathrm{HMF}$ ( $>40 \mathrm{mg} / \mathrm{kg}$ ) e índice de diastase (minimo 8, ou $3 \mathrm{se} \mathrm{HMF}<15 \mathrm{mg} / \mathrm{kg}$ ).

Gómez et al. (1990) utilizaram 18 amostras de méis, das quais, 3 foram colhidas diretamente dos apiários sem serem submetidas a processos tecnológicos de comercialização; as 15 restantes adquiridas no comércio, sendo marcas comerciais mais divulgadas e consumidas na Argentina. Uma das amostras comerciais era "mel" de canade-açúcar. Os parâmetros estudados, com os respectivos valores médios, foram: umidade $(15,75 \%), \mathrm{pH}(4,07)$, açúcares redutores $(66,27 \%)$ e sacarose $(1,52 \%)$. O "mel" de canade-açúcar apresentou baixos valores de glicose, o mais baixo de frutose $(19,64)$ e os maiores conteúdos de sacarose.

Pérez et al. (1990) consideraram parâmetros físico-químicos em méis monoflorais da província de Zaragosa, Espanha, visando continuar um estudo já iniciado, sobre tipificação de seus méis. Os autores determinaram a umidade, $\mathrm{pH}$ e acidez em 27 amostras de méis obtidas diretamente dos apicultores, sendo de quatro diferentes origens botânicas. Os resultados médios desses parâmetros foram para umidade $(16,74 \%), \mathrm{pH}$ $(3,72)$ e acidez $(19,45 \mathrm{meq} / \mathrm{kg})$. As amostras de méis de flores de árvores frutíferas (Prunus amygdalus e Prumus sp.) apresentaram os maiores valores médios de $\mathrm{pH}(4,16 \mathrm{e}$ $4,06)$ e acidez $(26,3$ e $25,50 \mathrm{meq} / \mathrm{kg})$.

Persano-Oddo et al. (1990) estudaram a presença da enzima diastase em 281 amostras de méis monoflorais italianos de diferentes origens botânicas, tais como, Arbustus (22), Erica (9), Robinia (76), Tarascacum (9), Citrus (18), Rhododendron (9), Helianthus (15), Hedysarum (29) "honeydew" (30), Castanea (92), Eucalyptus (23) e Thymus (11). Nesse estudo os autores apresentaram a variação no valor da diastase nas amostras de méis das diferentes origens botânicas. Os valores de índice de diastase encontrados para os citadas amostras foram respectivamente, iguais a 5,2; 7,8; 8,4; 9,2; 9,$8 ; 13,7 ; 16,3 ; 19,8 ; 22,9 ; 24,1 ; 25,5$ e 33,1 ; evidenciando a extrema variação deste parâmetro entre os grupos de méis monoflorais, e num grau naturalmente menor dentro deles. Os autores concluíram que essa variabilidade provavelmente se deve a uma série de fatores extrínsecos e intrínsecos incontroláveis. 
Através de eletroforese Rodriguez-Otero et al. (1990) caracterizaram amostras de méis da Galícia (Espanha) através de duas frações protẻicas das doze obtidas a partir das 82 amostras. Das amostras de méis estudadas, $86,5 \%$ pode ser classificada como mel da Galícia ou como mel processado.

Del Lungo et al. (1991) considerando que a Itália importou da Argentina $63 \%$ do total de mel consumido no primeiro semestre de 1988 , analisaram vários parâmetros relacionados à qualidade do mel, entre eles, umidade $(18,1 \%)$, acidez $(17,4)$, HMF $(0,8 \mathrm{mg} / \mathrm{kg})$, açúcares redutores $(70,5 \%)$ e sacarose $(0,8 \%)$. Então, foram comparados com as especificações estabelecidas pela lei italiana e argentina, respectivamente, umidade (máximo $21 \%$ e $18 \%$ ), acidez (máximo 0,25\% e $40 \mathrm{meq} / \mathrm{kg}$ ), $\mathrm{HMF}$ (máximo 40 e $40 \mathrm{mg} / \mathrm{kg}$ ), sacarose (máximo $5 \%$ e $8 \%$ ).

Da análise de 36 amostras de méis, Frias-Tejera \& Torre (1991) obtiveram um conteúdo médio de açúcares redutores de $81,9 \%$ (maior que o mínimo exigido de $65 \%$ ) e uma concentração média de sacarose de $5,1 \%$ (com quatro amostras excedendo o valor máximo permitido de $10 \%$ ). Uma das amostras apresentou um conteúdo de sacarose de 22,6\%, valor bastante alto comparado com o limite oficial.

Sancho et al. (1991) analisaram amostras de méis colhidas no outono de 1987 em três províncias da região de Basque, no norte da Espanha, sendo 50 provenientes de "Vizcaya", 19 de "Guipúzcoa" e 46 de "Alava". Entre os 18 parâmetros determinados, constavam umidade, $\mathrm{pH}$, acidez, número de formol e sacarose. $\mathrm{O}$ método direto, o "maxminf" e o "Wilks's lambda" determinaram corretamente 83,5\%, 82,6\% e $79,1 \%$, respectivamente, das 115 amostras de méis para as províncias de origem. $\mathrm{O}$ método direto exigiu os 18 parâmetros analisados, e o método "maxminf" somente 11 parâmetros, elegendo-o como o mais indicado.

White (1991) propôs um novo método para determinação de HMF pela análise "photometric flow injection" baseada na reação de Winkler.

Fernández-Salguero \& Gómez (1992) determinaram a umidade e pH de mel, que estava incluído no estudo de 38 tipos de alimentos espanhóis comerciais de baixa umidade. Os autores salientaram que o mel, com umidade $=15,75 \%$ e $\mathrm{pH}=4,08$, foi o produto que apresentou o menor valor de $\mathrm{pH}$ dentro da faixa de 4,08-6,72; quanto à umidade, esse valor foi mediano dentro da faixa 1,52-29,03.

Frias \& Hardisson (1992), num trabalho de revisão, apresentaram alguns parâmetros relacionados à qualidade do mel, com os respectivos métodos para sua 
determinação. Também são indicados os valores máximos permitidos pela legislação espanhola.

Escobar-Martínez et al. (1992) com objetivo de estabelecer normas de qualidade, um padrão para o mel, produzido por Apis mellifera L., no território paraguaio, e, um mapa apícola conforme as regiões meliferas, realizaram um estudo sobre a composição fisico-química, biológica e organoléptica de diferentes amostras de méis representativas do país. O Paraguai foi dividido em cinco zonas meliferas (I, região ocidental (Chaco); II, região ocidental (Norte); III, região oriental (Centro); IV, região oriental (Alto Paraná), e V, região oriental (Sul)), e entre os parâmetros determinados para cada uma delas com os respectivos resultados obtidos, em valores médios, estão: umidade $(19,49 \%), \mathrm{pH}$ a $25^{\circ} \mathrm{C}(4,37)$, acidez $(32,91 \mathrm{meq} / \mathrm{kg})$, açúcares redutores $(72,43 \%)$, sacarose aparente $(3,52 \%)$, proteina bruta $(1,63 \%), \operatorname{HMF}(22,73 \mathrm{mg} / \mathrm{kg})$ e índice de diastase $(41,61)$. Com base nesses resultados, o Departamento de Apicultura estabeleceu as seguintes normas de qualidade para o mel de abelhas de origem paraguaia: umidade (máximo 21\%), acidez (máximo $45 \mathrm{meq} / \mathrm{kg}$ ), açúcares redutores (mínimo 68\%), sacarose aparente (máximo 6\%), proteína bruta (mínimo 0,3\%), HMF (máximo 40 $\mathrm{mg} / \mathrm{kg}$ ) e índice de diastase (escala Gothe, mínimo 8).

Sancho et al. (1992) relacionaram o índice de diastase e HMF com o tempo de armazenamento do mel após sua extração; também sugeriram a possível criação de uma nova norma de controle de qualidade. Para tanto, amostras de méis colhidas em setembro/1987, diretamente de apicultores da região de Basque (Espanha), foram analisadas em janeiro dos anos 1988, 1989 e 1990, sendo que até estas datas foram armazenadas no laboratório à temperatura média de $20^{\circ} \mathrm{C}\left(15-25^{\circ} \mathrm{C}\right)$. $\mathrm{O}$ índice de diastase foi determinado aos 4, 16 e 28 meses após a extração da amostra; os valores médios obtidos foram de 4,7;13,1 e 33,2, respectivamente. Já o índice de diastase, determinado por método estabelecido pelos citados autores, apresentaram os valores médios para as mesmas épocas, respectivamente, iguais a 25,6;18,1 e 14,5. Os autores sugeriram como novos valores para as normas de qualidade para índice de diastase, mínimo de 8 (escala GOTHE) ou mínimo 3 (se $\mathrm{HMF}<10 \mathrm{mg} / \mathrm{kg}$ ) e para $\mathrm{HMF},<30 \mathrm{mg} / \mathrm{kg}$ sem esquecer a legislação vigente (Codex Alimentarius Commission, 1969).

White (1991) questionou o uso de índice de diastase como indicador de qualidade do mel devido a grande variação na quantidade de diastase em méis recémcolhidos, não aquecidos. Mencionou, o autor, que méis produzidos em regiões quentes e 
secas do mundo apresentam menores quantidades de enzima do que regiões quentes e úmidas.

Kim et al. (1993) também definiram intervalos de variação de valores de vários parâmetros como, umidade $(19,9$ a 20,3\%), acidez $(7,6$ a $10,86 \mathrm{meq} / \mathrm{kg})$ e sacarose $(1,7$ a $2,75 \%)$.

Martinez-Gomez et al. (1993) observando a tendência do povo espanhol em reduzir o consumo de açúcar refinado e habituar-se com o mel, determinaram 35 parâmetros em 25 amostras de méis de eucalipto (Eucalyptus sp.). Entre eles estavam incluídos: açúcares redutores, sacarose, umidade, $\mathrm{pH}$, acidez, $\mathrm{HMF}$ e índice de diastase. Encontraram os seguintes resultados médios: açúcares redutores $(68,6 \%)$, sacarose (2,02\%), umidade (16,19\%), pH (3,9), acidez (28,3 meq/ $\mathrm{kg})$, HMF $(3,6 \mathrm{mg} / \mathrm{kg})$ e indice de diastase, escala Gothe, $(20,12)$. Os autores consideraram as amostras de méis analisadas de boa qualidade.

Thrasyvoulou et al. (1994) num trabalho comparativo enfocando a descristalização de mel através de aquecimento (banho-maria a $60^{\circ} \mathrm{C}$ por 30 minutos) e de ultra-som ("MSE Soniprep 150 Ultrasonic Disintegrator", freqüência de $23 \mathrm{KHz}$ ) determinaram a umidade, índice de diastase e HMF além dos possiveis efeitos decorrentes destes tratamentos, sobre tais parâmetros. Os valores médios $\pm \mathrm{s}(\overline{\mathrm{m}})$ de $\mathrm{HMF}, 11,4 \pm 1,4$ ppm e $14,0 \pm 1,4 \mathrm{ppm}$, respectivamente para tratamento ultra-som e aquecimento, foram estatisticamente diferentes entre si e do tratamento testemunha. Para as condições experimentais do referido estudo, o tratamento por ultra-som é mais indicado que por aquecimento pois proporcionou menor aumento de HMF. Por outro lado, para índice de diastase, embora ambos os tratamentos sejam estatisticamente diferentes da testemunha, não diferiram entre si, e ambos provocaram redução do valor do índice de diastase. Nenhum dos tratamentos afetou significativamente a umidade ou $\mathrm{pH}$ dos méis analisados.

Num estudo comparativo de amostras de méis de 17 diferentes marcas, além das considerações à definição, produção, origem floral, cristalização, fermentação, produtos derivados e a outras informações sobre mel, a composição química do mesmo foi destacada no artigo ESTUDIO comparativo... (1994). A umidade determinada foi na faixa de 15,3 a 19,3\%, respectivamente para as marcas "El Quexigal" e "Alto Turia". Todas as amostras de méis apresentaram valores superiores a $75 \%$ em açúcares redutores, e nenhuma amostra atingiu o valor de $5 \%$ para sacarose, máximo permitido. Quanto à acidez, somente a amostra de mel da marca "Anta" não foi considerada boa, embora classificada como aceitável. Para HMF, os valores considerados bons, pelos 
autores, variam de 10 a $15 \mathrm{mg} / \mathrm{kg}$, entretanto, eles encontraram valores oscilando entre $3,8 \mathrm{mg} / \mathrm{kg}$ (marca "Anta") e 48,0 mg/kg (marca "El Quexigal").

White (1994) sugeriu que o índice de diastase fosse excluído da análise de qualidade de mel, por ser um teste redundante, enganoso e irracional. Para chegar a esta sugestão, o autor relatou o histórico não só do índice de diastase, mas também do HMF, mostrando, inclusive, como foram calculados os limites permitidos pela "Codex Alimentarius Commission". 


\section{MATERIAL E MÉTODOS}

A análise das amostras de méis, produzidas por $A$. mellifera, foi realizada no Laboratório de Apicultura do Departamento de Entomologia da Escola Superior de Agricultura "Luiz de Queiroz", USP/Campus-Piracicaba.

Tais amostras de méis foram obtidas através de contatos diretos com Universidades, Instituições de Pesquisa, Casas de Agricultura, profissionais do setor agropecuário e apicultores do Estado de São Paulo.

Dentre os parâmetros relacionados à análise de mel foram determinados: umidade, proteina, $\mathrm{pH}$, acidez, índice de formol, índice de diastase, hidroximetilfurfural (HMF), açúcares redutores (AR) e sacarose, visando uma caracterização das amostras de méis representativas do Estado de São Paulo.

Os resultados obtidos para todos os parâmetros estudados, de acordo com o respectivo método, foram comparados, após a análise estatística, com as especificações estabelecidas pela legislação brasileira, conforme publicação no Diário Oficial, em agosto/1985 (Brasil, 1985), para normas higiênico sanitárias e tecnológicas para mel, cera de abelhas e derivados (Tabela 1). 
Tabela 1. Especificações estabelecidas pela legislação brasileira para parâmetros determinados na análise de mel.

\begin{tabular}{ll}
\hline Parâmetro & Especificações \\
\hline Umidade & máximo $20 \%$ \\
Proteína & 0,6 a $3,0 \mathrm{ml}$ \\
$\mathrm{pH}$ & 3,3 a 4,6 \\
Acidez & máximo $40 \mathrm{meq} / \mathrm{kg}$ \\
Índice de formol & 4,5 a $15,0 \mathrm{ml} / \mathrm{kg}$ \\
Índice de diastase & mínimo 8, ou $3 \mathrm{se} \mathrm{HMF}<15$ \\
Hidroximetilfurfural (HMF) & máximo $40 \mathrm{mg} / \mathrm{kg}$ \\
Açúcares redutores & mínimo $72 \%$ \\
Sacarose & máximo $10 \%$ \\
\hline
\end{tabular}

Os citados valores referem-se à caracterização de amostras de méis de mesa, assim, amostras de méis que não se enquadrarem nestas especificações são automaticamente classificadas para fins industriais.

Foram coletadas 160 amostras de méis provenientes de 97 municípios paulistas, sendo 94 amostras de méis de flores silvestres (S), 27 de flores de eucalipto (E), 34 de flores de laranjeira (L) e 5 amostras de "méis" de exsudato de cana-de-açúcar (C) (Quadro I e Figura 1).

Com relação ao reduzido número de amostras de "méis" de exsudato de cana-de-açúcar considerado na presente pesquisa (5, correspondente a 3,1\% das amostras estudadas), fato semelhante foi constatado no trabalho de Gómez et al. (1990), que dentre as 18 amostras consideradas somente uma era de exsudato de cana-de-açúcar (1, correspondente a $5,6 \%$ das amostras por eles estudadas). 
Quadro I. Número de amostras de méis de flores silvestres (S), de eucalipto (E), de laranjeira (L) e de "méis" de exsudato de cana-de-açúcar (C) coletadas nos diferentes municipios do Estado de São Paulo.

\begin{tabular}{|c|c|c|c|c|c|c|c|c|c|}
\hline \multirow{2}{*}{$\begin{array}{l}\text { Município } \\
\text { (SP) }\end{array}$} & \multicolumn{4}{|c|}{ Méis/"Méis" } & \multirow{2}{*}{$\begin{array}{c}\text { Município } \\
\text { (SP) }\end{array}$} & \multicolumn{4}{|c|}{ Méis/"Méis" } \\
\hline & $\mathrm{S}$ & C & $E$ & $\mathrm{~L}$ & & $\mathrm{~S}$ & C & E & $\mathrm{L}$ \\
\hline Altinópolis & 1 & - & 1 & 1 & Juquitiba & 1 & - & - & - \\
\hline Amparo & - & - & 1 & - & Lagoinha & 1 & - & - & - \\
\hline Andradina & 1 & - & - & 1 & Lençóis Paulista & 1 & - & 2 & - \\
\hline Anhembi & - & - & 1 & - & Limeira & - & - & - & 1 \\
\hline Araçatuba & 2 & - & 1 & 1 & Lins & 1 & - & - & 1 \\
\hline Araraquara & - & 1 & 1 & 2 & Luiz Antonio & - & - & 2 & - \\
\hline Arthur Nogueira & - & - & - & 1 & Matão & - & - & - & 1 \\
\hline Assis & 1 & - & - & - & Mirandópolis & 1 & - & - & - \\
\hline Auriflama & 2 & - & - & 1 & Mirassol & 1 & - & - & - \\
\hline Avaré & - & - & 2 & - & Mogi Mirim & - & - & - & 1 \\
\hline Bananal & 1 & - & - & - & Monte Alegre do Sul & 1 & - & - & - \\
\hline Barretos & 1 & - & 1 & 2 & Monteiro Lobato & 1 & - & 1 & - \\
\hline Bebedouro & - & - & 1 & 5 & Nova Odessa & - & 1 & - & - \\
\hline Boa Esperança do Sul & 1 & - & - & - & Oriente & 1 & - & - & - \\
\hline Bofete & 1 & - & - & - & Palestina & - & - & - & 1 \\
\hline Botucatu & - & - & 1 & - & Paraíbuna & 1 & - & - & - \\
\hline Brotas & 1 & - & 2 & - & Paranapanema & 1 & - & - & - \\
\hline Caçapava & 1 & - & 1 & - & \begin{tabular}{|l|} 
Piedade \\
\end{tabular} & - & - & - & 1 \\
\hline Capão Bonito & 1 & - & - & - & Piracaia & 1 & - & - & - \\
\hline Casa Branca & - & - & - & 1 & Piracicaba & 1 & 1 & - & - \\
\hline Capela do Alto & 1 & - & - & 1 & Piracuama & 1 & - & - & - \\
\hline Castilho & 1 & - & - & 1 & Pirassununga & 1 & - & - & - \\
\hline Colina & 1 & - & - & - & \begin{tabular}{|l|} 
Presidente Prudente \\
\end{tabular} & 1 & - & - & - \\
\hline Conchal & - & - & - & 2 & Redenção da Serra & 2 & - & - & - \\
\hline Corumbataí & 1 & - & - & - & Rio Claro & 1 & - & 1 & - \\
\hline Cunha & 1 & - & - & - & Sabino & 2 & - & - & - \\
\hline Descalvado & - & - & - & 1 & Santa Cruz do Rio Pardo & 1 & - & - & - \\
\hline Espirito Santo do Pinhal & 1 & - & - & - & Santa Fé do Sul & 1 & - & - & - \\
\hline Estrela D'Oeste & 2 & - & - & - & \begin{tabular}{|l|} 
Santo Antonio do Pinhal \\
\end{tabular} & 1 & - & - & - \\
\hline Gália & 1 & - & - & - & São Carlos & 1 & - & - & 1 \\
\hline Getulina & - & - & - & 1 & São João da Boa Vista & 1 & - & - & - \\
\hline Guarani D'Oeste & 1 & - & - & - & São José do Rio Preto & 2 & - & 1 & 1 \\
\hline Guareí & 2 & - & - & - & São Luís do Paraitinga & 2 & - & - & - \\
\hline Guarujá & 1 & - & - & - & São Pedro & 2 & - & 1 & - \\
\hline Igarapava & 1 & - & - & - & São Roque & 3 & - & - & - \\
\hline Ilha Solteira & 1 & - & - & - & Serra Negra & 5 & - & - & $=$ \\
\hline Ipeúna & - & - & 1 & - & Sete Barras & 1 & - & - & - \\
\hline Itaberá & 1 & - & - & - & Tabatinga & - & - & - & 1 \\
\hline Itanhaém & 1 & - & - & - & Taquaritinga & - & - & - & 1 \\
\hline Itapetininga & 1 & - & 1 & - & Taubaté & 1 & - & - & - \\
\hline Itapeva & 1 & - & - & - & Tietê & 1 & - & - & $=$ \\
\hline Itapira & 1 & - & 1 & - & Torinha & 2 & - & 1 & 1 \\
\hline Itapirapuã Paulista & 1 & - & - & - & Tremembé & 1 & - & - & - \\
\hline Ituverava & 1 & - & - & - & Ubatuba & 1 & - & - & - \\
\hline Jaboticabal & - & 2 & 1 & - & Vargem Grande do Sul & 1 & - & 1 & 1 \\
\hline Jarinu & 1 & - & - & - & \begin{tabular}{|l} 
Valentin Gentil \\
\end{tabular} & 1 & - & - & - \\
\hline Joanópolis & 1 & - & - & - & \begin{tabular}{|l} 
Vista Alegre do Alto \\
\end{tabular} & 1 & - & - & 1 \\
\hline Jundiai & 3 & - & - & - & Votorantin & 1 & - & - & - \\
\hline Junqueirópolis & 2 & - & - & - & & $=$ & 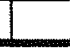 & & \\
\hline
\end{tabular}



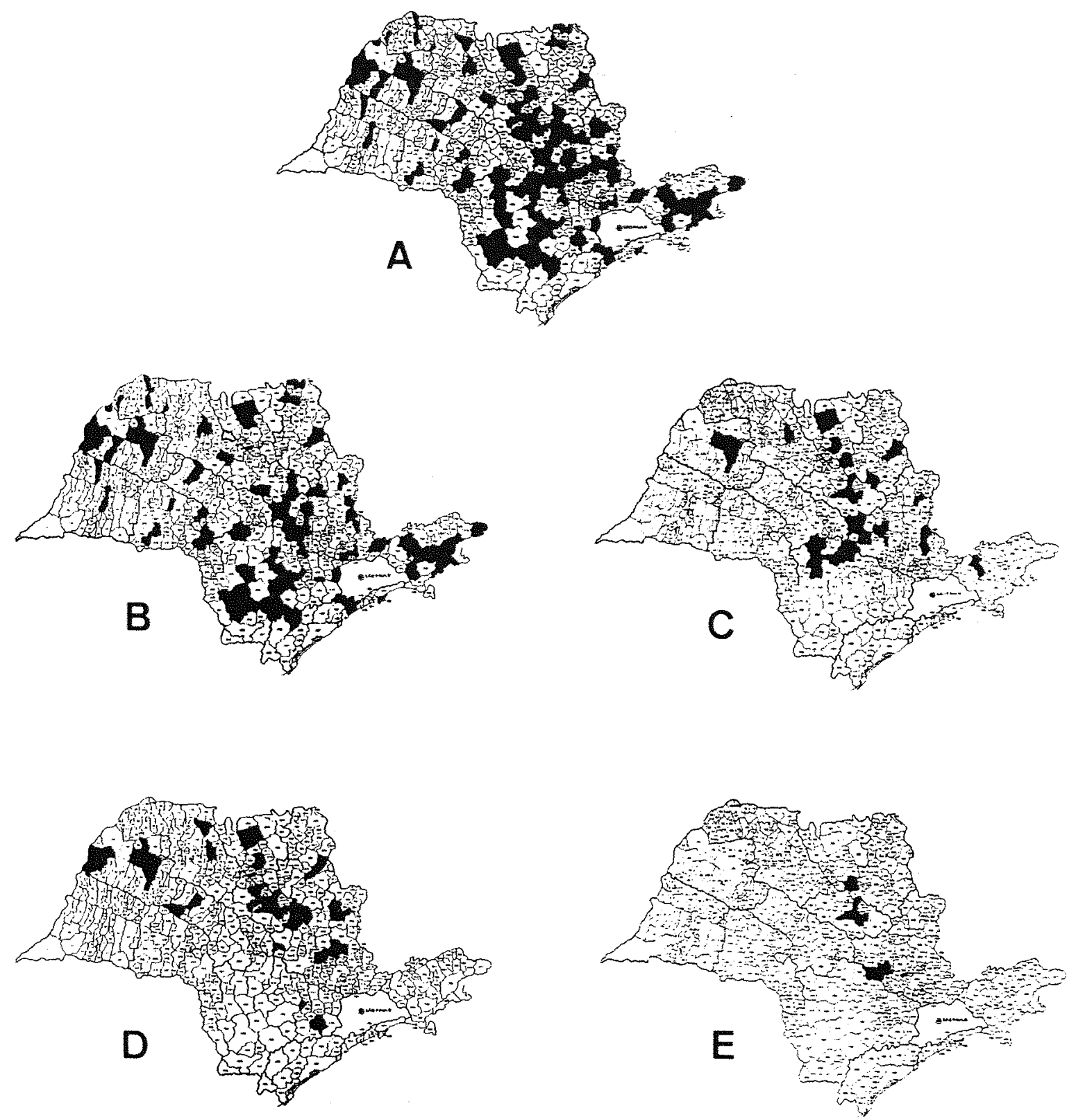

municípios paulistas de onde provieram as amostras

Figura 1. Municípios paulistas e respectivas amostras estudadas (A), amostras de méis de flores silvestres (B), de eucalipto (C), de laranjeira (D) e de "méis" de exsudato de cana-deaçúcar (E). 


\subsection{Umidade}

A umidade das diferentes amostras de méis foi determinada através de um refratômetro manual marca ATAGO (luz natural, temperatura ambiente) específico para mel. O referido aparelho dispõe de uma escala, que expressa diretamente o valor da umidade (\%), sendo feita uma correção em função da temperatura num termômetro a ele acoplado externamente. Este aparelho foi adaptado a partir do refratômetro Abbe e possui um alto contraste no campo de visão (ATAGO Co. Ltda., 1988).

O método baseia-se no fenômeno da refração (relação entre as velocidades da luz no vácuo e numa substância) que um raio de luz incidente sofre ao incidir na solução de mel, que contém sólidos solúveis.

$\mathrm{Na}$ determinação deste parâmetro, primeiramente, com o refratômetro em posição de leitura (prismas justapostos) e janela suplementar de luz aberta, foi acertado o foco da escala interna, girando-se um botão próximo à lente ocular. Uma vez acertado o foco desta escala e fechada a janela suplementar de luz, os prismas foram afastados e, com um bastão de vidro, uma gota (aproximadamente $0,5 \mathrm{~cm}$ de diâmetro) de mel, não cristalizado e homogeneizado, foi colocada sobre o prisma suplementar (inferior). Novamente com o aparelho em posição de leitura e visando-se em direção à luz natural (claridade da janela do laboratório) acertou-se o foco da linha limite entre os hemisférios, através de um botão próximo aos prismas, procedendo-se à leitura direta. Imediatamente após a leitura da umidade foi feita a correção indicada no termômetro lateralmente anexo ao aparelho que consistiu na adição ou subtração de valores que variavam de 0,0 a 0,5.

Cinco amostras de méis de flores silvestres foram recebidas já cristalizadas, o que impediu a imediata determinação das respectivas porcentagens de umidade. Tais amostras foram, então, descristalizadas em banho-maria a uma temperatura na faixa de $46-50^{\circ} \mathrm{C}$, para depois serem submetidas ao refratômetro.

O valor da umidade (\%) resultou da média de 6 leituras para cada amostra de mel. 


\subsection{Proteína}

A proteína do mel foi determinada seguindo-se o método do Laboratório do Centro de Apicultura Tropical-IZ (Pindamonhangaba/SP), que adota a reação de Lund para determinação do referido parâmetro.

O fundamento deste método está no fato do ácido tânico precipitar as substâncias albuminóides (proteínas) que são componentes normais do mel.

Num béquer, $2 \mathrm{~g}$ de mel foram pesados e dissolvidos em cerca de $15 \mathrm{ml}$ de água destilada, homogeneizando-se com bastão de vidro. Esta solução de mel foi transferida para uma proveta graduada, de $50 \mathrm{ml}$, lavando-se cuidadosamente o bastão e a parede interna do béquer com pequenas quantidades de água destilada.

Então, foram acrescentados $5 \mathrm{ml}$ de ácido tânico $0,5 \%$ e o volume completado com água destilada até $40 \mathrm{ml}$. Após completa homogeneização, $20 \mathrm{ml}$ foram transferidos para um tubo de ensaio, de $20 \mathrm{ml}$, com escala de graduação e possuidor de borda, onde o material permaneceu em repouso por 24 horas. Após esse período de tempo, observou-se ou não a presença de um precipitado no fundo do tubo, que quando presente foi avaliado em termos de $\mathrm{ml}$ através da escala tubo de ensaio. $\mathrm{O}$ resultado consistiu na leitura obtida multiplicada por 2 devido à citada redução do volume. para $\sqrt{(x+1)}$.

Os dados observados, para fins de análise estatística, foram transformados

\section{3. Índice de $\mathrm{pH}$, acidez e índice de formol}

$\mathrm{O}$ índice de $\mathrm{pH}$, a acidez e o índice de formol das diferentes amostras de méis foram determinados segundo o método adotado pelo Laboratório do Centro de Apicultura Tropical-IZ (Pindamonhangaba/SP).

Os 3 parâmetros foram determinados em seqüência, com duas repetições para cada amostra de mel.

Dissolveram-se $10 \mathrm{~g}$ de mel em $75 \mathrm{ml}$ de água destilada, homogeneizandose com bastão de vidro. Durante o decorrer dessas 3 determinações a solução de mel esteve sob constante agitação magnética. 


\subsubsection{Indice de $\mathrm{pH}$}

Consiste na determinação da concentração de íons hidrogênio presentes na solução de mèl.

Um pH-metro foi calibrado com soluções tampão $\mathrm{pH}=6,86 \mathrm{e} \mathrm{pH}=2,0$. Este aparelho e uma bureta, de $25 \mathrm{ml}$, foram acoplados ao béquer contendo a solução de mel, sob agitação constante.

$\mathrm{Na}$ referida solução foi introduzida a ampola contendo o eletrodo do aparelho, com o botão na posição "stand-by". Passados 3 minutos, para fins de estabilização, colocou-se o botão na posição $\mathrm{pH}$ anotando-se o valor exibido no visor digital.

$\mathrm{O}$ valor do $\mathrm{pH}$ para cada amostra de mel resultou da média de 2 leituras.

\subsubsection{Acidez}

O método é baseado na neutralização da solução ácida de mel pela solução de $\mathrm{NaOH} 0,1 \mathrm{~N}$, utilizando fenolftaleína como indicador.

Para sua determinação, obtido o valor do $\mathrm{pH}, 3$ gotas de fenolftaleína $1 \%$ (em álcool anidro) foram colocadas na solução de mel. Em seguida, titulou-se com solução de $\mathrm{NaOH} 0,1 \mathrm{~N}$ contida na bureta até que o ponto de viragem, com a coloração final persistindo por 10 segundos. $\mathrm{O}$ volume gasto da referida solução foi anotado.

$\mathrm{O}$ valor da acidez foi calculado multiplicando-se o volume gasto de $\mathrm{NaOH}$ $0,1 \mathrm{~N}$ por 10 (peso da amostra). $\mathrm{O}$ valor da acidez resultou da média de 2 determinações, sendo expresso em meq $/ \mathrm{kg}$ de mel.

para $\sqrt{(x+0,5)}$.

Os dados observados, para fins de análise estatística, foram transformados

\subsection{3. Índice de formol}

Fundamenta-se na combinação do formaldeído com os grupos amínicos dos aminoácidos, que nesta reação são neutralizados pela solução $\mathrm{NaOH} 0,1 \mathrm{~N}$ $\left(\right.$ Veríssimo $\left.^{2}\right)$.

-VERISSÍMO, M.T.S. (Instituto de Apicultura do Estado de Santa Catarina.). Correspondência pessoal, 1987. 
Após a determinação da acidez acrescentou-se mais um volume de $\mathrm{NaOH}$ $0,1 \mathrm{~N}$, contido na bureta, até que a solução atingisse a faixa de $\mathrm{pH}=8,3-8,5$.

Em seguida, foi colocado um volume de ácido acético glacial $0,1 \mathrm{~N}$, suficiente para baixar o valor do $\mathrm{pH}$ para 8,0. A partir dai, foram cronometrados 2 minutos para, então, acrescentar $4,3 \mathrm{ml}$ de formaldeído. Após um minuto foi realizada a titulação com $\mathrm{NaOH} 0,1 \mathrm{~N}$, novamente até $\mathrm{pH}=8,0$, anotando-se o volume gasto.

$\mathrm{O}$ indice de formol, também, foi obtido multiplicando-se esse volume gasto por 10( peso da amostra ), sendo expresso em $\mathrm{ml} / \mathrm{kg}$ de mel. para $\sqrt{(x+0,5)}$

Os dados observados, para fins de análise estatística, foram transformados

\section{4. Índice de diastase}

$\mathrm{O}$ índice de diastase foi determinado segundo o método adotado pelo Instituto de Tecnologia de Alimentos-ITAL (Campinas/SP) e baseia-se na reação do iodo com o amido hidrolisado pela diastase, conforme segue.

Num béquer, $10 \mathrm{~g}$ de mel foram diluídos em cerca de $20 \mathrm{ml}$ de água destilada, seguindo-se à homogeneização com um bastão de vidro. Essa solução de mel foi transferida para um balão volumétrico, de $100 \mathrm{ml}$, tomando-se o cuidado de lavar a parede interna do béquer com água destilada. Adicionaram-se 3 gotas do indicador fenolftaleína $1 \%$ procedendo-se, então, à neutralização com solução de $\mathrm{NaOH} 0,1 \mathrm{~N}$ até $\mathrm{o}$ ponto de viragem (coloração levemente rosada). Atingido o ponto de viragem, o volume do balão foi completado com água destilada até a marca de aferição, reservando-se esta solução de mel.

A seguir, preparou-se uma bateria de 10 tubos de ensaio com tampa $(13,0$ $\mathrm{x} 1,5 \mathrm{~cm}$ ) devidamente numerados (de 1 até 10 ) e acondicionados em uma grade-suporte. Em cada um dos tubos foram colocadas quantidades pré estabelecidas de água destilada; da solução de mel previamente preparada; e, de uma solução constituída por $100 \mathrm{ml}$ de solução de amido $1 \%, 10 \mathrm{ml}$ de solução $\mathrm{NaCl} 0,1 \mathrm{~N} \mathrm{e} 10 \mathrm{ml}$ de solução de ácido acético $0,02 \mathrm{~N}$ (Tabela 2). 
Tabela 2. Quantidades (ml) de água destilada, solução de mel e solução (amido $+\mathrm{NaCl}+$ ác. acético) a serem colocadas em cada um dos dez tubos de ensaio.

\begin{tabular}{cccc}
\hline Tubo & Solução de mel & Água destilada & Solução (amido+NaCl+ác.acético) \\
\hline 01 & 10,0 & 0,0 & 6,0 \\
02 & 7,7 & 2,3 & 6,0 \\
03 & 6,0 & 4,0 & 6,0 \\
04 & 4,6 & 5,4 & 6,0 \\
05 & 3,6 & 6,4 & 6,0 \\
06 & 2,8 & 7,2 & 6,0 \\
07 & 2,1 & 7,9 & 6,0 \\
08 & 1,7 & 8,3 & 6,0 \\
09 & 1,3 & 8,7 & 6,0 \\
10 & 1,0 & 9,0 & 6,0 \\
\hline
\end{tabular}

Após a adição das respectivas soluções, os tubos foram tampados, agitados e levados ao banho-maria a uma temperatura constante de $48^{\circ} \mathrm{C}\left(46-50^{\circ} \mathrm{C}\right)$ por uma hora. Após esse período, os tubos foram rapidamente resfriados em banho de gelo (recipiente com gelo+água) por aproximadamente 5 minutos. Retirados do banho de gelo, os tubos receberam 2 gotas de solução de iodo $0,1 \mathrm{~N}$, sendo novamente tampados e agitados até a visualização da coloração azul em alguns deles.

Para cada amostra de mel foi realizada uma determinação. O valor do índice de diastase da amostra de mel, em questão, correspondeu ao valor atribuído ao tubo anterior àquele a partir do qual se iniciou a sequeência de tubos com coloração azul. Os valores numéricos deste parâmetro, para cada tubo, são apresentados na Tabela 3.

Tabela 3. Índice de diastase (ID) correspondente a cada tubo

\begin{tabular}{cccc}
\hline Tubo & ID & Tubo & ID \\
\hline 1 & 5.0 & 6 & 17,9 \\
2 & 6.5 & 7 & 23,8 \\
3 & 8.3 & 8 & 29,4 \\
4 & 10.9 & 9 & 38,5 \\
5 & 13.9 & 10 & 50,0 \\
\hline
\end{tabular}


Esses valores de índice de diastase correspondem ao volume, em $\mathrm{ml}$, da solução de amido $1 \%$, que foi hidrolisado pela quantidade de enzima contida em $1 \mathrm{~g}$ de mel. para $\sqrt{(x+0,5)}$.

Os dados observados, para fins de análise estatística, foram transformados

\subsection{Hidroximetilfurfural}

O hidroximetilfurfural (HMF) foi determinado seguindo-se o método adotado no Laboratório do Centro de Apicultura Tropical-IZ (Pindamonhangaba/SP).

Baseado na reação de Winkler ${ }^{3}$, citado por Moraes (1988), onde, em meio ácido, o hidroximetilfurfural, o ácido barbitúrico e a p-toluídina formam um produto de condensação de coloração vermelha, que é posteriormente avaliada em espectrofotômetro/colorímetro.

Utilizou-se um colorímetro fotoelétrico marca DIGIMED modelo DME11, cubeta cilíndrica de vidro com diâmetro externo igual a $12 \mathrm{~mm}$ e passo óptico de 10 $\mathrm{mm}$. Este aparelho foi ajustado para um comprimento de onda igual a $520 \mathrm{~nm}$.

Após 15 minutos, para estabilização do colorimetro, a chave seletora foi posicionada em \%T (Transmitância); com o porta-cubeta vazio e fechado, foi ajustado $0 \%$ de transmitância no visor digital. Em seguida, uma cubeta contendo glicerina pura foi colocada em posição de leitura e ajustado $100 \%$ de transmitância no visor através dos botões de ajuste grosso e fino; então, quando a chave seletora era posicionada em Absorbância (A), o visor zerava. Desse modo o equipamento estava pronto para operar. Após cada leitura de absorbância da amostra e do branco, de cada mel, o colorímetro foi zerado com glicerina pura.

Num béquer, $5 \mathrm{~g}$ de mel foram dissolvidos em aproximadamente $15 \mathrm{ml}$ de água destilada, agitando-se com bastão de vidro. Esta solução foi transferida para balão volumétrico, de $25 \mathrm{ml}$, lavando-se cuidadosamente a parede interna do béquer com pequenas quantidades de água destilada; completou-se o volume à marca de aferição, após homogeneização.

\footnotetext{
${ }^{3}$ WINKLER, O. Beitrag zum Nadrweis und zur Bestimmung von Oxymethylfurfural in Honig un Kusnsthonig. Z. Lebeusmittel - Unter such. u. Forsch., v. 102, p. 161-4, 1955.
} 
Em dois tubos de ensaio, com borda, foram colocados $2 \mathrm{ml}$ da solução de mel e $5 \mathrm{ml}$ da solução de p-toluídina ( $100 \mathrm{ml}$ dessa solução são compostos por $10 \mathrm{~g}$ de $\mathrm{p}$ toluídina, $50 \mathrm{ml}$ de álcool isopropilico e $10 \mathrm{ml}$ de ácido acético glacial, completando-se o volume com álcool isopropílico).

Em seguida, em um dos tubos foi acrescentado $1 \mathrm{ml}$ de água destilada e no outro, $1 \mathrm{ml}$ da solução de ácido barbitúrico $0,5 \%$. Ambos os tubos foram agitados e homogeneizados manual e simultaneamente por aproximadamente 1,5 minuto. Após esse período duas cubetas do colorímetro foram lavadas com a respectiva solução contida nos tubos de ensaio e, depois, completadas até a marca preestabelecida. Imediatamente foram tomadas as leituras de absorbância (A) da solução contida em cada cubeta, daquela contendo água destilada (=branco), e da outra contendo ácido barbitúrico 0,5\% (=amostra). Para essas leituras, o aparelho sempre foi previamente zerado com glicerina pura. Mais duas leituras, como estas, foram realizadas para novas soluções submetidas ao colorímetro.

De posse dos valores das 3 leituras de absorbância (da amostra $=\mathrm{A}$ e do branco=B) o valor médio de HMF para cada amostra de mel, expresso em $\mathrm{mg} / \mathrm{kg}$ de mel, foi calculado através da seguinte fórmula:

$$
\mathrm{HMF}(\mathrm{mg} / \mathrm{kg})=[(\mathrm{A}-\mathrm{B}) \times 19,2 / \text { espessura da cubeta }] \times 10
$$

onde, espessura da cubeta $=1 \mathrm{~cm}$ para $\sqrt{(x+1)}$.

Os dados observados, para fins de análise estatística, foram transformados

\subsection{Açúcares redutores totais e açúcares redutores}

Para a determinação de açúcares redutores totais (ART\%) e açúcares redutores (AR\%), expressos em glicose, foram realizadas adaptações no método estabelecido pelo Departamento de Ciência e Tecnologia Agroindustrial, Setor Açúcar e Álcool, da ESALQ/USP, nas análises de mosto de cana-de-açúcar.

$\mathrm{O}$ método, para ambas as determinações, baseia-se na capacidade de açúcares redutores, como glicose e frutose, reduzirem o cobre presente na solução 
cuproalcalina (licor de Fehling) passando-o da forma $\mathrm{Cu}^{2+}$ para $\mathrm{Cu}^{+}$(redução de íons cúpricos em cuprosos) sendo que os açúcares são oxidados a ácidos orgânicos.

Para tanto utilizou-se um aparelho de oxiredutimetria por titulação Redutec, marca TECNAL, modelo TE 086. Basicamente, este aparelho elétrico consta de uma caldeira dotada de torneira e aquecimento produzido por uma resistência elétrica; uma câmara destinada ao licor de Fehling com saída de dejetos por uma torneira de drenagem. $\mathrm{O}$ aparelho é acoplado a um sistema de vácuo proporcionado pela trompa de vácuo que é fixada diretamente na torneira da pia; bureta de Mohr (50 ml) e garra Castaloy, que são fixados em uma haste.

Após cada titulação, a câmara do Redutec foi cuidadosamente lavada com água destilada, $\mathrm{HCl} 5 \%$ e novamente com água destilada, sob vácuo.

O licor de Fehling utilizado nessas determinações, foi preparado misturando-se volumes iguais, através de pipeta volumétrica, da solução A e da solução B de Fehling.

A solução A foi preparada pesando-se $69,28 \mathrm{~g}$ de sulfato de cobre $\left(\mathrm{CuSO}_{4} \cdot 5 \mathrm{H}_{2} \mathrm{O}\right)$, que foram transferidos para um béquer de $1000 \mathrm{ml}$. Foram adicionados $500 \mathrm{ml}$ de água destilada e a solução solubilizada através de agitação magnética. Após homogeneizada, a solução foi transferida para um balão volumétrico, de $1000 \mathrm{ml}$, lavando-se cuidadosamente a parede interna do béquer com pequenas quantidades de água destilada de uma piceta. Em seguida, o volume foi completado a $1000 \mathrm{ml}$ e a solução bem homogeneizada. Esta solução foi acondicionada em frasco de vidro de cor âmbar e deixada em repouso por 48 horas antes de ser utilizada.

Para o preparo da solução $\mathrm{B}$, foram pesados $346 \mathrm{~g}$ de tartarato duplo de sódio e potássio $\left(\mathrm{C}_{4} \mathrm{H}_{4} \mathrm{KNaO}_{6} \cdot 4 \mathrm{H}_{2} \mathrm{O}\right)$, aos quais foram acrescentados $300 \mathrm{ml}$ de água destilada. Essa solução foi solubilizada por agitação com bastão de vidro e aquecida em banho-maria sem que a mesma entrasse em ebulição e, então, reservada.

Em outro béquer, foram pesados $100 \mathrm{~g}$ de hidróxido de sódio $(\mathrm{NaOH}) \mathrm{e}$ dissolvidos em $200 \mathrm{ml}$ de água destilada sob banho de água fria, ou seja, o béquer foi mantido dentro de uma recipiente contendo água gelada e cubos de gelo.

Preparadas essas duas soluções, as mesmas foram transferidas para um balão volumétrico, de $1000 \mathrm{ml}$, lavando-se cada béquer com pequenas quantidades de água destilada e homogeneizando através de movimentos rotatórios. Quando necessário, a solução foi resfriada em banho de água corrente. Então, o volume foi completado a $1000 \mathrm{ml}$ e a solução novamente homogeneizada. Transferida para frasco de vidro de cor 
âmbar, a solução B de Fehling, também, permaneceu 48 horas em repouso antes de ser utilizada. O licor de Fehling foi padronizado sistematicamente com solução de açúcar invertido $0,2 \%$, de modo a se obter o valor do fator de correção do licor de Fehling (f), que é utilizado na fórmula para cálculo de AR\% e ART\%.

Para essa padronização do licor de Fehling, primeiramente preparou-se uma solução de açúcar invertido $2 \%$ pesando-se, em balança analítica, $19 \mathrm{~g}$ de sacarose p.a. $\left(\mathrm{C}_{12} \mathrm{H}_{22} \mathrm{O}_{11}\right)$ seca por uma noite em dessecador, que foram transferidos para balão volumétrico, de $1000 \mathrm{ml}$, juntamente com $200 \mathrm{ml}$ de água destilada. Após dissolver completamente a sacarose, através de movimentos rotatórios, adicionaram-se $10 \mathrm{ml}$ de ácido clorídrico p.a. ( $\mathrm{HCl}$, marca Merck, densidade=1,19). Em seguida à homogeneização através de movimentos rotatórios, o balão foi tampado e deixado em repouso por 72 horas à temperatura ambiente não inferior a $20^{\circ} \mathrm{C}$. Decorrido esse tempo o volume do balão foi completado à marca de aferição com água destilada e, esta solução foi armazenada em frasco de vidro de cor âmbar, bem vedado e conservado em geladeira.

Para o preparo da solução de açúcares invertidos $0,2 \%$, foram transferidos $20 \mathrm{ml}$ da solução de açúcares invertidos $2 \%$ para um balão volumétrico de $200 \mathrm{ml}$, adicionando-se, com proveta, $100 \mathrm{ml}$ de água destilada. Utilizando-se papel de Tornassol vermelho (marca Reagen), como indicador, procedeu-se à neutralização com uma solução de $\mathrm{NaOH} 20 \%$, cujo ponto de viragem se deu com a mudança da cor rosa para azul. Em seguida, o volume do balão foi completado à marca de aferição com água destilada, homogeneizando-se bem.

Para a padronização propriamente dita, completou-se a bureta de Mohr com solução de açúcares invertidos $0,2 \%$. Do licor de Fehling, previamente preparado, $10 \mathrm{ml}$ foram transferidos para a câmara do Redutec, aos quais foram adicionados $24 \mathrm{ml}$ da solução contida na bureta de Mohr. Com a tomeira da caldeira aberta e as demais fechadas, acionou-se ao máximo o aquecimento até saírem os primeiros vapores; então, a torneira foi fechada e quando a solução da câmara entrou em ebulição reduziu-se o aquecimento à metade, aguardando-se 2 minutos. Após esse tempo, foram adicionadas 3 gotas de solução de azul de metileno $1 \%$ procedendo-se à titulação gota-a-gota com a solução de açúcares invertidos $0,2 \%$, contida na bureta de Mohr, até a viragem da cor azul para vermelho tijolo. Atingido o ponto de viragem, anotou-se o volume gasto da solução de açúcares invertidos $0,2 \%$.

Foram feitas duas titulações e tirada a média dos volumes gastos, cujos valores diferiram, no máximo, 0,2 $\mathrm{ml}$ entre si. 
O fator de correção do licor de Fehling foi calculado através da seguinte fórmula:

$$
f=25,64 / v
$$

onde, $\mathrm{v}=$ volume da solução de açúcares invertidos $0,2 \%$ gasto na titulação do licor de Fehling.

Este fator sempre deverá estar entre 0,95 e 1,05; caso contrário deve-se corrigir a concentração da solução de cobre.

Para a determinação desses açúcares (AR e ART) foram realizadas para cada amostra de mel, uma titulação a quente (para se conhecer o volume a ser utilizado nas titulações a frio) e duas titulações a frio, de modo que os volumes de solução de mel gastos, em cada uma delas, diferissem no máximo $0,2 \mathrm{ml}$ entre si.

Quanto aos métodos de determinação desses açúcares a diferença está no fato de ART exigir solução de mel hidrolisada, ao passo que para AR utiliza-se simples diluição em água destilada.

Num béquer, $1,1 \mathrm{~g}$ de mel foi dissolvido, com o auxilio de um bastão de vidro, em cerca de $20 \mathrm{ml}$ de água destilada, até sua completa homogeneização. Esta solução de mel foi transferida para um balão volumétrico, de $100 \mathrm{ml}$, lavando-se o bastão e a parede interna do béquer com pequenas quantidades de água destilada. Após a homogeneização completou-se o volume à marca de aferição com água destilada, reservando-se esta solução.

\subsubsection{Açúcares redutores totais (ART\%)}

Procedendo-se à referida hidrólise, $50 \mathrm{ml}$ da solução de mel previamente preparada foram transferidos para uma balão volumétrico, de $200 \mathrm{ml}$; em seguida foram adicionados $10 \mathrm{ml}$ de $\mathrm{HCl} 6,34 \mathrm{~N}$ e homogeneizados com movimentos rotatórios. Levouse ao banho-maria com o termômetro dentro do balão volumétrico, estando o bulbo totalmente imerso na solução de mel, até que a mesma atingisse $65^{\circ} \mathrm{C}$. Durante o banhomaria a solução foi agitada com movimentos rotatórios e, ao ser retirado, o termômetro foi cuidadosamente lavado com pequena quantidade de água destilada para evitar perdas de açúcares. 
Imediatamente, a solução do balão foi deixada em repouso à temperatura ambiente e protegida de ventos durante 30 minutos. Após esse período de tempo, a solução foi neutralizada com $\mathrm{NaOH} 20 \%$ usando-se como indicador papel de Tornassol vermelho (marca Reagen).

Após neutralizada, a solução de mel foi resfriada em água corrente e o volume do balão completado a $200 \mathrm{ml}$ com água destilada.

Passando-se ao aparelho Redutec, primeiramente foi realizada uma titulação a quente para se conhecer o volume de solução hidrolisada de mel a ser acrescentado ao licor de Fehling nas duas titulações a frio subsequentes. A limpeza da câmara do Redutec foi cuidadosa e rigorosamente realizada utilizando-se solução $\mathrm{HCl}$ $5 \%$ e água destilada.

Para a titulação a quente, completou-se a bureta de Mohr, de $50 \mathrm{ml}$, com a solução hidrolisada, eliminando-se as possiveis bolhas em sua extremidade inferior. Através de uma pipeta volumétrica, $10 \mathrm{ml}$ do licor de Fehling foram transferidos para a câmara do Redutec, mantendo-se o aquecimento ao máximo. Quando os primeiros vapores foram liberados, a torneira foi fechada e, com o licor entrando em ebulição, o aquecimento foi reduzido à metade. A partir daí, foi cronometrado 1,5 minuto, após o que, 3 gotas de azul de metileno $1 \%$ foram adicionadas ao licor. Imediatamente iniciou-se a titulação gota-a-gota com a solução hidrolisada de mel até atingir o ponto de viragem, ou seja, a mudança da cor da solução, contida na câmara, de azul para vermelho tijolo. Atingido o ponto de viragem, anotou-se o volume gasto.

De posse do valor do volume gasto na titulação a quente, foram realizadas duas titulações a frio subsequentes, cujos volumes anotados puderam diferir no máximo em $0,2 \mathrm{ml}$.

Para a titulação a frio, novamente a bureta de Mohr foi completada com a solução hidrolisada de mel e, $10 \mathrm{ml}$ do licor de Fehling foram colocados, com pipeta volumétrica, na câmara do Redutec, mantendo a torneira da caldeira aberta e as demais fechadas.

Foi, então, acrescentada uma quantidade de solução hidrolisada de mel correspondente ao volume gasto na titulação a quente menos $1 \mathrm{ml}(\mathrm{Vq}-1)$. Só então, a caldeira foi acionada ao máximo e ao saírem os primeiros vapores a torneira da mesma foi fechada. Quando a solução da câmara, entrou em ebulição, o aquecimento foi reduzido à metade e 1,5 minuto foi aguardado. Após esse tempo, 3 gotas de azul de metileno $1 \%$ foram adicionadas, continuando-se a titulação, agora, gota-a-gota com a solução 
hidrolisada até o ponto de viragem (de azul para vermelho tijolo). Atingido o ponto de viragem, o volume gasto da referida solução foi anotado.

Antes da segunda titulação a frio, a câmara do Redutec foi cuidadosamente lavada com solução de $\mathrm{HCl} 5 \%$ e água destulada conforme citado anteriormente.

De posse dos valores dos volumes gastos de solução hidrolisada de mel nas duas titulações a frio, obteve-se a média dos mesmos sendo o valor de ART\% calculado através da seguinte fórmula:

$$
\mathrm{ART} \%=1 / \mathrm{q} \times(496,4404 / \mathrm{V} \times \mathrm{f}+0,605)
$$

onde:

$$
\begin{aligned}
\mathrm{q} & =\text { fator de diluição do mel }=0,275 \\
\mathrm{~V} & =\text { volume gasto da solução contida na bureta de Mohr } \\
\mathrm{f} & =\text { fator de correção do licor }
\end{aligned}
$$

\subsubsection{Açúcares Redutores (AR\%)}

Para a determinação dos açúcares redutores (AR\%), $40 \mathrm{ml}$ dos $50 \mathrm{ml}$ restantes da solução de mel $(1,1 \mathrm{~g} / 100 \mathrm{ml}$ de água destilada) foram transferidos para um balão volumétrico, de $200 \mathrm{ml}$, cujo volume foi completado com água destilada até a marca de aferição. Para a realização da titulação a quente, novamente visando-se o volume a ser gasto nas titulações a frio, a bureta de Mohr foi completada com a solução de mel e na câmara do Redutec foram colocados $10 \mathrm{ml}$ do licor de Fehling. A seqüência operacional com o aparelho foi idêntica à descrita para ART\%.

Analogamente, seguiram-se duas titulações a frio, cujos volumes gastos, também, não diferiram em mais de $0,2 \mathrm{ml}$. Então, novamente completou-se a bureta de Mohr com a solução de mel e $10 \mathrm{ml}$ do licor de Fehling foram colocados na câmara do Redutec. Ao licor foi acrescentado o volume de solução de mel correspondente ao volume gasto na titulação a quente menos $1 \mathrm{ml}(\mathrm{Vq}-1)$. Seguiram-se as mesmas operações no Redutec, conforme anteriormente especificado.

Anotados os volumes gastos nas titulações a frio e obtida a média desses volumes, calculou-se o $\mathrm{AR} \%$ através da seguinte fórmula: 


$$
\mathrm{AR} \%=1 / \mathrm{q} \times(496,4404 / \mathrm{V} \times f+0,605)
$$

onde, $\mathrm{q}=$ fator de diluição do mel $=0,22$

\subsubsection{Sacarose}

A quantidade de sacarose (\%) foi calculada através da diferença entre $\mathrm{ART} \%$ e AR\%, considerando-se, ainda, um fator de conversão de ART que é igual a 0,95. Esse fator de conversão foi obtido através do quociente entre o peso molecular da sacarose e o peso molecular total dos açúcares redutores.

$$
f=342 / 360
$$

Portanto, a sacarose calculada foi determinada pela seguinte fórmula:

$\%$ sacarose $_{\text {calc. }}=(\mathrm{ART} \%-\mathrm{AR} \%) \times 0,95$

Os dados observados, para fins de análise estatística, foram transformados para $\sqrt{(x+2)}$. 


\section{RESULTADOS E DISCUSSÃO}

\subsection{Umidade}

Os valores de umidade (\%) das amostras de méis de flores silvestres, de eucalipto, de laranjeira e de "méis" de exsudato de cana-de-açúcar são apresentados no Quadro II. 
Quadro II. Valores médios de umidade (\%) das amostras de méis de flores silvestres, de eucalipto, de laranjeira e de "méis" de exsudato de cana-de-açúcar coletadas em municípios do Estado de São Paulo.

\begin{tabular}{|c|c|c|c|c|c|c|c|c|c|c|c|}
\hline \multicolumn{6}{|c|}{ Silvestre } & \multicolumn{2}{|c|}{$\begin{array}{l}\text { Cana-de- } \\
\text { açúcar }\end{array}$} & \multicolumn{2}{|c|}{ Eucalipto } & \multicolumn{2}{|c|}{ Laranieira } \\
\hline S-01 & 17,5 & S-35 & 19,7 & S-69 & 17,8 & C-01 & 19,0 & $\mathrm{E}-01$ & 18,2 & $\mathrm{~L}-01$ & 17,7 \\
\hline S-02 & 21,0 & S-36 & 18,2 & $S-70$ & 20,4 & C-02 & 19,6 & $\mathrm{E}-02$ & 20,2 & $\mathrm{~L}-02$ & 17,0 \\
\hline $\mathrm{S}-03$ & 22,0 & S-37 & 17,4 & S-71 & 20,9 & $C-03$ & 17,3 & $\mathrm{E}-03$ & 17,3 & L-03 & 17,2 \\
\hline $\mathrm{S}-04$ & 17,5 & S-38 & 17,6 & $\mathrm{~S}-72$ & 19,7 & $C-04$ & 16,6 & E-04 & 17,8 & $\mathrm{~L}-04$ & 18,2 \\
\hline S-05 & 18,4 & S-39 & 16,4 & S-73 & 19,9 & $C-05$ & 21,2 & $\mathrm{E}-05$ & 19,2 & $\mathrm{~L}-05$ & 20,2 \\
\hline S-06 & 17,7 & S-40 & 19,2 & S-74 & 18,7 & & & E-06 & \begin{tabular}{|l|}
17,7 \\
\end{tabular} & L-06 & 17,7 \\
\hline S-07 & 20,0 & S-41 & 18,4 & S-75 & 18,1 & & & E-07 & 19,2 & L-07 & 17,3 \\
\hline S-08 & 19,3 & S-42 & 21,2 & S-76 & 20,0 & & & E-08 & 18,8 & L-08 & 16,6 \\
\hline S-09 & 20,4 & S-43 & 17,7 & S-77 & 18,7 & & & E-09 & 17,5 & L-09 & 19,0 \\
\hline S-10 & 18,6 & S-44 & 22,9 & $\mathrm{~S}-78$ & 20,8 & & & E-10 & 19,2 & $\mathrm{~L}-10$ & 17,5 \\
\hline $\mathrm{S}-11$ & 19,0 & S-45 & 17,6 & S-79 & 20,9 & & & E-11 & 16,6 & \begin{tabular}{|l|}
$\mathrm{L}-11$ \\
\end{tabular} & 17,2 \\
\hline $\mathrm{S}-12$ & 19,8 & S-46 & 18,4 & S-80 & 17,8 & & & $\mathrm{E}-12$ & 20,0 & $\mathrm{~L}-12$ & 17,5 \\
\hline $\mathrm{S}-13$ & 22,6 & S-47 & 16,6 & S-81 & 20,0 & & & E-13 & 20,0 & $\mathrm{~L}-13$ & 17,9 \\
\hline S-14 & 18,6 & S-48 & 19,9 & $\mathrm{~S}-82$ & 18,3 & & & E-14 & 18,8 & \begin{tabular}{|l|}
$\mathrm{L}-14$ \\
\end{tabular} & 21,5 \\
\hline S-15 & 18,0 & S-49 & 17,8 & $\mathrm{~S}-83$ & 17,9 & & & E-15 & 19,4 & $\mathrm{~L}-15$ & 17,6 \\
\hline S-16 & 19,2 & S-50 & 17,2 & S-84 & 20,0 & & & E-16 & \begin{tabular}{|l|}
18,4 \\
\end{tabular} & L-16 & 18,9 \\
\hline S-17 & 19,2 & S-51 & 17,9 & S-85 & 18,9 & & & E-17 & 18,2 & \begin{tabular}{|l|}
$L-17$ \\
\end{tabular} & 17,6 \\
\hline S-18 & 20,0 & S-52 & 19,5 & S-86 & 20,0 & & & $\mathrm{E}-18$ & 18,6 & L-18 & 18,2 \\
\hline S-19 & 21,9 & S-53 & 19,6 & S-87 & 18,8 & & & E-19 & 19,6 & $\mathrm{~L}-19$ & 18,5 \\
\hline $\mathrm{S}-20$ & 23,4 & S-54 & 19,4 & S-88 & 19,7 & & & E-20 & \begin{tabular}{|l|}
18,7 \\
\end{tabular} & $\mathrm{~L}-20$ & 18,8 \\
\hline $\mathrm{S}-21$ & 19,5 & S-55 & 18,3 & S-89 & 20,1 & & & E-21 & 18,6 & $\mathrm{~L}-21$ & 18,1 \\
\hline S-22 & 20,0 & S-56 & 18,3 & S-90 & 18,6 & & & E-22 & 17,9 & L-22 & 17,6 \\
\hline $\mathrm{S}-23$ & 19,7 & S-57 & 19,2 & S-91 & 18,3 & & & E-23 & 19,5 & L-23 & 19,9 \\
\hline $\mathrm{S}-24$ & 18,5 & S-58 & 17,4 & S-92 & 18,2 & & & E-24 & 18,7 & $\mathrm{~L}-24$ & 18,1 \\
\hline $\mathrm{S}-25$ & 17,1 & \begin{tabular}{|l} 
S-59 \\
\end{tabular} & 20,6 & $\mathrm{~S}-93$ & 18,4 & & & E-25 & 18,2 & $\mathrm{~L}-25$ & 18,1 \\
\hline S-26 & 20,4 & S- 60 & 16,8 & S-94 & 20,2 & & & E-26 & 19,4 & $\mathrm{~L}-26$ & 18,9 \\
\hline S-27 & 18,0 & S-61 & 17,8 & & & & & E-27 & 18,8 & $\mathrm{~L}-27$ & 18,4 \\
\hline $\mathrm{S}-28$ & 18,4 & S-62 & 20,1 & & & & & & & $\mathrm{~L}-28$ & 17,2 \\
\hline S-29 & 21,1 & $\mathrm{~S}-63$ & 20,4 & & & & & & & $\mathrm{~L}-29$ & 18,4 \\
\hline S-30 & 17,0 & S-64 & 20,6 & & & & & & & $\mathrm{~L}-30$ & 17,8 \\
\hline$S-31$ & 19,6 & S-65 & 16,0 & & & & & & & $L-31$ & 17,6 \\
\hline $\mathrm{S}-32$ & 20,2 & S-66 & 18,1 & & & & & & & $\mathrm{~L}-32$ & 16,4 \\
\hline S- 33 & 18,1 & S-67 & 19,5 & & & & & & & $\mathrm{~L}-33$ & 17,1 \\
\hline S- 34 & 19,7 & S-68 & 17,4 & & & & & & & L-34 & 20,5 \\
\hline
\end{tabular}


A descristalização de 5 amostras de méis de flores silvestres (S-36, S-37, S-55, S-86 e S-94) foi realizada através de aquecimento em banho-maria à temperatura de $46-50^{\circ} \mathrm{C}$ anteriormente à determinação da umidade. Entretanto, Frilli (1980) refere-se a um aquecimento na faixa de $38-40^{\circ} \mathrm{C}$. Pessotti ${ }^{4}$ recomendou uma descristalização por método térmico, através de banho-maria, para determinação da umidade. Thrasyvoulou et al. (1994) afirmaram que o aquecimento adequado não afeta a umidade do mel.

Cornejo (1988) afirma que uma maior umidade facilita o processo de fermentação e conseqüente deterioração do mel. No presente trabalho, observou-se que dez amostras de méis, que sofreram fermentação, também apresentaram valores de umidade mais altos, dentre os determinados. Entretanto, nem todas as amostras com alta porcentagem de umidade fermentaram durante o período observado.

Baseando-se na afirmação de Gómez et al. (1990) de que "mel" de canade-açúcar apresenta altos conteúdos de água comparativamente a outros méis, observouse que, embora os "méis" de exsudato de cana-de-açúcar, dessa pesquisa, tenham apresentado a segunda maior média $(18,4 \%)$, esse alto valor não se destacou com evidência dos valores médios dos demais méis, especialmente eucalipto e silvestre, pois apesar de distintos, os valores médios dos méis foram considerados estatisticamente iguais.

Amostras de méis de flores silvestres e de laranjeira, respectivamente, com a maior e a menor média de umidade, diferiram entre si, mas nenhuma delas diferiu das demais, ao nível de $5 \%$ de significância (Tabela 4 ).

${ }^{4}$ PESSOTTI, O. (Centro de Apicultura Tropical). Comunicação pessoal, 1994. 
Tabela 4. Valores médios de umidade $(\overline{\mathrm{m}})$, desvio padrão da média $(\mathrm{s}(\overline{\mathrm{m}}))$, intervalo de variação (i.v.) e número (n) de amostras de méis de flores silvestres, de eucalipto, de laranjeira e de "méis" de exsudato de cana-de-açúcar coletadas em municípios do Estado de São Paulo.

\begin{tabular}{lccc}
\hline \multicolumn{1}{c}{ Méis/'Méis" } & $\mathrm{n}$ & $\overline{\mathrm{m}} \pm \mathrm{s}(\overline{\mathrm{m}})$ & i.v. \\
\hline Silvestre & 94 & $19,1 \pm 0,15 \mathrm{a}$ & 16,0 a 23,4 \\
Cana-de-açúcar & 5 & $18,7 \pm 0,81 \mathrm{ab}$ & 16,6 a 21,2 \\
Eucalipto & 27 & $18,6 \pm 0,17 \mathrm{ab}$ & 16,6 a 20,2 \\
Laranjeira & 34 & $18,1 \pm 0,19 \mathrm{~b}$ & 16,4 a 21,5 \\
\hline
\end{tabular}

Médias seguidas de diferentes letras diferem estatisticamente, pelo teste de Tukey, ao nível de $5 \%$ de significância.

Papoff et al. (1988) obtiveram alto valor médio de umidade, $20,7 \%$, em méis da Somália, sendo que uma das amostras apresentou um valor igual a $23,8 \%$. Semelhantemente, Natarajan \& Yesuvadian (1978) encontraram mais da metade dos méis indianos com uma umidade mínima de $23 \%$, valores superiores aos do presente estudo.

Para amostras de méis de flores de Eucalyptus o valor médio de umidade determinado (18,6\%, Tabela 4) foi maior que o encontrado por Serra-i-Bonvehi \& Canas-Lloria (1988) para amostras de méis de mesma origem floral $(16,8 \%)$. Já, o valor médio de umidade de amostras de méis de flores de laranjeira $(18,1 \%)$ foi numericamente próximo a 17,6\% encontrado por Tabio et al. (1987) para amostras de méis de Citrus.

Moraes \& Mantovani (1986) também verificaram para amostras de méis de flores de laranjeira os menores valores médios de umidade $(15,6 \%)$ quando comparadas às demais amostras de méis por eles estudadas, e para amostras de "méis" de cana e de flores silvestres, valores de umidade inferiores aos encontrados no presente trabalho.

As amostras de méis das três floradas e de "méis" de exsudato de cana-deaçúcar, em valores médios de umidade, enquadraram-se nos limites estabelecidos pela legislação brasileira $(<20 \%)$. Entretanto, observa-se dentro de cada tipo de mel, certo número de amostras, calculado em termos de porcentagem, que não se encontra nesses limites permitidos (Figura 2).

Vit-Oliver (1988), estudando méis da Venezuela, verificou que $60,2 \%$ das amostras foi considerada aceitável pela legislação venezuelana. 

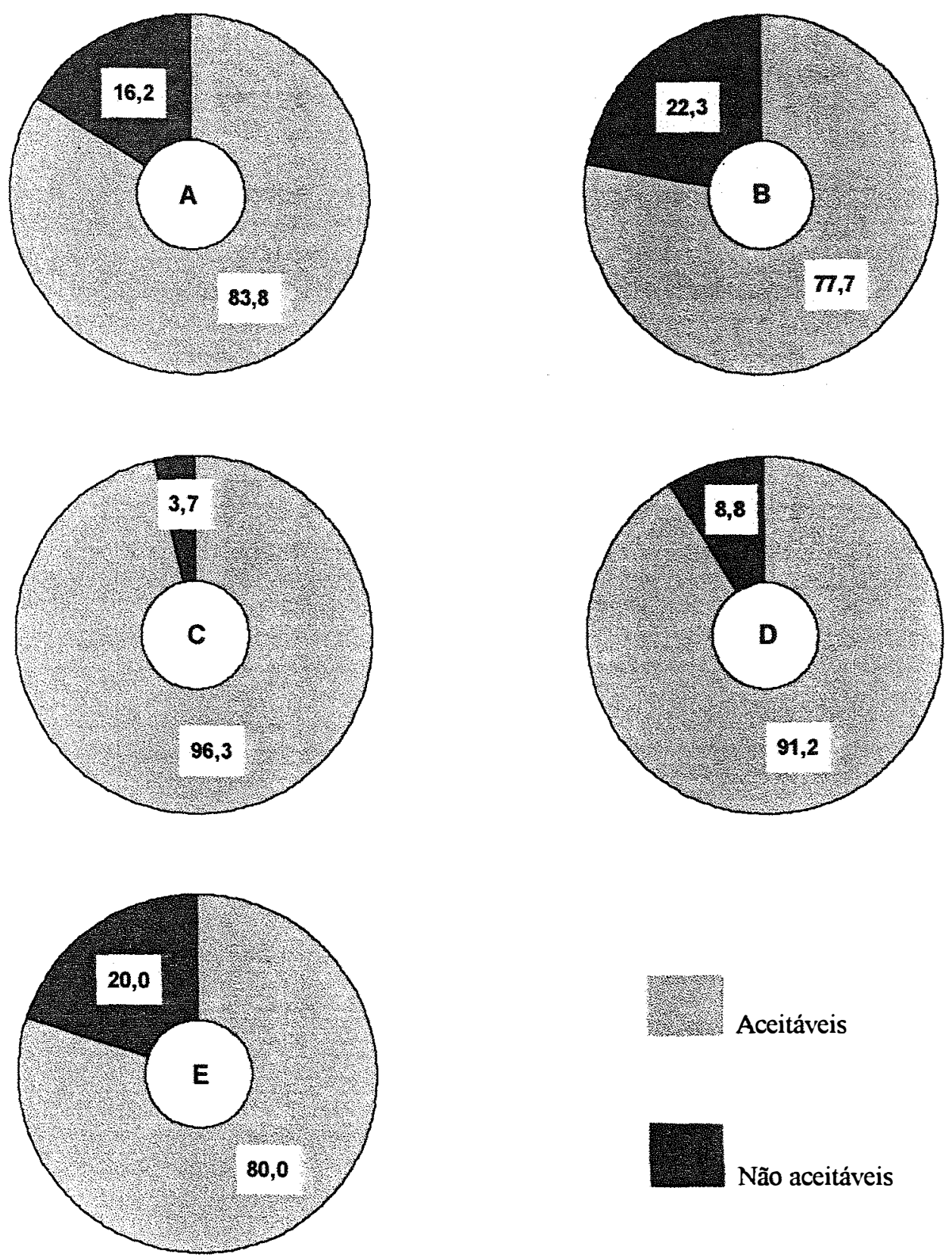

\section{Aceitáveis}

Figura 2. Porcentagens do conjunto de todas as amostras estudadas (A), de méis de flores silvestres (B), de eucalipto (C), de laranjeira (D) e de "méis" de exsudato de cana-de-açúcar (E), que são ou não aceitáveis segundo especificações da legislação brasileira para umidade. 


\subsection{Proteína}

Valores do teor de proteina $(\mathrm{ml})$ das amostras de méis de flores silvestres, de eucalipto, de laranjeira e de "méis" de exsudato de cana-de-açúcar são apresentados no Quadro III. 
Quadro III. Valores de proteína $(\mathrm{ml})$ das amostras de méis de flores silvestres, de eucalipto, de laranjeira e de "méis" de exsudato de cana-de-açúcar coletadas em municípios do Estado de São Paulo.

\begin{tabular}{|c|c|c|c|c|c|c|c|c|c|c|c|}
\hline \multicolumn{6}{|c|}{ Silvestre } & \multicolumn{2}{|c|}{$\begin{array}{l}\text { Cana-de- } \\
\text { açúcar }\end{array}$} & \multicolumn{2}{|c|}{ Eucalipto } & \multicolumn{2}{|c|}{ Laranjeira } \\
\hline S-01 & 0,4 & S-35 & 0,4 & S-69 & 0,4 & C-01 & 0,6 & E-01 & 0,4 & L-01 & 0,4 \\
\hline S-02 & 0,6 & $\mathrm{~S}-36$ & 0,4 & S-70 & 1,0 & C-02 & 1,4 & $\mathrm{E}-02$ & 0,2 & L-02 & 0,4 \\
\hline S-03 & 1,0 & S-37 & 0,6 & $S-71$ & 0,8 & C-03 & 1,4 & E-03 & 0,4 & L-03 & 0,2 \\
\hline S-04 & 0,6 & $\mathrm{~S}-38$ & 0,4 & S-72 & 0,6 & C-04 & 0,6 & E-04 & 0,6 & L-04 & 0,6 \\
\hline $\mathrm{S}-05$ & 0,6 & S-39 & 0,4 & S-73 & 0,4 & $\mathrm{C}-05$ & 0,6 & E-05 & 0,2 & L-05 & 0,8 \\
\hline S-06 & 0,6 & $\mathrm{~S}-40$ & 0,4 & S-74 & 0,4 & & & E-06 & 0,4 & L-06 & 0,4 \\
\hline S-07 & 0,4 & $\mathrm{~S}-41$ & 0,4 & S-75 & 0,2 & & & $\mathrm{E}-07$ & 0,4 & L-07 & 0,4 \\
\hline S-08 & 0,4 & $\mathrm{~S}-42$ & 0,6 & $\mathrm{~S}-76$ & 0,4 & & & E-08 & 0,6 & L-08 & 0,2 \\
\hline S-09 & 0,4 & $\mathrm{~S}-43$ & 0,6 & S-77 & 0,2 & & & E-09 & 0,4 & L-09 & 0,4 \\
\hline S-10 & 0,4 & $\mathrm{~S}-44$ & 0,6 & S-78 & 0,6 & & & $E-10$ & 0,8 & $\mathrm{~L}-10$ & 0,4 \\
\hline S-11 & 0,4 & $\mathrm{~S}-45$ & 0,8 & S-79 & 0,4 & & & $E-11$ & 0,6 & L-11 & 0,4 \\
\hline S-12 & 0,4 & S-46 & 0,8 & S-80 & 0,4 & & & E-12 & 0,6 & $\mathrm{~L}-12$ & 0,4 \\
\hline $\mathrm{S}-13$ & 0,2 & $\mathrm{~S}-47$ & 0,2 & S-81 & 0,4 & & & $E-13$ & 0,8 & L-13 & 0,6 \\
\hline S-14 & 0,4 & $\mathrm{~S}-48$ & 0,6 & S-82 & 0,2 & & & E-14 & 0,8 & L-14 & 0,4 \\
\hline S-15 & 1,0 & S-49 & 0,4 & S-83 & 0,6 & & & E-15 & 0,6 & L-15 & 0,4 \\
\hline $\mathrm{S}-16$ & 0,4 & $\mathrm{~S}-50$ & 0,2 & S-84 & 0,4 & & & $\mathrm{E}-16$ & 0,8 & L-16 & 0,2 \\
\hline S-17 & 0,2 & S-51 & 0,6 & S-85 & 0,4 & & & $E-17$ & 1,0 & L-17 & 0,6 \\
\hline S-18 & 0,6 & S-52 & 0,4 & S-86 & 0,8 & & & E-18 & 0,8 & L-18 & 0,8 \\
\hline S-19 & 0,4 & $\mathrm{~S}-53$ & 0,4 & S-87 & 0,4 & & & E-19 & 0,8 & L-19 & 0,4 \\
\hline S-20 & 1,6 & S-54 & 0,6 & S-88 & 1,2 & & & $\mathrm{E}-20$ & 1,0 & L-20 & 0,4 \\
\hline S-21 & 0,4 & S-55 & 0,4 & S-89 & 1,4 & & & $E-21$ & 0,6 & $L-21$ & 0,6 \\
\hline $\mathrm{S}-22$ & 0,2 & S-56 & 0,2 & S-90 & 0,4 & & & E-22 & 0,6 & $\mathrm{~L}-22$ & 0,8 \\
\hline $\mathrm{S}-23$ & 0,2 & S-57 & 0,6 & S-91 & 0,2 & & & $E-23$ & 0,6 & $\mathrm{~L}-23$ & 0,4 \\
\hline S-24 & 0,2 & S-58 & 0,4 & S-92 & 0,4 & & & $E-24$ & 0,8 & L-24 & 0,6 \\
\hline S-25 & 0,4 & S-59 & 0,4 & S-93 & 0,4 & & & E-25 & 0,0 & L-25 & 0,4 \\
\hline S-26 & 0,4 & $\mathrm{~S}-60$ & 0,4 & S-94 & 0,4 & & & E-26 & 0,4 & $\mathrm{~L}-26$ & 0,6 \\
\hline S-27 & 0,4 & S-61 & 0,8 & & & & & E-27 & 0,4 & L-27 & 0,4 \\
\hline $\mathrm{S}-28$ & 0,6 & S-62 & 0,8 & & & & & & & L-28 & 0,4 \\
\hline S-29 & 0,4 & S-63 & 1,0 & & & & & & & L-29 & 0,4 \\
\hline $\mathrm{S}-30$ & 0,2 & S-64 & 0,8 & & & & & & & L-30 & 0,4 \\
\hline $\mathrm{S}-31$ & 0,6 & S-65 & 0,4 & & & & & & & L-31 & 0,4 \\
\hline $\mathrm{S}-32$ & 0,6 & S-66 & 0,4 & & & & & & & L-32 & 0,4 \\
\hline $\mathrm{S}-33$ & 0,4 & S-67 & 0,4 & & & & & & & L-33 & 0,4 \\
\hline S-34 & 1,0 & S-68 & 0,4 & & & & & & & L-34 & 0,4 \\
\hline
\end{tabular}


Com relação ao conteúdo de proteína, segundo análise estatística, ao nível de 5\% de significância, amostras de "méis" de exsudato de cana-de-açúcar diferiram das outras amostra. Também apresentaram o valor médio mais elevado, seguidas, em ordem decrescente, pelas amostras de méis de flores de eucalipto, silvestres e de laranjeira (Tabela 5).

Tabela 5. Valores médios de proteína $(\overline{\mathrm{m}})$, desvio padrão da média $(\mathrm{s}(\overline{\mathrm{m}}))$, intervalo de variação (i.v.) e número(n) de amostras de méis de flores silvestres, de eucalipto, de laranjeira e de "méis" de exsudato de cana-de-açúcar coletadas em municípios do Estado de São Paulo.

\begin{tabular}{lccc}
\hline \multicolumn{1}{c}{ Méis/"Méis" } & $\mathrm{n}$ & $\overline{\mathrm{m}} \pm \mathrm{s}(\overline{\mathrm{m}})$ & i.v. \\
\hline Cana-de-açúcar & 5 & $0,9 \pm 0,20 \mathrm{a}$ & $0,6 \mathrm{a} 1,4$ \\
Eucalipto & 27 & $0,6 \pm 0,05 \mathrm{~b}$ & 0,0 a 1,0 \\
Silvestre & 94 & $0,5 \pm 0,03 \mathrm{~b}$ & $0,2 \mathrm{a} 1,6$ \\
Laranjeira & 34 & $0,4 \pm 0,02 \mathrm{~b}$ & $0.2 \mathrm{a} 0,8$ \\
\hline
\end{tabular}

Médias seguidas de diferentes letras diferem estatisticamente, pelo teste de Tukey, ao nível de $5 \%$ de significância.

Considerando-se os limites oficiais $(0,6$ a $3,0 \mathrm{ml})$, observa-se que, em valores médios, amostras de méis de eucalipto e de "méis" de exsudato de cana-de-açúcar estão de acordo com os valores permitidos, o mesmo não ocorrendo com amostras de méis de flores silvestres e de laranjeira.

As porcentagens das amostras de todo o Estado de São Paulo e de cada tipo, individualmente, que são ou não aceitáveis, segundo as especificações estabelecidas pela legislação brasileira para conteúdo de proteina, estão ilustrados na Figura 3. 

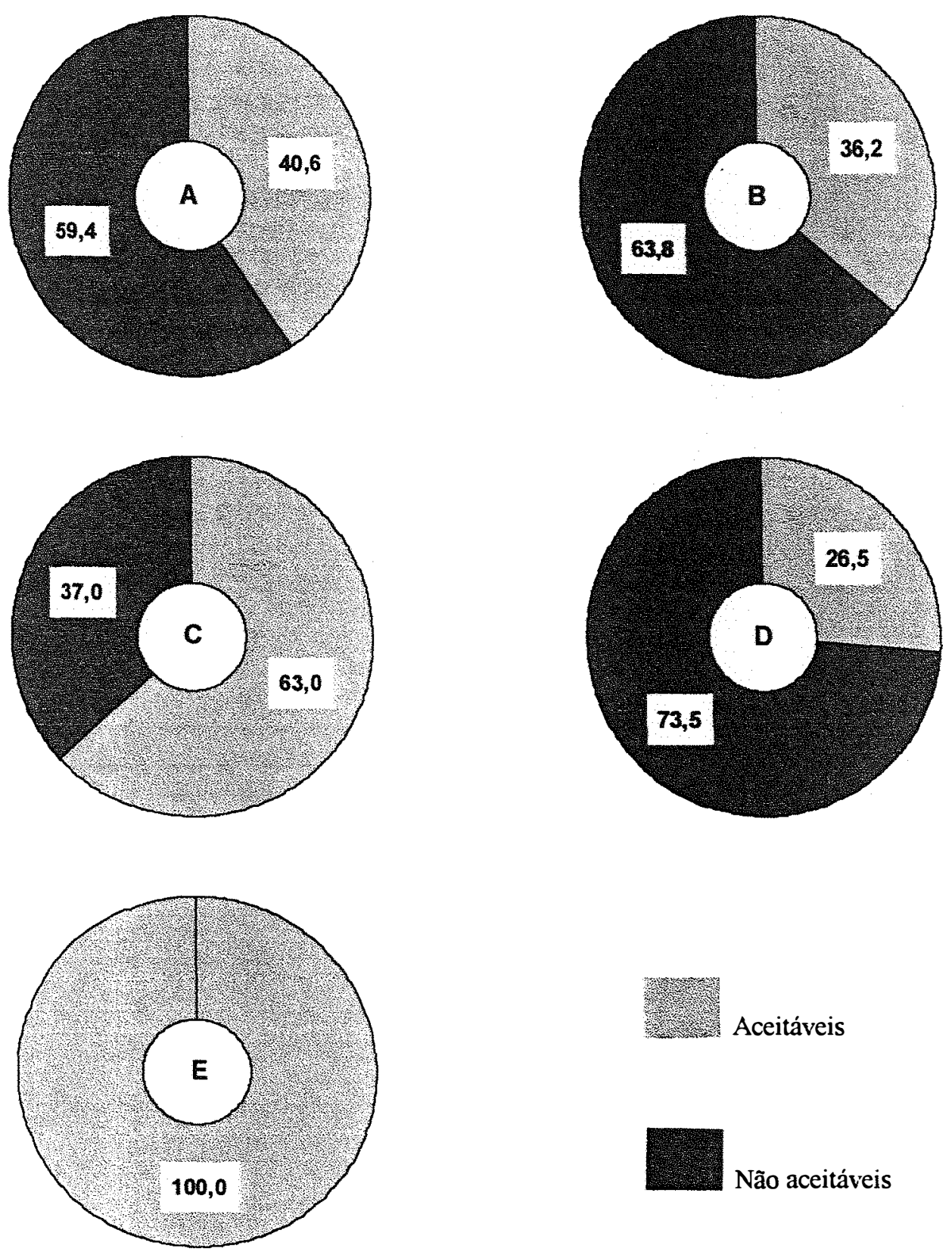

Figura 3. Porcentagens do conjunto de todas as amostras estudadas (A), de méis de flores silvestres (B), de eucalipto (C), de laranjeira (D) e de "méis" de exsudato de cana-de-açúcar (E) que são ou não aceitáveis segundo especificações da legislação brasileira para proteína. 
A reação de Lund, considerada um teste qualitativo, foi realizada por Bogdanov et al. (1987) como determinação preliminar de presença de proteina em amostras de méis suiços. No caso do presente trabalho, o referido parâmetro foi quantificado segundo o método considerado, para posterior comparação com os limites oficiais estabelecidos pela legislação.

Amostras de méis de flores de eucalipto apresentaram médias maiores que as de flores de laranjeira para proteina (Tabela 5), semelhantemente ao encontrado por Imperatriz-Fonseca et al. (1987) nas amostras de méis de Eucalyptus (1,92-2,76\%) e de Citrus $(1,58 \%)$ produzidas nas regiões norte, nordeste e sul do Brasil.

Amaral et al. (1986) trabalhando com amostras de méis de flores de eucalipto e de laranjeira encontraram, respectivamente, 2,54\% e 2,79\% em teor de proteína. Essa relação de valores foi inversa à constatada no presente trabalho, onde o teor de proteina das amostras de méis de flores de laranjeira foi menor que o encontrado para amostras de méis de flores de eucalipto.

Archenti (1984) verificou um baixo teor de proteina, 0,18\%, para méis argentinos.

\subsection{Indice de $\mathrm{pH}$}

Os valores de $\mathrm{pH}$ obtidos para as amostras de méis de flores silvestres, de eucalipto, de laranjeira e de "méis" de exsudato de cana-de-açúcar são apresentados no Quadro IV. 
Quadro IV. Valores de pH das amostras de méis de flores silvestres, de eucalipto, de laranjeira e de "méis" de exsudato de cana-de-açúcar coletadas em municípios do Estado de São Paulo.

\begin{tabular}{|c|c|c|c|c|c|c|c|c|c|c|c|}
\hline \multicolumn{6}{|c|}{ Silvestre } & \multicolumn{2}{|c|}{$\begin{array}{l}\text { Cana-de- } \\
\text { açúcar }\end{array}$} & \multicolumn{2}{|c|}{ Eucalipto } & \multicolumn{2}{|c|}{ Laranjeira } \\
\hline S-01 & 2,7 & $\mathrm{~S}-35$ & 3,0 & S-69 & 3,6 & $\mathrm{C}-01$ & 3,7 & E-01 & 3,6 & $\mathrm{~L}-01$ & 3,3 \\
\hline $\mathrm{S}-02$ & 3,4 & $\mathrm{~S}-36$ & 3,1 & $S-70$ & 3,4 & C-02 & 4,0 & E-02 & 3,4 & $\mathrm{~L}-02$ & 3,0 \\
\hline $\mathrm{S}-03$ & 2,8 & $\mathrm{~S}-37$ & 4,1 & S-71 & 3,5 & $\mathrm{C}-03$ & 3,8 & E-03 & 3,6 & L-03 & 3,1 \\
\hline $\mathrm{S}-04$ & 2,6 & $\mathrm{~S}-38$ & 3,8 & $S-72$ & 3,3 & C-04 & 4,1 & E-04 & 4,2 & L-04 & 3,0 \\
\hline S-05 & 2,9 & S-39 & 3,1 & S-73 & 3,0 & C-05 & 4,2 & E-05 & 3,9 & L-05 & 3,5 \\
\hline S-06 & 3,7 & $\mathrm{~S}-40$ & 2,8 & S-74 & 3,5 & & & E-06 & 4,0 & L-06 & 3,2 \\
\hline S-07 & 2,7 & S-41 & 2,8 & S-75 & 3,3 & & & E-07 & 3,5 & L-07 & 3,1 \\
\hline S-08 & 2,8 & $\mathrm{~S}-42$ & 3,0 & S-76 & 3,6 & & & E-08 & 3,6 & L-08 & 3,2 \\
\hline S-09 & 2,8 & $\mathrm{~S}-43$ & 3,2 & S-77 & 3,0 & & & E-09 & 3,5 & $\mathrm{~L}-09$ & 2,9 \\
\hline$S-10$ & 3,3 & $\mathrm{~S}-44$ & 2,7 & $\mathrm{~S}-78$ & 3,4 & & & E-10 & 3,0 & L-10 & 3,0 \\
\hline$S-11$ & 3,0 & $\mathrm{~S}-45$ & 2,8 & S-79 & 3,3 & & & E-11 & 3,8 & $\mathrm{~L}-11$ & 3,0 \\
\hline$S-12$ & 2,9 & S-46 & 2,9 & S-80 & 3,6 & & & $\mathrm{E}-12$ & 3,6 & $\mathrm{~L}-12$ & 3,1 \\
\hline$S-13$ & 2,8 & $\mathrm{~S}-47$ & 2,9 & S-81 & 3,4 & & & $E-13$ & 3,0 & $\mathrm{~L}-13$ & 3,2 \\
\hline S-14 & 3,6 & $S-48$ & 2,8 & S-82 & 2,8 & & & E-14 & 3,9 & L-14 & 2,7 \\
\hline S-15 & 3,4 & $\mathrm{~S}-49$ & 3,5 & S-83 & 3,3 & & & E-15 & 3,7 & $\mathrm{~L}-15$ & 2,9 \\
\hline S-16 & 3,1 & $S-50$ & 3,8 & S-84 & 3,1 & & & E-16 & 3,9 & L-16 & 3,0 \\
\hline$S-17$ & 3,3 & $S-51$ & 5,0 & S-85 & 3,4 & & & E-17 & 3,6 & $\mathrm{~L}-17$ & 3,0 \\
\hline$S-18$ & 3,3 & S-52 & 2,9 & S-86 & 3,8 & & & E-18 & 2,9 & $\mathrm{~L}-18$ & 3,1 \\
\hline$S-19$ & 3,1 & $\mathrm{~S}-53$ & 2,3 & S-87 & 3,4 & & & E-19 & 3,4 & L-19 & 3,1 \\
\hline S-20 & 3,2 & S-54 & 3,0 & S-88 & 3,4 & & & E-20 & 3,4 & $\mathrm{~L}-20$ & 2,9 \\
\hline$S-21$ & 3,1 & S-55 & 3,1 & S-89 & 3,0 & & & E-21 & 3,3 & L-21 & 2,8 \\
\hline S-22 & 2,9 & $S-56$ & 3,4 & $S-90$ & 2,8 & & & $\mathrm{E}-22$ & 3,4 & $\mathrm{~L}-22$ & 2,8 \\
\hline S-23 & 2,9 & S-57 & 3,5 & S-91 & 3,6 & & & E-23 & 3,4 & $\mathrm{~L}-23$ & 3,2 \\
\hline S-24 & 3,4 & S-58 & 3,1 & S-92 & 3,9 & & & $E-24$ & 3,5 & L-24 & 3,0 \\
\hline S-25 & 2,9 & S-59 & 2,9 & S-93 & 3,6 & & & E-25 & 5,1 & $\mathrm{~L}-25$ & 2,7 \\
\hline S-26 & 3,0 & $\mathrm{~S}-60$ & 3,4 & S-94 & 3,0 & & & E-26 & 4,1 & L-26 & 2,8 \\
\hline S-27 & 3,1 & $\mathrm{~S}-61$ & 3,4 & & & & & E-27 & 3,4 & L-27 & 2,8 \\
\hline$S-28$ & 3,2 & $\mathrm{~S}-62$ & 3,5 & & & & & & & $\mathrm{~L}-28$ & 2,9 \\
\hline S-29 & 2,9 & $\mathrm{~S}-63$ & 3,2 & & & & & & & $\mathrm{~L}-29$ & 2,8 \\
\hline$S-30$ & 3,0 & $\mathrm{~S}-64$ & 3,0 & & & & & & & L-30 & 2,8 \\
\hline$S-31$ & 3,4 & $S-65$ & 3,2 & & & & & & & $\mathrm{~L}-31$ & 3,0 \\
\hline$S-32$ & 3,7 & S-66 & 3,6 & & & & & & & $\mathrm{~L}-32$ & 3,1 \\
\hline S-33 & 4,2 & S-67 & 3,1 & & & & & & & $\mathrm{~L}-33$ & 2,7 \\
\hline S-34 & 2,9 & S-68 & 3,6 & & & & & & & L-34 & 2,9 \\
\hline
\end{tabular}


Quanto ao $\mathrm{pH}$, ao nível de 5\% de significância (Tabela 6), as amostras de "méis" de exsudato de cana-de-açúcar não diferiram estatisticamente das amostras de méis de flores de eucalipto. Porém, elas diferiram estatisticamente das amostras de méis de flores de laranjeira e silvestres, que apresentaram valores médios de $\mathrm{pH}$ mais baixos .

Tabela 6. Valores médios de $\mathrm{pH}(\overline{\mathrm{m}})$, desvio padrão da média $(\mathrm{s}(\overline{\mathrm{m}}))$, intervalo de variação (i.v.) e número (n) de amostras de méis de flores silvestres, de eucalipto, de laranjeira e de "méis" de exsudato de cana-de-açúcar coletadas em municípios do Estado de São Paulo.

\begin{tabular}{lccl}
\hline \multicolumn{1}{c}{ Méis/"Méis" } & $\mathrm{n}$ & $\overline{\mathbf{m}} \pm \mathbf{s}(\overline{\mathbf{m}})$ & i.v. \\
\hline Cana-de-açúcar & 5 & $4,0 \pm 0,10 \mathrm{a}$ & 3,7 a 4,2 \\
Eucalipto & 27 & $3,6 \pm 0,08 \mathrm{a}$ & 2,9 a 5,1 \\
Silvestre & 94 & $3,2 \pm 0,04 \mathrm{~b}$ & 2,3 a 5,0 \\
Laranjeira & 34 & $3,0 \pm 0,03 \mathrm{c}$ & 2,7 a 3,5 \\
\hline
\end{tabular}

Médias seguidas de diferentes letras diferem estatisticamente, pelo teste de Tukey, ao nível de $5 \%$ de significância.

Valores mais elevados de $\mathrm{pH}$, como obtidos para amostras de méis de flores silvestres e de eucalipto ( 5,1 e 5,0, respectivamente), também foram verificados por Frias-Tejera et al. (1990) que apresentaram um intervalo de variação para $\mathrm{pH}$ igual a $3,6-6,1$.

Dos materiais analisados, somente os de exsudato de cana-de-açúcar apresentaram pH médio igual a 4,0, numericamente mais próximo de 4,08, que foi o valor obtido por Fernández-Salguero \& Gómez (1992) para méis, e, considerado o menor dentre outros valores de $\mathrm{pH}$ dos alimentos analisados (azeite de oliva, café moído, coco ralado, entre outros mais).

As amostras de méis coletadas no Estado de São Paulo por Flechtmann et al. (1963) tiveram valores médios, referentes às amostras de méis de flores silvestres, de eucalipto, de laranjeira e de "méis" de exsudato de cana-de-açúcar, para $\mathrm{pH}(3,6 ; 4,1 ; 3,3$ e 4,3 , respectivamente) maiores que os obtidos na presente pesquisa.

Semelhantemente ao teor de proteína, os valores médios de $\mathrm{pH}$ apresentados pelas amostras de "méis" de cana-de-açúcar e de flores de eucalipto, respectivamente 4,0 e 3,6, estão enquadrados nas exigências da legislação. Amostras de 
méis de flores silvestres e de laranjeira com valores médios iguais a 3,2 e 3,0, respectivamente, não atingiram o limite mínimo exigido.

Todas as amostras de "méis" de exsudato de cana-de-açúcar apresentaram valor de pH dentro do que estabelece a legislação $(3,3-4,6)$. Entretanto, amostras de méis de flores silvestres, de eucalipto e de laranjeira apresentaram certo número de amostras, expresso em porcentagem, com valores de $\mathrm{pH}$ inferiores ou superiores aos números oficiais (Figura 4). 

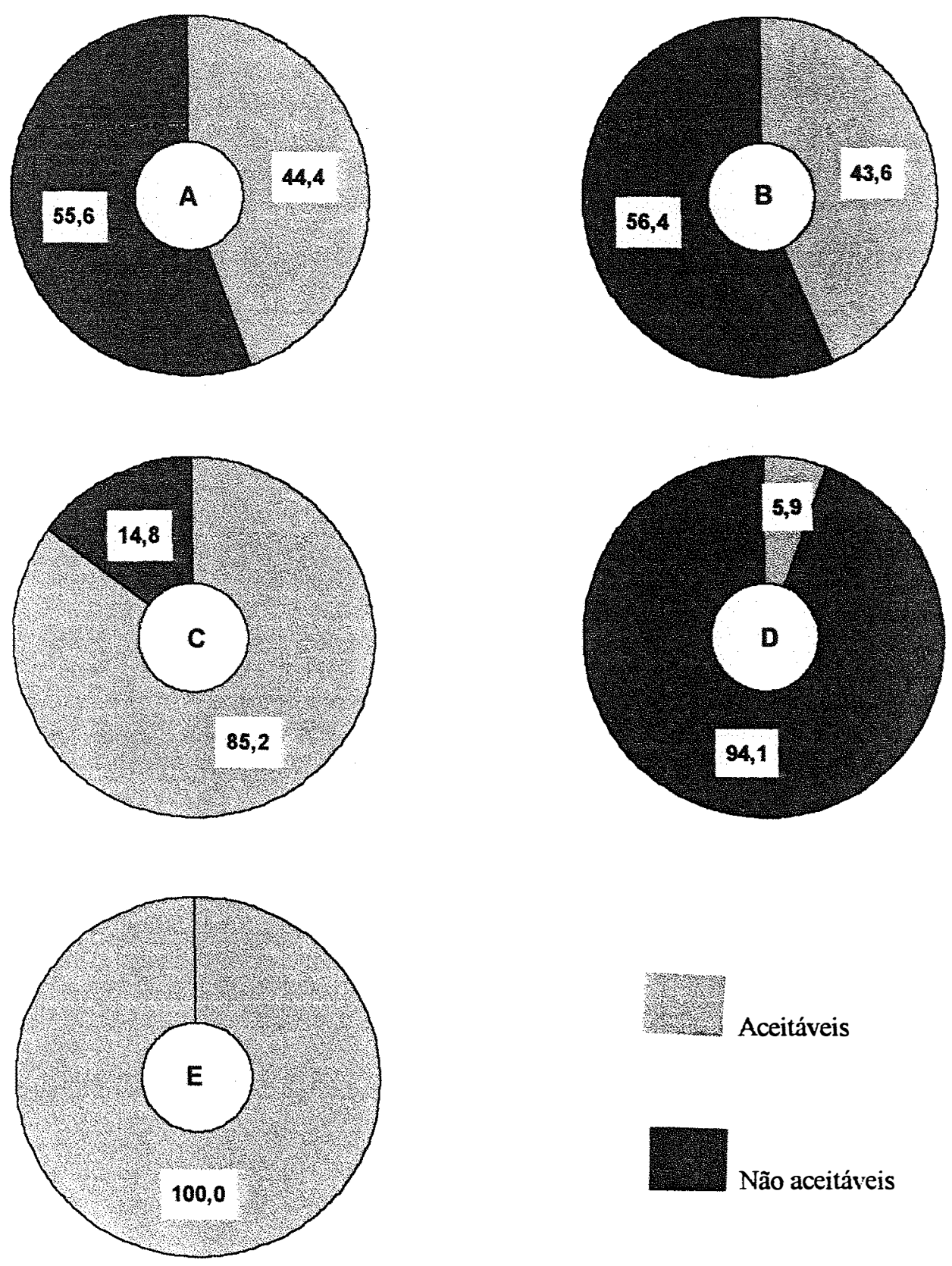

Figura 4. Porcentagens do conjunto de todas as amostras estudadas (A), de méis de flores silvestres (B), de eucalipto (C), de laranjeira (D) e de "méis" de exsudato de cana-de-açúcar (E) que são ou não aceitáveis segundo especificações da legislação brasileira para pH. 


\subsection{Acidez}

Os valores de acidez (meq $/ \mathrm{kg}$ ) das amostras de méis de flores silvestres, de eucalipto, de laranjeira e de "méis" de exsudato de cana-de-açúcar são apresentados no Quadro V. 
Quadro V. Valores de acidez (meq/kg) das amostras de méis de flores silvestres, de eucalipto, de laranjeira e de "méis" de exsudato de cana-de-açúcar coletadas em municípios do Estado de São Paulo.

\begin{tabular}{|c|c|c|c|c|c|c|c|c|c|c|c|}
\hline \multicolumn{6}{|c|}{ Silvestre } & \multicolumn{2}{|c|}{$\begin{array}{l}\text { Cana-de- } \\
\text { açúcar }\end{array}$} & \multicolumn{2}{|c|}{ Eucalipto } & \multicolumn{2}{|c|}{ Laranjeira } \\
\hline S-01 & 25,0 & $\mathrm{~S}-35$ & 18,5 & S-69 & 16,5 & $\mathrm{C}-01$ & 65,0 & $\mathrm{E}-01$ & 25,0 & L-01 & 19,5 \\
\hline S-02 & 43,5 & S-36 & 16,0 & S-70 & 35,0 & $\mathrm{C}-02$ & 74,5 & E-02 & 55,0 & $\mathrm{~L}-02$ & 22,0 \\
\hline S-03 & 53,0 & S-37 & 31,0 & S-71 & 41,5 & $\mathrm{C}-03$ & 66,0 & E-03 & 22,0 & $\mathrm{~L}-03$ & 21,0 \\
\hline S-04 & 20,5 & S-38 & 14,0 & $S-72$ & 41,0 & C- 04 & 44,5 & E-04 & 24,0 & $\mathrm{~L}-04$ & 30,5 \\
\hline S-05 & 24,0 & $\mathrm{~S}-39$ & 16,5 & S-73 & 35,0 & C-05 & 43,0 & E-05 & 30,0 & $\mathrm{~L}-05$ & 40,0 \\
\hline S-06 & 40,0 & $\mathrm{~S}-40$ & 22,0 & S-74 & 21,0 & & & E-06 & 19,0 & L-06 & 29,5 \\
\hline S-07 & 21,0 & S-41 & 14,0 & S-75 & 15,5 & & & E-07 & 35,0 & L-07 & 18,0 \\
\hline S-08 & 19,0 & $\mathrm{~S}-42$ & 47,0 & S-76 & 27,0 & & & E-08 & 54,5 & $\mathrm{~L}-08$ & 15,5 \\
\hline S-09 & 23,5 & $\mathrm{~S}-43$ & 27,0 & S-77 & 19,0 & & & E-09 & 50,0 & L-09 & 21,5 \\
\hline$S-10$ & 27,5 & $\mathrm{~S}-44$ & 50,5 & S-78 & 38,0 & & & $E-10$ & 46,0 & $\mathrm{~L}-10$ & 24,5 \\
\hline S-11 & 30,5 & $\mathrm{~S}-45$ & 27,5 & S-79 & 44,0 & & & E-11 & 18,5 & $\mathrm{~L}-11$ & 23,5 \\
\hline$S-12$ & 30,5 & S-46 & 25,5 & $\mathrm{~S}-80$ & 37,5 & & & $\mathrm{E}-12$ & 35,0 & $\mathrm{~L}-12$ & 22,0 \\
\hline$S-13$ & 22,5 & $\mathrm{~S}-47$ & 14,0 & $S-81$ & 47,0 & & & E-13 & 44,0 & $\mathrm{~L}-13$ & 20,5 \\
\hline$S-14$ & 23,5 & $\mathrm{~S}-48$ & 39,0 & S-82 & 28,5 & & & $\mathrm{E}-14$ & 29,0 & L-14 & 57,0 \\
\hline$S-15$ & 36,0 & $\mathrm{~S}-49$ & 30,5 & S-83 & 37,5 & & & E-15 & 32,0 & $\mathrm{~L}-15$ & 20,0 \\
\hline S-16 & 23,5 & S-50 & 21,5 & $\mathrm{~S}-84$ & 37,5 & & & E-16 & 23,5 & $\mathrm{~L}-16$ & 16,0 \\
\hline $\mathrm{S}-17$ & 20,5 & S-51 & 14,5 & S-85 & 28,0 & & & E-17 & 46,0 & $\mathrm{~L}-17$ & 18,0 \\
\hline S-18 & 36,0 & $\mathrm{~S}-52$ & 21,0 & S-86 & 35,0 & & & E-18 & 29,0 & $\mathrm{~L}-18$ & 25,0 \\
\hline S-19 & 46,0 & $\mathrm{~S}-53$ & 34,0 & S-87 & 36,0 & & & E-19 & 50,0 & $\mathrm{~L}-19$ & 25,0 \\
\hline $\mathrm{S}-20$ & 74,0 & S-54 & 30,0 & S-88 & 57,5 & & & $\mathrm{E}-20$ & 30,0 & $\mathrm{~L}-20$ & 35,0 \\
\hline S-21 & 24,5 & S-55 & 23,5 & S-89 & 75,5 & & & $\mathrm{E}-21$ & 34,0 & L-21 & 21,0 \\
\hline S-22 & 21,5 & S-56 & 20,0 & $S-90$ & 29,5 & & & $\mathrm{E}-22$ & 28,0 & $\mathrm{~L}-22$ & 20,5 \\
\hline S-23 & 16,0 & S-57 & 32,0 & S-91 & 20,0 & & & $\mathrm{E}-23$ & 36,0 & $\mathrm{~L}-23$ & 21,5 \\
\hline S-24 & 24,5 & S-58 & 15,5 & $S-92$ & 30,0 & & & E-24 & 39,0 & $\mathrm{~L}-24$ & 17,5 \\
\hline $\mathrm{S}-25$ & 19,5 & S-59 & 19,0 & S-93 & 25,0 & & & E-25 & 12,5 & $\mathrm{~L}-25$ & 18,5 \\
\hline S-26 & 22,5 & $S-60$ & 21,5 & S-94 & 45,0 & & & E-26 & 23,5 & $\mathrm{~L}-26$ & 27,0 \\
\hline S-27 & 25,0 & S-61 & 21,0 & & & & & E-27 & 43,5 & $\mathrm{~L}-27$ & 18,0 \\
\hline S-28 & 31,0 & S-62 & 44,0 & & & & & & & $\begin{array}{ll}\mathrm{L}-28 \\
\end{array}$ & 18,5 \\
\hline S-29 & 49,0 & S-63 & 45,5 & & & & & & & L-29 & 18,5 \\
\hline S-30 & 17,5 & S-64 & 39,5 & & & & & & & $L-30$ & 17,0 \\
\hline S-31 & 36,0 & S-65 & 14,0 & & & & & & & L-31 & 15,0 \\
\hline S-32 & 43,5 & S-66 & 35,0 & & & & & & & $\mathrm{~L}-32$ & 15,0 \\
\hline S-33 & 17,0 & S- 67 & 49,0 & & & & & & & $L-33$ & 20,5 \\
\hline S-34 & 27,0 & S-68 & 16,5 & & & & & & & L-34 & 22,5 \\
\hline
\end{tabular}


As amostras de "méis" de exsudato de cana-de-açúcar diferiram estatisticamente das demais ao nível de $5 \%$ de significância, apresentando o valor médio mais elevadọ. Amostras de méis de flores de laranjeira também diferiram das demais amostras, porém, apresentaram o menor valor médio de acidez. As amostras de méis de flores de eucalipto e silvestres não diferiram entre si (Tabela 7).

Tabela 7. Valores médios de acidez $(\overline{\mathrm{m}})$, desvio padrão da média $(\mathrm{s}(\overline{\mathrm{m}}))$, intervalo de variação (i.v.) e número (n) de amostras de méis de flores silvestres, de eucalipto, de laranjeira e de "méis" de exsudato de cana-de-açúcar coletadas em municípios do Estado de São Paulo.

\begin{tabular}{lccc}
\hline \multicolumn{1}{c}{ Méis/"Méis" } & $\mathrm{n}$ & $\overline{\mathrm{m}} \pm \mathrm{s}(\overline{\mathrm{m}})$ & i.v. \\
\hline Cana-de-açúcar & 5 & $58,6 \pm 6,29 \mathrm{a}$ & 43,0 a 74,5 \\
Eucalipto & 27 & $33,8 \pm 2,22 \mathrm{~b}$ & 12,5 a 55,0 \\
Silvestre & 94 & $30,1 \pm 1,29 \mathrm{~b}$ & 14,0 a 75,5 \\
Laranjeira & 34 & $22,8 \pm 1,40 \mathrm{c}$ & 15,0 a 57,0 \\
\hline
\end{tabular}

Médias seguidas de diferentes letras diferem estatisticamente, pelo teste de Tukey, ao nível de $5 \%$ de significância.

Com base nos valores médios, amostras de méis de flores de eucalipto, de laranjeira e silvestres são aceitáveis pela legislação, o mesmo não ocorrendo com amostras de "méis" de exsudato de cana-de-açúcar, as quais excederam o valor máximo de $40 \mathrm{meq} / \mathrm{kg}$, oficialmente estabelecido.

Todas as amostras de "méis" de exsudato de cana-de-açúcar não estão de acordo com os limites permitidos, como também, certa porcentagem das amostras de méis de flores de eucalipto, de laranjeira e silvestres (Figura 5).

Na pesquisa realizada por Vit-Oliver (1988), com relação à acidez, 25,5\% das amostras de méis venezuelanos não foi aceita segundo especificações oficiais do país.

A observação de Cornejo (1988) referente à relação acidez/fermentação, ou seja, que à uma alta acidez corresponde uma fermentação, também foi notada, no presente trabalho, com algumas amostras de méis que fermentaram (S-20, S-29, S-42, S44, S-67, E-19 e L-14). 

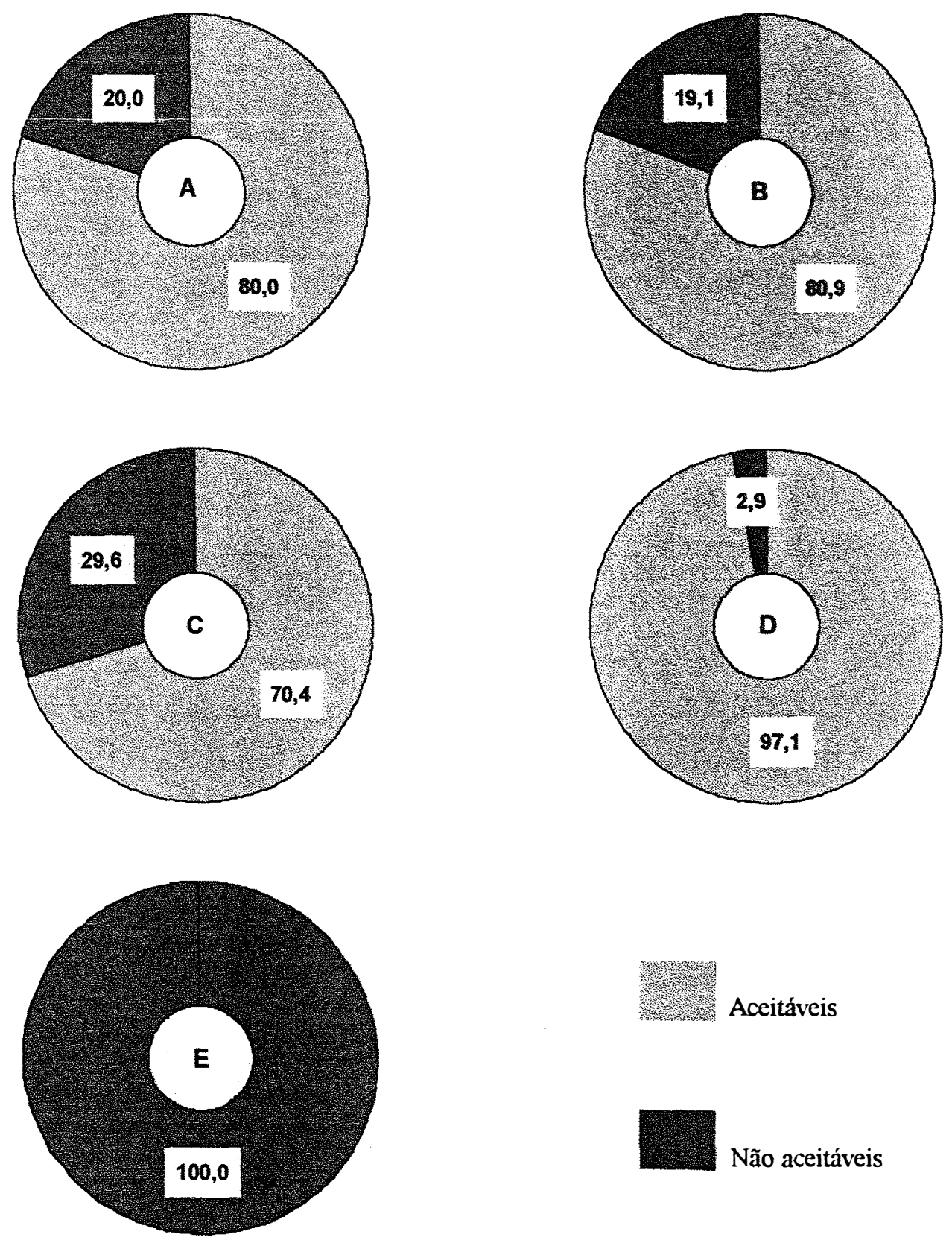

\section{Aceitáveis}

Figura 5. Porcentagens do conjunto de todas as amostras estudadas (A), de méis de flores silvestres (B), de eucalipto (C), de laranjeira (D) e de "méis" de exsudato de cana-de-açúcar (E), que são ou não aceitáveis segundo especificações da legislação brasileira para acidez. 


\section{5. Índice de formol}

Os valores de índice de formol $(\mathrm{ml} / \mathrm{kg})$ das amostras de méis de flores silvestres, de eucalipto, de laranjeira, de "méis" de exsudato de cana-de-açúcar são apresentados no Quadro VI. 
Quadro VI. Valores de índice de formol $(\mathrm{ml} / \mathrm{kg})$ das amostras de méis de flores silvestres, de eucalipto, de laranjeira e de "méis" de exsudato de cana-deaçúcar coletadas em municípios do Estado de São Paulo.

\begin{tabular}{|c|c|c|c|c|c|c|c|c|c|c|c|}
\hline \multicolumn{6}{|c|}{ Silvestre } & \multicolumn{2}{|c|}{$\begin{array}{l}\text { Cana-de- } \\
\text { açúcar }\end{array}$} & \multicolumn{2}{|c|}{ Eucalipto } & \multicolumn{2}{|c|}{ Laranjeira } \\
\hline S-01 & 7,0 & S-35 & 6,5 & S-69 & 9,5 & C-01 & 16,0 & E-01 & 6,0 & $\mathrm{~L}-01$ & 5,5 \\
\hline S-02 & 9,5 & S-36 & 6,0 & S-70 & 10,5 & C-02 & 21,5 & $E-02$ & 7,5 & $\mathrm{~L}-02$ & 5,5 \\
\hline S-03 & 11,5 & S-37 & 17,0 & S-71 & 14,0 & $\mathrm{C}-03$ & 10,0 & $\mathrm{E}-03$ & 6,0 & $\mathrm{~L}-03$ & 5,0 \\
\hline S-04 & 6,5 & S-38 & 7,5 & S-72 & 12,5 & C-04 & 11,0 & E-04 & 6,0 & $\mathrm{~L}-04$ & 6,5 \\
\hline S-05 & 8,0 & S-39 & 6,5 & S-73 & 14,5 & $\mathrm{C}-05$ & 11,0 & E-05 & 5,5 & $\mathrm{~L}-05$ & 7,5 \\
\hline S-06 & 13,5 & S-40 & 8,5 & S-74 & 9,5 & & & E-06 & 6,0 & L-06 & 8,0 \\
\hline S-07 & 8,5 & S-41 & 6,5 & S-75 & 8,0 & & & E-07 & 6,0 & $\mathrm{~L}-07$ & 5,5 \\
\hline S-08 & 6,5 & S-42 & 9,5 & S-76 & 11,5 & & & E-08 & 6,0 & $\mathrm{~L}-08$ & 5,0 \\
\hline S-09 & 8,5 & $S-43$ & 10,0 & S-77 & 9,0 & & & E-09 & 5,5 & L-09 & 6,0 \\
\hline$S-10$ & 9,5 & S-44 & 13,5 & S-78 & 13,5 & & & E-10 & 7,0 & $\mathrm{~L}-10$ & 6,5 \\
\hline$S-11$ & 8,0 & S-45 & 9,5 & S-79 & 20,5 & & & E-11 & 5,5 & $\mathrm{~L}-11$ & 6,0 \\
\hline$S-12$ & 9,5 & S-46 & 11,5 & $\mathrm{~S}-80$ & 13,0 & & & E-12 & 12,5 & $\mathrm{~L}-12$ & 6,0 \\
\hline$S-13$ & 5,5 & S-47 & 8,0 & S-81 & 13,0 & & & E-13 & 9,5 & L-13 & 6,5 \\
\hline$S-14$ & 7,5 & S-48 & 11,5 & $\mathrm{~S}-82$ & 6,0 & & & E-14 & 6,0 & L-14 & 8,0 \\
\hline$S-15$ & 12,5 & S-49 & 9,5 & S-83 & 15,0 & & & E-15 & 6,0 & $\mathrm{~L}-15$ & 5,5 \\
\hline S-16 & 7,50 & S-50 & 10,0 & S-84 & 15,5 & & & E-16 & 5,5 & $\mathrm{~L}-16$ & 5,0 \\
\hline S-17 & 8,0 & S-51 & 11,0 & $\mathrm{~S}-85$ & 11,0 & & & E-17 & 8,5 & $\mathrm{~L}-17$ & 5,0 \\
\hline S-18 & 8,5 & S-52 & 8,0 & S-86 & 10,0 & & & E-18 & 8,0 & L-18 & 7,0 \\
\hline S-19 & 9,5 & S-53 & 13,0 & S-87 & 11,5 & & & E-19 & 8,0 & L-19 & 8,0 \\
\hline$S-20$ & 10,0 & S-54 & 11,5 & S-88 & 16,0 & & & E-20 & 7,0 & $\mathrm{~L}-20$ & 9,5 \\
\hline S-21 & 7,5 & S-55 & 10,0 & S-89 & 14,0 & & & E-21 & 7,0 & $\mathrm{~L}-21$ & 6,5 \\
\hline S-22 & 6,0 & S-56 & 8,5 & S-90 & 10,0 & & & $E-22$ & 7,5 & $\mathrm{~L}-22$ & 7,5 \\
\hline $\mathrm{S}-23$ & 6,0 & S-57 & 16,0 & S-91 & 8,0 & & & E-23 & 8,5 & $\mathrm{~L}-23$ & 6,0 \\
\hline $\mathrm{S}-24$ & 9,0 & S-58 & 8,0 & S-92 & 9,0 & & & E-24 & 8,0 & $\mathrm{~L}-24$ & 6,0 \\
\hline$S-25$ & 6,0 & S-59 & 7,0 & S-93 & 10,0 & & & E-25 & 5,0 & $\mathrm{~L}-25$ & 5,5 \\
\hline$S-26$ & 6,5 & S-60 & 10,0 & S-94 & 16,5 & & & E-26 & 6,5 & $\mathrm{~L}-26$ & 7,0 \\
\hline S-27 & 10,0 & S-61 & 10,5 & & & & & $\mathrm{E}-27$ & 6,0 & $\mathrm{~L}-27$ & 6,0 \\
\hline S-28 & 10,0 & S-62 & 14,5 & & & & & & & $\mathrm{~L}-28$ & 6,0 \\
\hline S-29 & 9,0 & S-63 & 12,0 & & & & & & & $\mathrm{~L}-29$ & 6,5 \\
\hline$S-30$ & 5,0 & S-64 & 11,0 & & & & & & & $\mathrm{~L}-30$ & 6,0 \\
\hline$S-31$ & 8,0 & S-65 & 8,5 & & & & & & & $\mathrm{~L}-31$ & 6,5 \\
\hline S-32 & 18,0 & S-66 & 13,0 & & & & & & & $\mathrm{~L}-32$ & 6,0 \\
\hline$S-33$ & 6,0 & S-67 & 15,0 & & & & & & & L-33 & 6,0 \\
\hline S-34 & 6,0 & S-68 & 10,5 & & & & & & & $\mathrm{~L}-34$ & 7,0 \\
\hline
\end{tabular}


De acordo com os dados estatísticos, o índice de formol das amostras de "méis" de exsudato de cana-de-açúcar diferiram das demais, assim como as amostras de méis de flores silvestres. Amostras de méis de flores de eucalipto e de laranjeira não diferiram estatisticamente entre si, ao nível de significância indicado. Os valores médios de índice de formol mais baixos foram apresentados pelas amostras de méis de flores de eucalipto e de laranjeira e, o mais alto, por amostras de "méis" de exsudato de cana-deaçúcar, seguidas pelas amostras de méis de flores silvestres (Tabela 8).

Tabela 8. Valores médios de índice de formol $(\overline{\mathrm{m}})$, desvio padrão da média $(\mathrm{s}(\overline{\mathrm{m}}))$, intervalo de variação (i.v.) e número (n) de amostras de méis de flores silvestres, de eucalipto, de laranjeira e de "méis" de exsudato de cana-deaçúcar coletadas em municípios do Estado de São Paulo.

\begin{tabular}{lccc}
\hline \multicolumn{1}{c}{ Méis/"Méis" } & $\mathrm{n}$ & $\overline{\mathrm{m}} \pm \mathrm{s}(\overline{\mathrm{m}})$ & i.v. \\
\hline Cana-de-açúcar & 5 & $13,9 \pm 2,17 \mathrm{a}$ & 10,0 a 21,5 \\
Silvestre & 94 & $10,1 \pm 0,33 \mathrm{~b}$ & 5,0 a 20,5 \\
Eucalipto & 27 & $6,9 \pm 0,31 \mathrm{c}$ & 5,0 a 12,5 \\
Laranjeira & 34 & $6,3 \pm 0,17 \mathrm{c}$ & 5,0 a 9,5 \\
\hline
\end{tabular}

Médias seguidas de diferentes letras diferem estatisticamente, pelo teste de Tukey, ao nível de $5 \%$ de significância.

Temiz (1983), estudando 47 amostras de méis, das quais 10 de Citrus apresentou uma faixa de 4,5-8,6 ml/kg para índice de formol, cujos valores foram equivalentes aos encontrados para amostras de méis de flores de laranjeira da presente pesquisa.

Comparando-se os valores médios de índice de formol de cada tipo de amostra com a faixa de valores permitida oficialmente $(4,5 \mathrm{a} 15,0 \mathrm{ml})$ verifica-se que todas as amostras encontram-se dentro deste intervalo. Entretanto, se analisadas individualmente, nota-se que amostras de méis de flores silvestres e de "méis" de exsudato de cana-de-açúcar apresentam certa porcentagem de amostras fora dos padrões oficiais (Figura 6). 

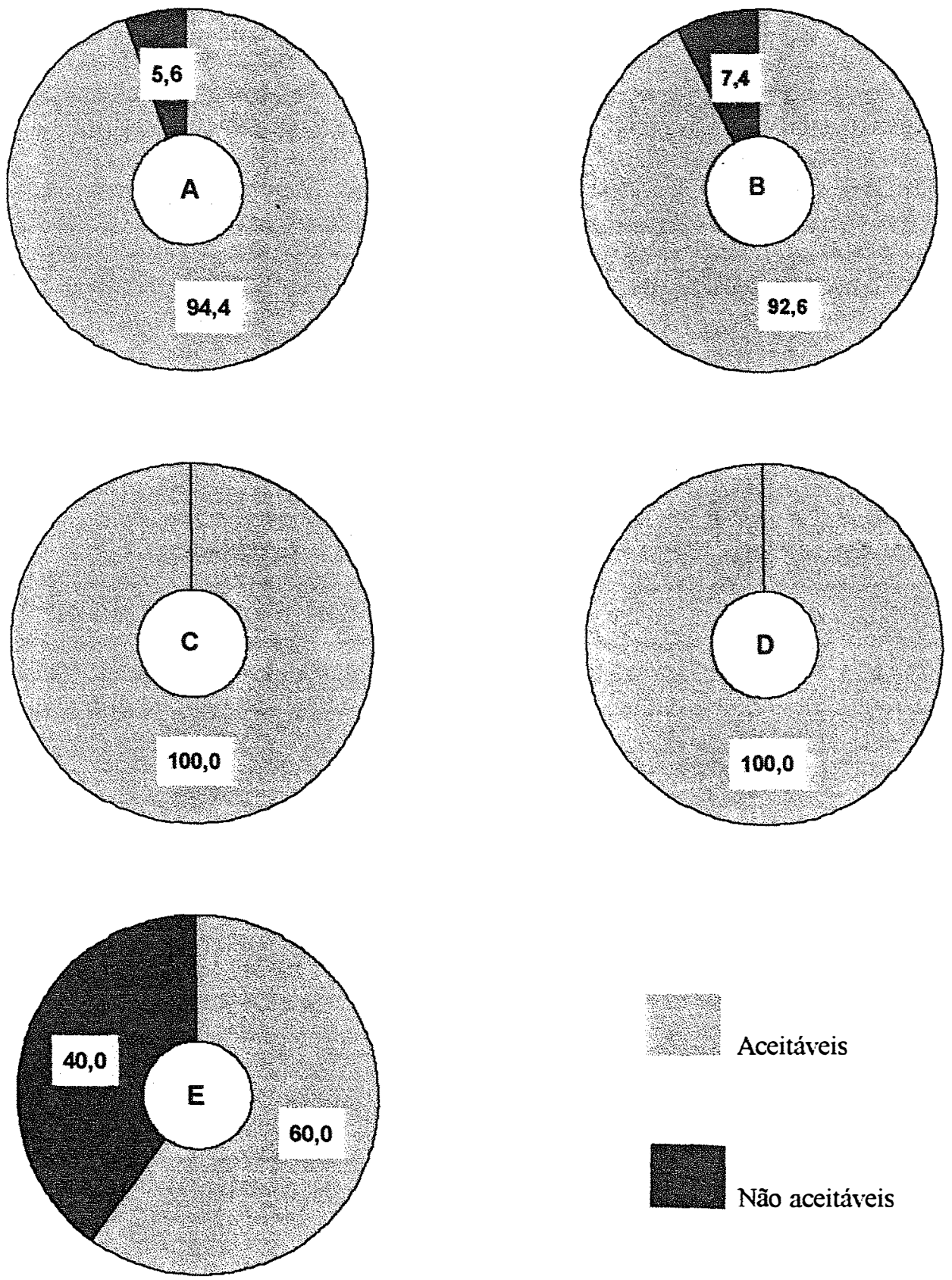

Figura 6. Porcentagens do conjunto de todas as amostras estudadas (A), de méis de flores silvestres (B), de eucalipto (C), de laranjeira (D) e de "méis" de exsudato de cana-de-açúcar (E) que são ou não aceitáveis segundo especificações da legislação brasileira para índice de formol. 


\section{6. Índice de diastase}

Os valores de índice de diastase das amostras de méis de flores silvestres, de eucalipto, de laranjeira e de "méis" de exsudato de cana-de-açúcar são apresentados no Quadro VII. 
Quadro VII. Valores de índice de diastase das amostras de mëis de flores silvestres, de eucalipto, de laranjeira e de "méis" de exsudato de cana-de-açúcar coletadas em municípios do Estado de São Paulo.

\begin{tabular}{|c|c|c|c|c|c|c|c|c|c|c|c|}
\hline \multicolumn{6}{|c|}{ Silvestre } & \multicolumn{2}{|c|}{$\begin{array}{l}\text { Cana-de- } \\
\text { açúcar }\end{array}$} & \multicolumn{2}{|c|}{ Eucalipto } & \multicolumn{2}{|c|}{ Laranjeira } \\
\hline S-01 & 5,0 & S-35 & 13,9 & S-69 & 10,9 & $\mathrm{C}-01$ & 5,0 & $\mathrm{E}-01$ & 17,9 & $\mathrm{~L}-01$ & 5,0 \\
\hline S- 02 & 29,4 & S-36 & 6,5 & $S-70$ & 17,9 & C-02 & 29,4 & E-02 & 23,8 & $\mathrm{~L}-02$ & 6,5 \\
\hline $\mathrm{S}-03$ & 13,9 & S-37 & 17,9 & $S-71$ & 17,9 & $\mathrm{C}-03$ & 8,3 & $\mathrm{E}-03$ & 10,9 & L-03 & 8,3 \\
\hline S-04 & 8,3 & S-38 & 5,0 & $S-72$ & 29,4 & $\mathrm{C}-04$ & 17,9 & E-04 & 17,9 & L-04 & 8,3 \\
\hline S-05 & 17,9 & S-39 & 13,9 & S-73 & 23,8 & C-05 & 29,4 & E-05 & 13,9 & L-05 & 17,9 \\
\hline S-06 & 23,8 & S-40 & 10,9 & S-74 & 13,9 & & & E-06 & 13,9 & L-06 & 8,3 \\
\hline S-07 & 13,9 & $S-41$ & 6,5 & S-75 & 8,3 & & & E-07 & 10,9 & L-07 & 8,3 \\
\hline S-08 & 8,3 & S-42 & 23,8 & $S-76$ & 17,9 & & & E-08 & 6,5 & $\mathrm{~L}-08$ & 10,9 \\
\hline S-09 & 8,3 & S-43 & 38,5 & S-77 & 6,5 & & & E-09 & 5,0 & L-09 & 10,9 \\
\hline S-10 & 17,9 & S-44 & 17,9 & $S-78$ & 29,4 & & & E-10 & 10,9 & L-10 & 8,3 \\
\hline S-11 & 17,9 & S-45 & 13,9 & S-79 & 38,5 & & & E-11 & 13,9 & L-11 & 8,3 \\
\hline $\mathrm{S}-12$ & 13,9 & S-46 & 17,9 & S-80 & 29,4 & & & $E-12$ & 10,9 & $\mathrm{~L}-12$ & 8,3 \\
\hline S-13 & 8,3 & S-47 & 10,9 & S-81 & 13,9 & & & E-13 & 23,8 & $\mathrm{~L}-13$ & 5,0 \\
\hline S-14 & 17,9 & S-48 & 13,9 & S-82 & 5,0 & & & E-14 & 17,9 & $\mathrm{~L}-14$ & 10,9 \\
\hline S-15 & 23,8 & S-49 & 13,9 & S-83 & 23,8 & & & E-15 & 17,9 & $\mathrm{~L}-15$ & 8,3 \\
\hline S-16 & 10,9 & S-50 & 29,4 & S-84 & 23,8 & & & $E-16$ & 23,8 & $\mathrm{~L}-16$ & 8,3 \\
\hline S-17 & 8,3 & S-51 & 38,5 & S-85 & 13,9 & & & E-17 & 13,9 & $\mathrm{~L}-17$ & 8,3 \\
\hline S-18 & 29,4 & S-52 & 5,0 & S-86 & 38,5 & & & E-18 & 13,9 & $\mathrm{~L}-18$ & 5,0 \\
\hline S-19 & 17,9 & S-53 & 38,5 & S-87 & 10,9 & & & E-19 & 23,8 & $\mathrm{~L}-19$ & 10,9 \\
\hline S-20 & 10,9 & S-54 & 17,9 & S-88 & 38,5 & & & $\mathrm{E}-20$ & 10,9 & $\mathrm{~L}-20$ & 13,9 \\
\hline S-21 & 13,9 & S-55 & 8,3 & S-89 & 29,4 & & & E-21 & 13,9 & $\mathrm{~L}-21$ & 13,9 \\
\hline S-22 & 13,9 & S-56 & 8,3 & S-90 & 5,0 & & & $\mathrm{E}-22$ & 17,9 & $\mathrm{~L}-22$ & 10,9 \\
\hline S-23 & 8,3 & S-57 & 17,9 & S-91 & 10,9 & & & $\mathrm{E}-23$ & 17,9 & $\mathrm{~L}-23$ & 10,9 \\
\hline S-24 & 17,9 & S-58 & 17,9 & S-92 & 17,9 & & & $\mathrm{E}-24$ & 23,8 & $\mathrm{~L}-24$ & 8,3 \\
\hline S-25 & 10,9 & S-59 & 6,5 & S-93 & 17,9 & & & E-25 & 23,8 & $\mathrm{~L}-25$ & 10,9 \\
\hline S-26 & 8,3 & S-60 & 23,8 & S-94 & 38,5 & & & E-26 & 17,9 & $\mathrm{~L}-26$ & 10,9 \\
\hline S-27 & 10,9 & S-61 & 17,9 & & & & & $E-27$ & 8,3 & $\mathrm{~L}-27$ & 6,5 \\
\hline S-28 & 13,9 & S-62 & 29,4 & & & & & & & $\mathrm{~L}-28$ & 10,9 \\
\hline S-29 & 10,9 & S-63 & 13,9 & & & & & & & $\mathrm{~L}-29$ & 8,3 \\
\hline $\mathrm{S}-30$ & 10,9 & S-64 & 29,4 & & & & & & & L-30 & 10,9 \\
\hline S-31 & 23,8 & S-65 & 17,9 & & & & & & & $\mathrm{~L}-31$ & 6,5 \\
\hline S-32 & 17,9 & S-66 & 17,9 & & & & & & & $\mathrm{~L}-32$ & 5,0 \\
\hline S-33 & 13,9 & S-67 & 23,8 & & & & & & & L-33 & 8,3 \\
\hline S-34 & 13,9 & S-68 & 13,9 & & & & & & & L-34 & 17,9 \\
\hline
\end{tabular}


A menor média para índice de diastase foi verificada em amostras de méis de flores de laranjeira, seguindo-se em ordem crescente, amostras de méis de flores de eucalipto, silvestres e de "méis" de exsudato de cana-de-açúcar. Entretanto, de acordo com a análise estatística, não houve diferença significativa entre as amostras analisadas, ao nível de 5\% de significância (Tabela 9).

Tabela 9. Valores médios de índice de diastase $(\overline{\mathrm{m}})$, desvio padrão da média $(\mathrm{s}(\overline{\mathrm{m}}))$, intervalo de variação (i.v.) e número (n) de amostras de méis de flores silvestres, de eucalipto, de laranjeira e "méis" de exsudato de cana-de-açúcar coletadas em municípios do Estado de São Paulo.

\begin{tabular}{lccc}
\hline \multicolumn{1}{c}{ Méis/"Méis" } & $\mathrm{n}$ & $\overline{\mathrm{m}} \pm \mathrm{s}(\overline{\mathrm{m}})$ & i.v. \\
\hline Silvestre & 94 & $17,3 \pm 0,93 \mathrm{a}$ & 5,0 a 38,5 \\
Cana-de-açúcar & 5 & $18,0 \pm 5,11 \mathrm{a}$ & 5,0 a 29,4 \\
Eucalipto & 27 & $15,8 \pm 1,08 \mathrm{a}$ & 5,0 a 23,8 \\
Laranjeira & 34 & $9,4 \pm 0,54 \mathrm{a}$ & 5,0 a 17,9 \\
\hline
\end{tabular}

Médias seguidas de mesma letra não diferem estatisticamente, pelo teste de Tukey, ao nível de $5 \%$ de significância.

Observando os valores médios obtidos, verifica-se que todas as citadas amostras estão de acordo com as normas oficiais, ou seja, todas são superiores a 8, valor mínimo estabelecido pela legislação. Entretanto, segundo a mesma legislação para o índice de diastase, tolera-se o valor mínimo 3 se o valor de $\mathrm{HMF}$ for inferior a $15 \mathrm{mg} / \mathrm{kg}$.

Desse modo, dentro de cada tipo de amostra, valores inferiores a 8 com HMF < 15 são considerados aceitáveis. Assim, 7 amostras de méis ( E-9, L-1, L-13, L32, S-1, S-38, S-62) e uma de "méis" de exsudato de cana-de-açúcar (C-1) não atingiram o valor mínimo exigido para índice de diastase.

As porcentagens de amostras estudadas consideradas aceitáveis ou não segundo as especificações oficiais são apresentada na Figura 7. 

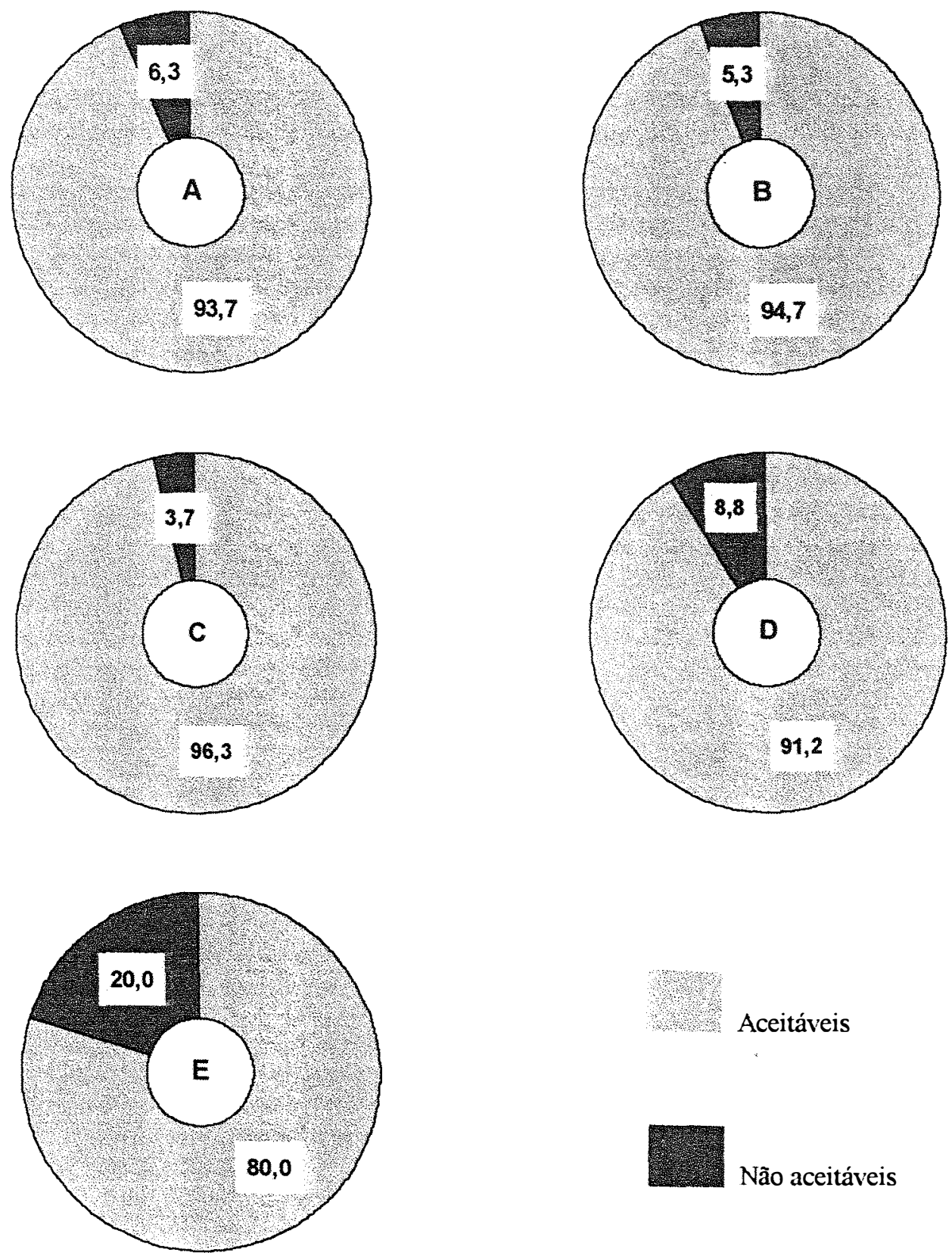

\section{Aceitáveis}

Não aceitáveis

Figura 7. Porcentagens do conjunto de todas as amostras estudadas (A), de méis de flores silvestres (B), de eucalipto (C), de laranjeira (D) e de "méis" de exsudato de cana-de-açúcar (E), que são ou não aceitáveis segundo especificações da legislação brasileira para índice de diastase. 
Persano-Oddo et al. (1990) encontraram valores muito diferentes de índice de diastase dentro da mesma florada, como por exemplo, amostras de méis de Castanea com valores 10 ou 43 . O mesmo, também foi verificado na mesma proporção, com as amostras de méis de flores silvestres na presente pesquisa; em amostras de "méis" de exsudato de cana-de-açúcar, de flores de eucalipto e de laranjeira, também, foi observada, em menor amplitude, essa diferença entre o valor mínimo e máximo obtidos para índice de diastase.

O fato de méis de citros apresentarem baixo valor de diastase, conforme afirmado por White et al. ${ }^{5}$, citados por Thrasyvoulou (1986), também foi constatado com as amostras de méis de flores de laranjeira estudadas, que apresentaram um índice de diastase igual a 9,4 (Tabela 9).

Balenovic et al. (1988) obtiveram $54,4 \%$, das 44 amostras de méis analisadas, em conformidade com os padrões oficiais considerados; e, Vit-Oliver (1988) obteve $66 \%$ das amostras de méis dentro das especificações do padrão venezuelano.

\subsection{Hidroximetilfurfural}

As quantidades de HMF $(\mathrm{mg} / \mathrm{kg})$ das amostras de méis de flores silvestres, de eucalipto, de laranjeira e de "méis" de exsudato de cana-de-açúcar são apresentadas no Quadro VIII.

\footnotetext{
${ }^{5}$ WHITE, J.W.; KUSHNIR, I.; SUBERS, M. Effect of storage and processing temperatures on honey quality. Fed Technol., v.18, n.4, p. 153-6, 1964.
} 
Quadro VIII. Valores de HMF $(\mathrm{mg} / \mathrm{kg}$ ) das amostras de méis de flores silvestres, de eucalipto, de laranjeira e de "méis" de exsudato de cana-de-açúcar coletadas em municípios do Estado de São Paulo.

\begin{tabular}{|c|c|c|c|c|c|c|c|c|c|c|c|}
\hline \multicolumn{6}{|c|}{ Silvestre } & \multicolumn{2}{|c|}{$\begin{array}{l}\text { Cana-de- } \\
\text { açúcar }\end{array}$} & \multicolumn{2}{|c|}{ Eucalipto } & \multicolumn{2}{|c|}{ Laranjeira } \\
\hline S-01 & 27,2 & S-35 & 10,3 & S-69 & 12,0 & $\mathrm{C}-01$ & 242,6 & $\mathrm{E}-01$ & 20,0 & $\mathrm{~L}-01$ & 38,3 \\
\hline S-02 & 8,1 & S-36 & 6,6 & S-70 & 28,4 & C-02 & 29,4 & $\mathrm{E}-02$ & 12,6 & $\mathrm{~L}-02$ & 11,8 \\
\hline S-03 & 36,3 & S-37 & 3,4 & S-71 & 15,0 & $C-03$ & 239,9 & $\mathrm{E}-03$ & 16,3 & $\mathrm{~L}-03$ & 9,3 \\
\hline S-04 & 24,6 & S-38 & 20,0 & $S-72$ & 14,6 & C-04 & 15,4 & $\mathrm{E}-04$ & 5,8 & $\mathrm{~L}-04$ & 10,7 \\
\hline S-05 & 11,1 & S-39 & 12,8 & S-73 & 10,9 & C-05 & 15,9 & $\mathrm{E}-05$ & 15,1 & $\mathrm{~L}-05$ & 14,8 \\
\hline S-06 & 9,2 & S-40 & 15,3 & S-74 & 6,5 & & & $\mathrm{E}-06$ & 5,0 & $\mathrm{~L}-06$ & 11,6 \\
\hline S-07 & 13,5 & S-41 & 11,8 & S-75 & 21,9 & & & E-07 & 5,7 & $\mathrm{~L}-07$ & 8,3 \\
\hline S-08 & 10,7 & S-42 & 11,1 & S-76 & 10,0 & & & E-08 & 11,9 & $\mathrm{~L}-08$ & 8,2 \\
\hline S-09 & 9,9 & $\mathrm{~S}-43$ & 11,5 & S-77 & 10,8 & & & E-09 & 27,9 & $\mathrm{~L}-09$ & 11,2 \\
\hline S-10 & 10,9 & S-44 & 4,9 & S-78 & 21,4 & & & E-10 & 12,0 & $\mathrm{~L}-10$ & 24,6 \\
\hline S-11 & 12,4 & $\mathrm{~S}-45$ & 22,7 & S-79 & 10,2 & & & E-11 & 5,9 & $\mathrm{~L}-11$ & 12,7 \\
\hline$S-12$ & 11,4 & S-46 & 19,1 & S-80 & 33,6 & & & $\mathrm{E}-12$ & 19,9 & $\mathrm{~L}-12$ & 19,4 \\
\hline$S-13$ & 1,9 & S-47 & 14,2 & S-81 & 22,7 & & & E-13 & 5,4 & $\mathrm{~L}-13$ & 20,2 \\
\hline S-14 & 10,9 & S-48 & 20,2 & S-82 & 64,6 & & & $\mathrm{E}-14$ & 2,0 & $\mathrm{~L}-14$ & 7,9 \\
\hline$S-15$ & 12,0 & S-49 & 34,2 & S-83 & 49,8 & & & E-15 & 2,2 & $\mathrm{~L}-15$ & 10,2 \\
\hline S-16 & 19,4 & $\mathrm{~S}-50$ & 4,9 & S-84 & 25,5 & & & E-16 & 2,0 & $\mathrm{~L}-16$ & 8,6 \\
\hline S-17 & 11,6 & S-51 & 1,0 & S-85 & 17,7 & & & E-17 & 207,2 & $\mathrm{~L}-17$ & 14,3 \\
\hline S-18 & 6,4 & S-52 & 15,2 & S-86 & 59,5 & & & E-18 & 10,7 & $\mathrm{~L}-18$ & 13,0 \\
\hline$S-19$ & 11,3 & S-53 & 19,9 & S-87 & 35,9 & & & E-19 & 9,1 & L-19 & 11,6 \\
\hline $\mathrm{S}-20$ & 10,0 & S-54 & 18,0 & S-88 & 17,9 & & & E-20 & 36,1 & $\mathrm{~L}-20$ & 16,4 \\
\hline$S-21$ & 19,6 & S-55 & 19,5 & S-89 & 16,0 & & & $\mathrm{E}-21$ & 6,0 & $\mathrm{~L}-21$ & 10,0 \\
\hline $\mathrm{S}-22$ & 12,6 & S-56 & 15,4 & S-90 & 122,0 & & & E-22 & 5,8 & $\mathrm{~L}-22$ & 15,4 \\
\hline S-23 & 9,7 & S-57 & 31,6 & S-91 & 17,9 & & & E-23 & 8,1 & $\mathrm{~L}-23$ & 19,8 \\
\hline S-24 & 10,9 & S-58 & 14,4 & S-92 & 16,8 & & & E-24 & 6,4 & $\mathrm{~L}-24$ & 16,5 \\
\hline S-25 & 19,5 & S-59 & 6,9 & S-93 & 19,1 & & & E-25 & 0,3 & $\mathrm{~L}-25$ & 10,2 \\
\hline S-26 & 4,1 & S-60 & 12,7 & S-94 & 25,7 & & & E-26 & 1,5 & $\mathrm{~L}-26$ & 15,7 \\
\hline S-27 & 24,9 & S-61 & 18,9 & & & & & E-27 & 10,5 & $\mathrm{~L}-27$ & 13,1 \\
\hline S-28 & 23,6 & S-62 & 36,9 & & & & & & & $\mathrm{~L}-28$ & 15,6 \\
\hline S-29 & 17,8 & S-63 & 58,9 & & & & & & & $\mathrm{~L}-29$ & 13,6 \\
\hline S-30 & 10,2 & S-64 & 6,1 & & & & & & & $\mathrm{~L}-30$ & 15,4 \\
\hline S-31 & 19,3 & S-65 & 11,3 & & & & & & & $\mathrm{~L}-31$ & 13,9 \\
\hline S-32 & 20,2 & S-66 & 17,0 & & & & & & & $\mathrm{~L}-32$ & 45,3 \\
\hline $\mathrm{S}-33$ & 59,5 & S-67 & 33,7 & & & & & & & L-33 & 13,9 \\
\hline $\mathrm{S}-34$ & 13,7 & S-68 & 11,5 & & & & & & & L-34 & 13,7 \\
\hline
\end{tabular}


Pelos resultados médios submetidos à análise estatística (Tabela 10), somente amostras de "méis" de exsudato de cana-de-açúcar diferiram significativamente das demais, ao nivel de $5 \%$ de significância, com uma média muito elevada devido a duas amostras (C-1 e C-3) que apresentaram valores excessivamente altos de HMF.

Tabela 10. Valores médios de $\mathrm{HMF}(\overline{\mathrm{m}})$, desvio padrão da média $(\mathrm{s}(\overline{\mathrm{m}}))$, intervalo de variação (i.v.) e número (n) de amostras de méis de flores silvestres, de eucalipto, de laranjeira e de "méis" de exsudato de cana-de-açúcar coletadas em municípios do Estado de São Paulo.

\begin{tabular}{lccc}
\hline \multicolumn{1}{c}{ Méis/"Méis" } & $\mathrm{n}$ & $\overline{\mathrm{m}} \pm \mathrm{s}(\overline{\mathrm{m}})$ & i.v. \\
\hline Cana-de-açúcar & 5 & $108,6 \pm 54,20 \mathrm{a}$ & 15,4 a 242,6 \\
Silvestre & 94 & $19,3 \pm 1,69 \mathrm{~b}$ & 1,0 a 122,0 \\
Laranjeira & 34 & $15,2 \pm 1,33 \mathrm{~b}$ & 7,9 a 45,3 \\
Eucalipto & 27 & $17,4 \pm 7,42 \mathrm{~b}$ & 0,3 a 207,2 \\
\hline
\end{tabular}

Médias seguidas de diferentes letras diferem estatisticamente, pelo teste de Tukey, ao nivel de $5 \%$ de significância.

Em termos médios, somente as amostras de "méis" de exsudato de canade-açúcar excederam os limites permitidos pela legislação $(40 \mathrm{mg} / \mathrm{kg})$. Mais uma vez, analisando os valores de HMF das amostras de um mesmo tipo, verifica-se que, em todas, existe uma porcentagem não enquadrada nessas especificações (Figura 8). 

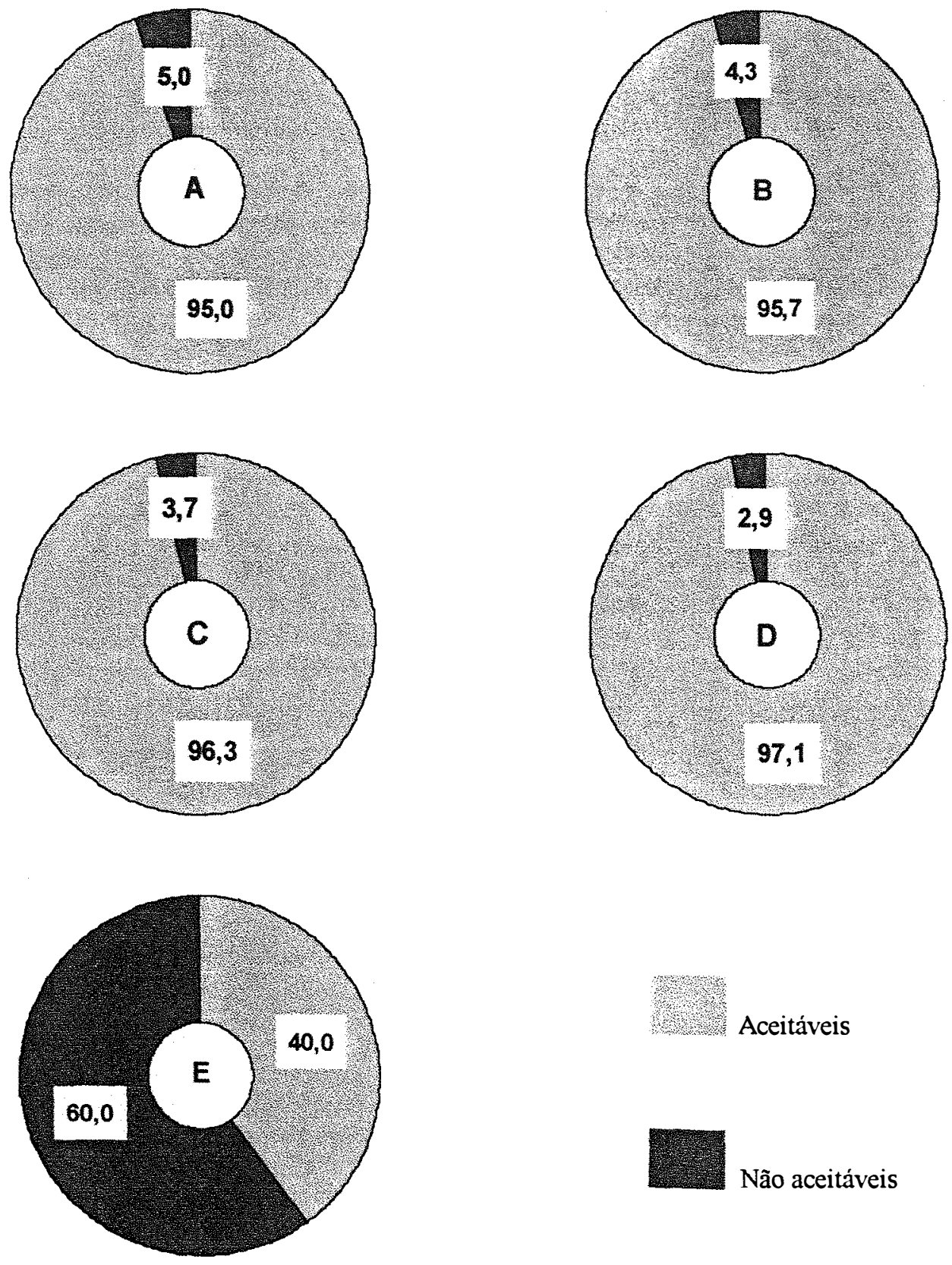

Figura 8. Porcentagens do conjunto de todas as amostras estudadas (A), de méis de flores silvestres (B), de eucalipto (C), de laranjeira (D) e de "méis" de exsudato de cana-de-açúcar (E), que são ou não aceitáveis segundo especificações da legislação brasileira para HMF. 
Colin et al. (1986) verificaram que $88 \%$ das 67 amostras de mel francês analisadas estavam dentro dos padrões estabelecidos para HMF. No estudo realizado por Thrasyvoulou et al. (1982) tal porcentagem para amostras de méis enquadradas nos limites oficiais europeus para HMF foi de $18 \%$. Bricage (1989) obteve $81,8 \%$ das amostras estudadas de acordo com o estabelecido pelo padrão europeu. Balenovic et al. (1988) tiveram 54,4\% das amostras analisadas dentro das especificações oficiais. Semelhantemente, porém segundo a legislação venezuelana, Vit-Oliver (1988) verificou que $56,8 \%$ das amostras de méis estudadas estava enquadrada nos limites estabelecidos.

Piazza \& Accorti (1983) também obtiveram 100\% das amostras de méis produzidas por pequenos apicultores, $97 \%$ das adquiridas em cooperativas, $76 \%$ das adquiridas no comércio e $55 \%$ das importadas pela Itália enquadradas nos limites estabelecidos pela EEC.

Mesallan \& El-Shaarawy (1987) afirmaram que o aquecimento severo é suficiente para inativar a enzima diastase. É devido a isso que méis submetidos a inadequado aquecimento apresentam baixos valores de índice de diastase e altos de $\mathrm{HMF}$, como por exemplo as amostras S-90, C-1, C-3, E-17 e L-32 da presente pesquisa.

$\mathrm{O}$ nível de HMF em méis recém-colhidos é muito baixo, mas aumenta significativamente através de armazenamento, aquecimento ou adição de açúcares invertidos, Doner ${ }^{6}$ citado por Mesallan \& El-Shaarawy (1987). Assim, de acordo com o exposto, as amostras analisadas, com HMF excessivamente altos, poderiam ser sido submetidas inadequadamente a qualquer um dos referidos processos.

Quanto à relação inversamente proporcional existente entre valores de $\mathrm{pH}$ e HMF citada por Thrasyvoulou (1986), somente amostras de méis de flores de eucalipto, quando comparadas com as de flores silvestres, é que essa proporção foi notada.

Semelhantemente aos valores excessivamente altos de HMF obtidos para as amostras de méis de flores silvestres ( $\mathrm{S}-90=122,0 \mathrm{mg} / \mathrm{kg}$ ), de "méis" de exsudato de cana-de-açúcar (C-1=242,6 e C-3=239,9 mg $/ \mathrm{kg}$ ) e de flores de eucalipto (E-17=207,2 $\mathrm{mg} / \mathrm{kg}$ ), Mesallan \& El-Shaarawy -(1987) também determinaram para méis importados pela Arábia Saudita, altos valores, como 120,$0 ; 149,0 ; 160,0$ e $164,0 \mathrm{mg} / \mathrm{kg}$. Reio \& Englund (1985) também determinaram um alto valor de HMF, em méis importados pela Suíça, correspondente a $95,2 \mathrm{mg} / \mathrm{kg}$.

${ }^{6}$ DONER, L.W. The sugars of honey, a review. J. Sci. Food Agr., v.28, p. 443-56, 1977. 
Valores excessivamente altos de HMF, observados para algumas amostras de méis, elevaram o valor médio desse parâmetro; entretanto, não considerando esses dados discrepantes, observa-se que as amostras de méis restantes de flores silvestres, de eucalipto e de "méis" de exsudato de cana-de-açúcar apresentaram, respectivamente, os seguintes valores médios: $19,6 \mathrm{mg} / \mathrm{kg}, 10,1 \mathrm{mg} / \mathrm{kg}$ e $20,2 \mathrm{mg} / \mathrm{kg}$, que são aceitos pela legislação para HMF.

Amostras de méis de flores silvestres apresentaram não só, altos valores médios de umidade, como também de HMF, conforme relatado por Thrasyvoulou (1986).

\subsection{Açúcares redutores}

Os teores de açúcares redutores (\%), expressos em glicose, das amostras de méis de flores silvestres, de eucalipto, de laranjeira e de "méis" de exsudato de canade-açúcar são apresentados no Quadro IX. 
Quadro IX. Valores de açúcares redutores (\%), expressos em glicose, das amostras de méis de flores silvestres, de eucalipto, de laranjeira e de "méis" de exsudato de cana-de-açúcar coletadas em municípios do Estado de São Paulo.

\begin{tabular}{|c|c|c|c|c|c|c|c|c|c|c|c|}
\hline \multicolumn{6}{|c|}{ Silvestre } & \multicolumn{2}{|c|}{$\begin{array}{l}\text { Cana-de- } \\
\text { açúcar }\end{array}$} & \multicolumn{2}{|c|}{ Eucalipto } & \multicolumn{2}{|c|}{ Laranjeira } \\
\hline S-01 & 66,4 & $S-35$ & 77,4 & S-69 & 76,5 & $\overline{C-01}$ & 68,5 & $\mathrm{E}-01$ & 74,3 & $\overline{L-01}$ & 73,4 \\
\hline S- 02 & 70,5 & S-36 & 76,9 & S-70 & 75,2 & C-02 & 66,0 & E-02 & 74,5 & $\mathrm{~L}-02$ & 75,5 \\
\hline S-03 & 67,8 & S-37 & 73,4 & S-71 & 73,2 & C-03 & 67,8 & E-03 & 72,3 & $\mathrm{~L}-03$ & 76,4 \\
\hline S- 04 & 74,9 & S-38 & 71,6 & S-72 & 71,2 & C-04 & 70,2 & E-04 & 69,8 & L-04 & 74,1 \\
\hline S- 05 & 76,0 & S-39 & 74,1 & S-73 & 70,1 & C-05 & 68,6 & E-05 & 73,8 & $\mathrm{~L}-05$ & 68,6 \\
\hline S-06 & 72,2 & $S-40$ & 79,8 & S-74 & 72,8 & & & E-06 & 74,4 & L-06 & 74,4 \\
\hline S-07 & 77,4 & S-41 & 73,5 & S-75 & 75,6 & & & E-07 & 74,0 & L-07 & 76,4 \\
\hline S-08 & 77,0 & S-42 & 68,2 & S-76 & 74,3 & & & E-08 & 74,4 & $\mathrm{~L}-08$ & 76,5 \\
\hline S-09 & 75,3 & S-43 & 74,3 & S-77 & 78,6 & & & E-09 & 77,1 & $\mathrm{~L}-09$ & 72,8 \\
\hline S-10 & 76,1 & S-44 & 70,9 & S-78 & 70,5 & & & E-10 & 71,2 & $\mathrm{~L}-10$ & 72,8 \\
\hline S-11 & 75,4 & S-45 & 74,8 & S-79 & 67,9 & & & $E-11$ & 72,7 & $\mathrm{~L}-11$ & 75,5 \\
\hline$S-12$ & 77,5 & S-46 & 74,2 & S-80 & 70,1 & & & E-12 & 69,2 & $\mathrm{~L}-12$ & 74,5 \\
\hline S-13 & 72,2 & S-47 & 74,5 & S-81 & 70,0 & & & $E-13$ & 73,0 & $\mathrm{~L}-13$ & 74,3 \\
\hline S-14 & 73,8 & S-48 & 72,9 & S-82 & 53,2 & & & E-14 & 74,0 & $\mathrm{~L}-14$ & 72,8 \\
\hline S-15 & 73,8 & S-49 & 70,5 & S-83 & 72,8 & & & $E-15$ & 73,0 & $\mathrm{~L}-15$ & 75,2 \\
\hline S-16 & 75,2 & S-50 & 70,5 & S-84 & 67,8 & & & E-16 & 70,4 & $\mathrm{~L}-16$ & 72,8 \\
\hline S-17 & 76,6 & S-51 & 69,3 & S-85 & 72,4 & & & E-17 & 67,7 & L-17 & 74,3 \\
\hline S-18 & 70,5 & S-52 & 70,8 & S-86 & 69,6 & & & E-18 & 76,2 & $\mathrm{~L}-18$ & 70,0 \\
\hline S-19 & 72,2 & S-53 & 71,1 & S-87 & 68,6 & & & E-19 & 68,7 & $\mathrm{~L}-19$ & 74,9 \\
\hline S-20 & 70,7 & S-54 & 74,1 & S-88 & 68,3 & & & $\mathrm{E}-20$ & 70,2 & $\mathrm{~L}-20$ & 73,7 \\
\hline S-21 & 78,2 & S-55 & 80,0 & $\mathrm{~S}-89$ & 72,2 & & & $\mathrm{E}-21$ & 75,6 & $\mathrm{~L}-21$ & 74,5 \\
\hline $\mathrm{S}-22$ & 74,7 & S-56 & 73,7 & $\mathrm{~S}-90$ & 73,4 & & & E-22 & 69,8 & $\mathrm{~L}-22$ & 73,6 \\
\hline S-23 & 80,0 & S-57 & 69,9 & S-91 & 74,9 & & & E-23 & 73,0 & $\mathrm{~L}-23$ & 72,3 \\
\hline S-24 & 75,4 & S-58 & 73,4 & S-92 & 70,6 & & & $\mathrm{E}-24$ & 71,0 & $\mathrm{~L}-24$ & 76,2 \\
\hline S-25 & 71,8 & S-59 & 76,4 & $\mathrm{~S}-93$ & 72,4 & & & $\mathrm{E}-25$ & 69,1 & $\mathrm{~L}-25$ & 76,2 \\
\hline S-26 & 76,0 & S- 60 & 70,7 & S-94 & 70,0 & & & E-26 & 70,8 & $\mathrm{~L}-26$ & 74,7 \\
\hline S-27 & 68,2 & S-61 & 73,0 & & & & & E-27 & 73,1 & $\mathrm{~L}-27$ & 77,9 \\
\hline S-28 & 73,7 & S-62 & 68,1 & & & & & & & $\mathrm{~L}-28$ & 75,7 \\
\hline S-29 & 68,5 & S-63 & 70,9 & & & & & & & L-29 & 76,8 \\
\hline S-30 & 73,4 & S-64 & 70,7 & & & & & & & $\mathrm{~L}-30$ & 76,2 \\
\hline S-31 & 69,1 & S-65 & 71,6 & & & & & & & L-31 & 76,6 \\
\hline S-32 & 68,3 & S-66 & 75,2 & & & & & & & L-32 & 73,1 \\
\hline S-33 & 75,2 & S-67 & 72,4 & & & & & & & L-33 & 76,3 \\
\hline S-34 & 73,8 & S-68 & 74,3 & & & & & & & L-34 & 74,9 \\
\hline
\end{tabular}


Com base na análise estatística (Tabela 11), somente amostras de méis de flores de eucalipto e silvestres não diferiram entre si ao nível de $5 \%$ de significância. Amostras de méis de flores de laranjeira tiveram a maior média, e as de "méis" de exsudato de cana-de-açúcar, a menor.

Tabela 11. Valores médios de açúcares redutores $(\overline{\mathrm{m}})$, expresso em glicose, desvio padrão da média $(s(\overline{\mathrm{m}}))$, intervalo de variação (i.v.) e número $(\mathrm{n})$ de amostras de méis de flores silvestres, de eucalipto, de laranjeira e de "méis" de exsudato de cana-de-açúcar coletadas em municípios do Estado de São Paulo.

\begin{tabular}{lccc}
\hline \multicolumn{1}{c}{ Méis/"Méis" } & $\mathrm{n}$ & $\overline{\mathrm{m}} \pm \mathrm{s}(\overline{\mathrm{m}})$ & i.v. \\
\hline Laranjeira & 34 & $74,6 \pm 0,33 \mathrm{a}$ & 68,6 a 77,9 \\
Silvestre & 94 & $72,6 \pm 0,38 \mathrm{~b}$ & 53,2 a 80,0 \\
Eucalipto & 27 & $72,3 \pm 0,47 \mathrm{~b}$ & 67,7 a 77,1 \\
Cana-de-açúcar & 5 & $68,2 \pm 0,68 \mathrm{c}$ & 66,0 a 70,2 \\
\hline
\end{tabular}

Médias seguidas de diferentes letras não diferem estatisticamente, pelo teste de Tukey, ao nível de $5 \%$ de significância.

No presente trabalho, a umidade (segunda maior média $=18,7 \%$ ) e açúcares redutores (menor média $=68,2 \%$ ) das amostras de "méis" de exsudato de canade-açúcar, apresentaram o mesmo comportamento encontrado por Gómez et al. (1990) em suas amostras de "méis" de cana-de-açúcar em relação as demais estudadas.

Moraes \& Mantovani (1986) obtiveram para amostras de "méis" de cana $(69,11 \%)$, amostras de méis de flores de laranjeira $(75,90 \%)$, de flores silvestres $(75,7 \%)$, valores superiores aos das amostras correspondentes desta pesquisa.

Várias amostras de méis da presente pesquisa apresentaram valores de açúcares redutores abaixo do mínimo exigido pela legislação brasileira (mínimo $72 \%$ ). Um baixo valor de açúcares redutores (58\%) também foi encontrado por Mesallan \& ElShaarawy (1987) para uma das amostras de méis por eles analisadas.

Valores médios de açúcares redutores superiores aos encontrados no presente estudo foram apresentados por Flechtmann et al. (1963), tais como, 81,9; 80,8; 81,8 e $80,1 \%$, respectivamente para amostras de méis de flores silvestres, de eucalipto, de laranjeira e de "méis" de exsudato de cana-de-açúcar. 
De acordo com os valores médios de açúcares redutores somente amostras de "méis" de exsudato de cana-de-açúcar não atingiram o valor mínimo estabelecido pela legislação. Quanto às demais, houve certa porcentagem que não se enquadrou nas especificações estabelecidas (Figura 9).

Comparando-se aos padrões europeus para açúcares redutores, $55 \%$ das 41 amostras estudadas por Thrasyvoulou et al. (1982) foi considerada aceitável. Com relação ã legislação venezuelana, $88,8 \%$ das amostras foi considerada aceitável por VitOliver (1988). 

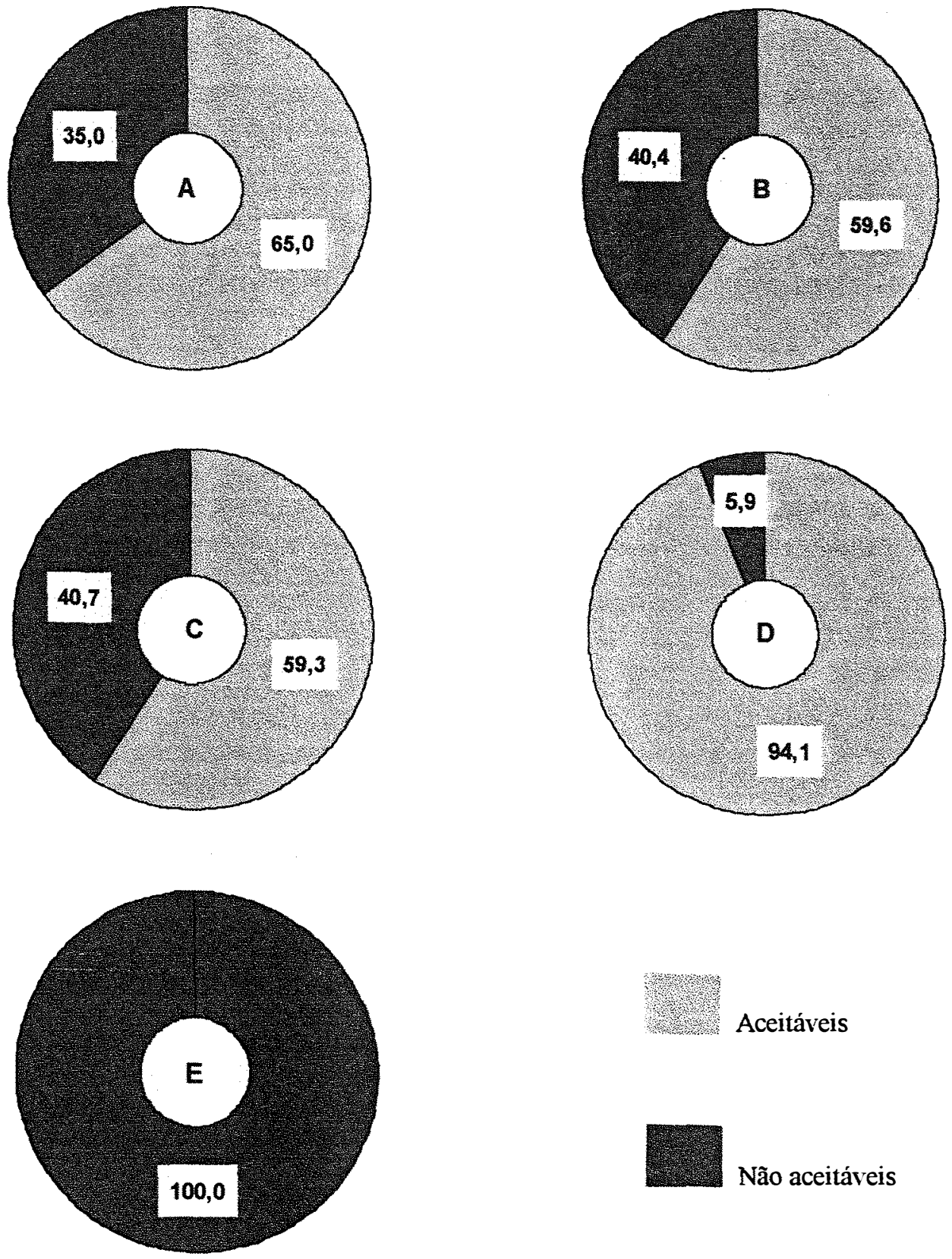

Aceitáveis

Não aceitáveis

Figura 9. Porcentagens do conjunto de todas as amostras estudadas (A), de méis de flores silvestres (B), de eucalipto (C), de laranjeira (D) e de "méis" de exsudato de cana-de-açúcar (E), que são ou não aceitáveis segundo especificações da legislação brasileira para açúcares redutores. 


\subsection{Sacarose}

As quantidades de sacarose calculada (\%) das amostras de méis de flores silvestres, de eucalipto, de laranjeira e de "méis" de exsudato de cana-de-açúcar são apresentados no Quadro X. 
Quadro X. Valores de sacarose (\%) das amostras de méis de flores silvestres, de eucalipto, de laranjeira e de "méis" de exsudato de cana-de-açúcar coletadas em municípios do Estado de São Paulo.

\begin{tabular}{|c|c|c|c|c|c|c|c|c|c|c|c|}
\hline \multicolumn{6}{|c|}{ Silvestre } & \multicolumn{2}{|c|}{$\begin{array}{l}\text { Cana-de- } \\
\text { açúcar }\end{array}$} & \multicolumn{2}{|c|}{ Eucalipto } & \multicolumn{2}{|c|}{ Laranjeira } \\
\hline S-01 & 11,8 & $\mathrm{~S}-35$ & 2,8 & S-69 & 3,5 & C-01 & 0,2 & E-01 & 1,3 & L-01 & 2,9 \\
\hline S-02 & 0,4 & S-36 & 1,2 & $\mathrm{~S}-70$ & 0,2 & $\mathrm{C}-02$ & 3,4 & E-02 & 3,5 & L-02 & 1,9 \\
\hline S-03 & 5,2 & S-37 & 2,5 & $S-71$ & 1,5 & C-03 & 2,8 & E-03 & 15,2 & $\mathrm{~L}-03$ & 2,0 \\
\hline $\mathrm{S}-04$ & 0,1 & S-38 & 4,8 & S-72 & 3,4 & C-04 & 1,5 & E-04 & 1,0 & L-04 & 1,2 \\
\hline S-05 & 1,4 & S-39 & 0,5 & S-73 & 3,3 & C-05 & 0,2 & E-05 & 1,2 & $\mathrm{~L}-05$ & 2,5 \\
\hline S-06 & 3,6 & $\mathrm{~S}-40$ & 0,2 & S-74 & 1,9 & & & E-06 & 2,6 & L-06 & 1,1 \\
\hline S-07 & 0,8 & S-41 & 4,5 & S-75 & 2,8 & & & E-07 & 1,5 & $\mathrm{~L}-07$ & 0,7 \\
\hline S-08 & 1,0 & S-42 & 3,1 & S-76 & 3,3 & & & E-08 & 1,5 & $\mathrm{~L}-08$ & 0,4 \\
\hline S-09 & 3,5 & S-43 & 1,6 & S-77 & 2,0 & & & E-09 & 1,1 & $\mathrm{~L}-09$ & 1,5 \\
\hline$S-10$ & 0,2 & S-44 & 1,6 & S-78 & 1,8 & & & E-10 & 4,2 & $\mathrm{~L}-10$ & 3,6 \\
\hline S-11 & 0,2 & S-45 & 1,9 & S-79 & 0,3 & & & E-11 & 1,6 & $\mathrm{~L}-11$ & 2,1 \\
\hline $\mathrm{S}-12$ & 0,2 & S-46 & 0,5 & S-80 & 1,1 & & & E-12 & 5,6 & $\mathrm{~L}-12$ & 3,1 \\
\hline$S-13$ & 1,4 & $\mathrm{~S}-47$ & 0,3 & S-81 & 0,1 & & & E-13 & 2,1 & L-13 & 5,2 \\
\hline S-14 & 0,4 & S-48 & 2,8 & S-82 & 27,4 & & & E-14 & 0,4 & L-14 & 4,4 \\
\hline$S-15$ & 1,9 & $\mathrm{~S}-49$ & 1,9 & S-83 & 1,5 & & & E-15 & 1,2 & $\mathrm{~L}-15$ & 1,0 \\
\hline$S-16$ & 0,5 & S-50 & 3,7 & S-84 & 1,7 & & & E-16 & 2,0 & L-16 & 3,3 \\
\hline$S-17$ & 2,1 & $S-51$ & 3,1 & S-85 & 2,6 & & & E-17 & 0,1 & $\mathrm{~L}-17$ & 2,8 \\
\hline$S-18$ & 1,5 & S-52 & 5,8 & S-86 & 2,9 & & & $\mathrm{E}-18$ & 0,1 & $\mathrm{~L}-18$ & 4,9 \\
\hline S-19 & 0,3 & $\mathrm{~S}-53$ & 0,2 & S-87 & 6,9 & & & $\mathrm{E}-19$ & 2,9 & $\mathrm{~L}-19$ & 1,0 \\
\hline S-20 & 0,7 & S-54 & 0,6 & S-88 & 1,8 & & & E-20 & 4,7 & L-20 & 1,9 \\
\hline S-21 & 0,6 & S-55 & 0,3 & S-89 & 0,3 & & & E-21 & 0,4 & $\mathrm{~L}-21$ & 1,4 \\
\hline S-22 & 2,1 & S-56 & 2,8 & S-90 & 3,5 & & & E-22 & 3,8 & $\mathrm{~L}-22$ & 2,0 \\
\hline S-23 & 0,8 & S-57 & 3,5 & S-91 & 0,1 & & & $\mathrm{E}-23$ & 0,2 & $\mathrm{~L}-23$ & 0,6 \\
\hline S-24 & 1,1 & S-58 & 4,9 & S-92 & 1,9 & & & E-24 & 3,1 & $\mathrm{~L}-24$ & 1,2 \\
\hline S-25 & 5,9 & S-59 & 1,7 & S-93 & 1,8 & & & E-25 & 0,8 & L-25 & 0,8 \\
\hline S-26 & 0,6 & S-60 & 1,5 & S-94 & 4,8 & & & E-26 & 1,7 & $\mathrm{~L}-26$ & 2,1 \\
\hline S-27 & 4,8 & S-61 & 0,5 & & & & & E-27 & 1,0 & L-27 & 3,5 \\
\hline S-28 & 1,5 & S-62 & 1,3 & & & & & & & L-28 & 1,9 \\
\hline S-29 & 5,2 & S-63 & 2,2 & & & & & & & L-29 & 0,3 \\
\hline S-30 & 2,1 & S-64 & 1,0 & & & & & & & L-30 & 0,3 \\
\hline$S-31$ & 1,7 & S-65 & 1,7 & & & & & & & $\mathrm{~L}-31$ & 2,6 \\
\hline$S-32$ & 3,8 & S-66 & 1,8 & & & & & & & \begin{tabular}{|l|}
$\mathrm{L}-32$ \\
\end{tabular} & 1,0 \\
\hline S-33 & 0,2 & S-67 & 3,2 & & & & & & & L-33 & 0,8 \\
\hline S-34 & 2,0 & S-68 & 2,9 & & & & & & & $\mathrm{~L}-34$ & 1,5 \\
\hline
\end{tabular}


Baseando-se nos dados estatísticos ao nível de $5 \%$ de significância, as amostras estudadas não diferiram entre si (Tabela 12). Amostras de méis de flores silvestres e de eucalipto apresentaram o mesmo valor médio, maior que as de laranjeira e, amostras de "méis" de exsudato de cana-de-açúcar apresentaram o menor valor.

Tabela 12. Valores médios de sacarose $(\overline{\mathrm{m}})$, desvio padrão da média $(\mathrm{s}(\overline{\mathrm{m}}))$, intervalo de variação (i.v.) e número (n) de amostras de méis de flores silvestres, de eucalipto, de laranjeira e de "méis" de exsudato de cana-de-açúcar coletadas em municípios do Estado de São Paulo.

\begin{tabular}{lccc}
\hline \multicolumn{1}{c}{ Méis/"Méis" } & $\mathrm{n}$ & $\overline{\mathrm{m}} \pm \mathrm{s}(\overline{\mathrm{m}})$ & i.v. \\
\hline Silvestre & 94 & $2,4 \pm 0,33 \mathrm{a}$ & 0,2 a 27,4 \\
Eucalipto & 27 & $2,4 \pm 0,56 \mathrm{a}$ & 0,1 a 15,2 \\
Laranjeira & 34 & $2,0 \pm 0,22 \mathrm{a}$ & 0,3 a 5,2 \\
Cana-de-açúcar & 5 & $1,6 \pm 0,65 \mathrm{a}$ & 0,2 a 3,4 \\
\hline
\end{tabular}

Médias seguidas de mesma letra não diferem estatisticamente, pelo teste de Tukey, ao nível de $5 \%$ de significância.

Os valores médios de sacarose calculada, apresentados pelas referidas amostras, não excederam o valor máximo de $10 \%$ estabelecido pela legislação vigente, enquadrando-se nas especificações oficiais. Entretanto, embora pequenas, certas porcentagens das amostras de méis de flores silvestres e de eucalipto não são aceitas segundo a legislação (Figura 10). 

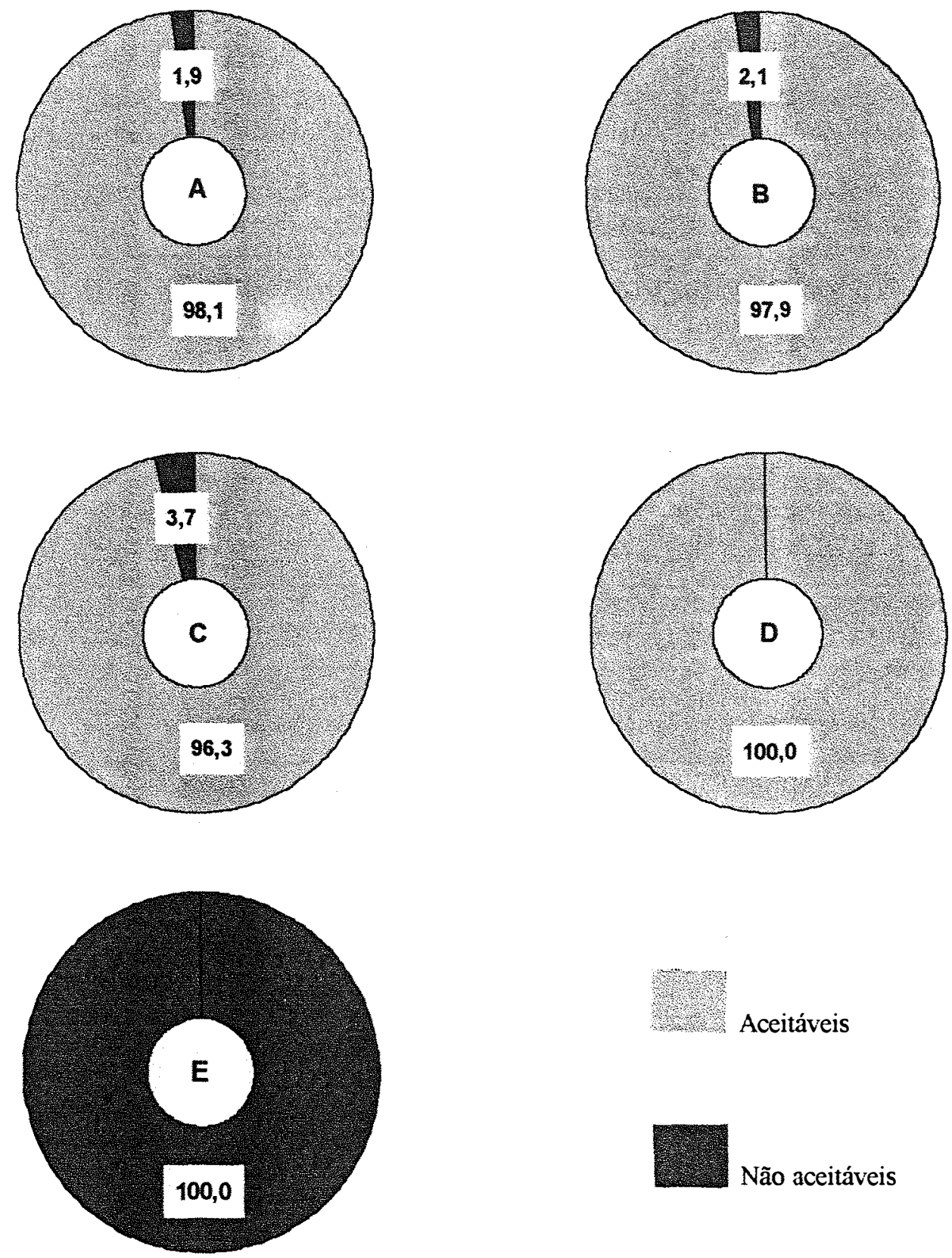

Figura 10. Porcentagens do conjunto de todas as amostras estudadas (A), de méis de flores silvestres (B), de eucalipto (C), de laranjeira (D) e de "méis" de exsudato de cana-de-açúcar (E), que são ou não aceitáveis segundo especificações da legislação brasileira para sacarose. 
Vit-Oliver (1988) em cálculo semelhante obteve $17,4 \%$ das amostras de méis analisadas fora das especificações exigidas. Thrasyvoulou et al. (1982) calcularam que $45 \%$ de 41 amostras não se enquadrou nos limites permitidos pelo padrão europeu.

As amostras de "méis" de exsudato de cana-de-açúcar estudadas, com valor médio de sacarose igual a $1,6 \%$, apresentaram a menor média, contrariamente à maior média encontrada por Gómez et al. (1990) também para exsudato de cana-deaçúcar.

Baixo valor de sacarose em amostras de méis de flores de eucalipto como encontrado por Serra-i-Bonvehi \& Canas-Lloria (1988) não foi verificado no presente estudo.

Entretanto, alto valor de sacarose $(27,4 \%$ ou $5,2 \%)$ também foi encontrado por Huidobro \& Simal (1984) que em amostras de méis espanhóis observaram $11,0 \%$ de sacarose. Frias-Tejera \& Torre (1991) também obtiveram um valor de $22,6 \%$ de sacarose, considerado bastante alto comparativamente aos valores oficiais. Dozo (1980) verificou que $1,5 \%$ do total de 66 amostras apresentou valores de sacarose maiores que $8 \%$.

Moraes \& Mantovani (1986) apresentaram valores de 1,3\%, 1,85\% e $1,87 \%$ de sacarose, respectivamente, para amostras de méis de flores silvestres, de laranjeira e de "méis" de cana-de-açúcar. Os teores apresentados para amostras de méis de flores silvestres e de laranjeira foram menores que os obtidos neste trabalho; já, o valor para amostras de "méis" de exsudato de cana-de-açúcar foi superior.

\subsection{Açúcares redutores totais}

Os teores de açúcares redutores totais (\%), expressos em glicose, das amostras de méis de flores silvestres, de eucalipto, de laranjeira e de "méis" de exsudato de cana-de-açúcar são apresentados no Quadro XI. 
Quadro XI. Valores de açúcares redutores totais (\%), expressos em glicose, das amostras de méis de flores silvestres, de eucalipto, de laranjeira e de "méis" de exsudato de cana-de-açúcar coletadas em municípios do Estado de São Paulo.

\begin{tabular}{|c|c|c|c|c|c|c|c|c|c|c|c|}
\hline \multicolumn{6}{|c|}{ Silvestre } & \multicolumn{2}{|c|}{$\begin{array}{l}\text { Cana-de- } \\
\text { açúcar }\end{array}$} & \multicolumn{2}{|c|}{ Eucalipto } & \multicolumn{2}{|c|}{ Laranjeira } \\
\hline S-01 & 78,8 & $\mathrm{~S}-35$ & 80,3 & S-69 & 76,5 & C-01 & 68,7 & E-01 & 75,7 & $\mathrm{~L}-01$ & 76,5 \\
\hline S-02 & 70,9 & S-36 & 78,2 & $S-70$ & 75,2 & C-02 & 69,6 & E-02 & 78,2 & $\mathrm{~L}-02$ & 77,5 \\
\hline S-03 & 73,3 & S-37 & 76,0 & S-71 & 73,2 & C-03 & 70,7 & E-03 & 88,3 & $\mathrm{~L}-03$ & 78,5 \\
\hline S-04 & 75,0 & $\mathrm{~S}-38$ & 76,6 & S-72 & 74,8 & C-04 & 71,7 & E-04 & 70,8 & L-04 & 75,4 \\
\hline $\mathrm{S}-05$ & 77,5 & S-39 & 74,6 & S-73 & 73,6 & C-05 & 68,8 & E-05 & 75,1 & $\mathrm{~L}-05$ & 71,2 \\
\hline S-06 & 76,0 & S-40 & 80,0 & S-74 & 74,8 & & & E-06 & 77,1 & L-06 & 75,6 \\
\hline S-07 & 78,3 & S-41 & 78,2 & S-75 & 78,6 & & & E-07 & 75,6 & $\mathrm{~L}-07$ & 77,1 \\
\hline S-08 & 78,0 & S-42 & 71,5 & S-76 & 77,8 & & & E-08 & 76,0 & \begin{tabular}{|l|}
$\mathrm{L}-08$ \\
\end{tabular} & 76,9 \\
\hline S-09 & 79,0 & $\mathrm{~S}-43$ & 76,0 & S-77 & 80,7 & & & E-09 & 78,3 & $\mathrm{~L}-09$ & \begin{tabular}{|l|}
74,4 \\
\end{tabular} \\
\hline $\mathrm{S}-10$ & 76,3 & S-44 & 72,6 & S-78 & 72,4 & & & E-10 & 75,6 & $\mathrm{~L}-10$ & 76,6 \\
\hline S-11 & 75,6 & S-45 & 76,8 & S-79 & 68,2 & & & E-11 & 74,4 & $\mathrm{~L}-11$ & 77,7 \\
\hline $\mathrm{S}-12$ & 77,7 & S-46 & 74,7 & $\mathrm{~S}-80$ & 71,3 & & & $\mathrm{E}-12$ & 75,1 & $\mathrm{~L}-12$ & 77,8 \\
\hline S-13 & 73,7 & S-47 & 74,8 & S-81 & 70,1 & & & E-13 & 75,2 & $\mathrm{~L}-13$ & 79,8 \\
\hline S-14 & 74,2 & S-48 & 75,9 & \begin{tabular}{|l|}
$\mathrm{S}-82$ \\
\end{tabular} & 82,0 & & & E-14 & 74,4 & $\mathrm{~L}-14$ & 77,4 \\
\hline S-15 & 75,8 & $\mathrm{~S}-49$ & 72,5 & \begin{tabular}{|l|}
$S-83$ \\
\end{tabular} & 74,4 & & & E-15 & 74,3 & $\mathrm{~L}-15$ & 76,3 \\
\hline S-16 & 75,7 & $\mathrm{~S}-50$ & 74,4 & S-84 & 69,6 & & & E-16 & 72,5 & $\mathrm{~L}-16$ & \begin{tabular}{|l|}
76,3 \\
\end{tabular} \\
\hline S-17 & 78,8 & S-51 & 72,6 & $\mathrm{~S}-85$ & 75,1 & & & $\mathrm{E}-17$ & 67,8 & L-17 & 77,2 \\
\hline S-18 & 72,1 & $\mathrm{~S}-52$ & 76,9 & S-86 & 72,7 & & & E-18 & 76,3 & L-18 & 75,2 \\
\hline S-19 & 72,5 & S-53 & 71,3 & S-87 & 75,9 & & & E-19 & 71,8 & L-19 & 75,9 \\
\hline S-20 & 71,4 & S-54 & 74,7 & S-88 & 70,2 & & & E-20 & 75,1 & $\mathrm{~L}-20$ & 75,7 \\
\hline S-21 & 78,8 & S-55 & 80,3 & S-89 & 72,5 & & & E-21 & 76,0 & \begin{tabular}{|l|}
$\mathrm{L}-21$ \\
\end{tabular} & 76,0 \\
\hline $\mathrm{S}-22$ & 76,9 & S-56 & 76,6 & S-90 & 77,1 & & & E-22 & 73,8 & $\mathrm{~L}-22$ & 75,7 \\
\hline $\mathrm{S}-23$ & 80,9 & S-57 & 73,6 & S-91 & 75,0 & & & E-23 & 73,2 & L-23 & 72,9 \\
\hline $\mathrm{S}-24$ & 76,6 & S-58 & 78,6 & S-92 & 72,6 & & & $\mathrm{E}-24$ & 74,3 & $\mathrm{~L}-24$ & 77,5 \\
\hline S-25 & 78,0 & S-59 & 78,2 & S-93 & 74,3 & & & E-25 & 70,0 & $\mathrm{~L}-25$ & 77,1 \\
\hline S-26 & 76,6 & S-60 & 72,3 & $\mathrm{~S}-94$ & 75,1 & & & E-26 & 72,6 & $\mathrm{~L}-26$ & 76,9 \\
\hline S-27 & 73,2 & S-61 & 73,5 & & & & & E-27 & 74,1 & $\mathrm{~L}-27$ & 81,6 \\
\hline $\mathrm{S}-28$ & 75,3 & S-62 & 69,5 & & & & & & & $\mathrm{~L}-28$ & 77,7 \\
\hline S-29 & 74,0 & S-63 & 73,2 & & & & & & & $\mathrm{~L}-29$ & 77,1 \\
\hline S-30 & 75,6 & S-64 & 71,8 & & & & & & & \begin{tabular}{|l}
$\mathrm{L}-30$ \\
\end{tabular} & 76,5 \\
\hline$S-31$ & 70,9 & S- 65 & 73,4 & & & & & & & L-31 & 79,3 \\
\hline $\mathrm{S}-32$ & 72,3 & S-66 & 77,1 & & & & & & & $\mathrm{~L}-32$ & 74,2 \\
\hline $\mathrm{S}-33$ & 75,4 & S-67 & 75,8 & & & & & & & L-33 & 77,1 \\
\hline S-34 & 75,9 & S-68 & 77,4 & & & & & & & L-34 & 76,5 \\
\hline
\end{tabular}


De acordo com a análise estatística, ao nível de $5 \%$ de significância, somente amostras de "méis" de exsudato de cana-de-açúcar diferiram das demais e, também, apresentaram o menor valor médio para açúcares redutores totais. As demais amostras de méis, com valores médios variando de 74,9 a $76,6 \%$, não diferiram entre si ao mesmo nível de significância (Tabela 13).

Tabela 13. Valores médios de açúcares redutores totais $(\overline{\mathrm{m}})$, desvio padrão da média $(\mathrm{s}(\overline{\mathrm{m}}))$, intervalo de variação (i.v.) e número (n) de amostras de méis de flores silvestres, de eucalipto, de laranjeira e de "méis" de exsudato de canade-açúcar coletadas em municípios do Estado de São Paulo.

\begin{tabular}{lccc}
\hline \multicolumn{1}{c}{ Méis/"Méis" } & $\mathrm{n}$ & $\overline{\mathrm{m}} \pm \mathrm{s}(\overline{\mathrm{m}})$ & i.v. \\
\hline Laranjeira & 34 & $76,6 \pm 0,32 \mathrm{a}$ & 71,2 a 81,6 \\
Silvestre & 94 & $75,2 \pm 0,29 \mathrm{a}$ & 68,2 a 82,0 \\
Eucalipto & 27 & $74,9 \pm 0,69 \mathrm{a}$ & 67,8 a 88,3 \\
Cana-de-açúcar & 5 & $69,9 \pm 0,58 \mathrm{~b}$ & 68,7 a 71,7 \\
\hline
\end{tabular}

Médias seguidas de diferentes letras diferem estatisticamente, pelo teste de Tukey, ao nível de $5 \%$ de significância. 


\section{CONCLUSÕES}

A caracterização do conjunto das amostras paulistas de méis de flores silvestres, de eucalipto, de laranjeira e de "méis" de exsudato de cana-de-açúcar é estabelecida por faixas de valores obtidas para cada parâmetro considerado: 16,0 a 23,4\% para umidade; 0,0 a 1,6 ml para proteína; 2,3 a 5,1 para $\mathrm{pH} ; 12,5$ a $75,5 \mathrm{meq} / \mathrm{kg}$ para acidez; 5,0 a $21,5 \mathrm{ml} / \mathrm{kg}$ para índice de formol; 5,0 a 38,5 para índice de diastase; 0,3 a $242,6 \mathrm{mg} / \mathrm{kg}$ para $\mathrm{HMF} ; 53,2$ a $80,0 \%$ para açúcares redutores e 0,1 a 27,4 para sacarose.

As porcentagens de amostras que se enquadram nas especificações da legislação brasileira para qualidade de mel para cada parâmetro estudado foram: 83,8\% para umidade; $40,6 \%$ para proteína; $44,4 \%$ para $\mathrm{pH} ; 80,0 \%$ para acidez; $94,4 \%$ para índice de formol; $93,7 \%$ para índice de diastase; $95,0 \%$ para HMF; $65,0 \%$ para açúcares redutores e $98,1 \%$ para sacarose. 


\section{REFERÊNCIAS BIBLIOGRÁFICAS}

ALMEIDA, R.P.; MARCHINI, L.C. Determinação protéica de diferentes tipos de méis. In: CONGRESSO BRASILEIRO DE APICULTURA, 7., Salvador, 1986. Programa e resumos. Salvador: Confederação Brasileira de Apicultura, 1986. p. 58.

AMARAL, A.D.; IMPERATRIZ-FONSECA, V.L.; GIOVANNINI, A.K.; AZOUBEL, M.L. Estudo comparativo entre amostras de méis com origem floral determinada; análise do teor de proteínas, lipídios e carboidratos totais. In: CONGRESSO BRASILEIRO DE APICULTURA, 7., Salvador, 1986. Programa e resumos. Salvador: Confederação Brasileira de Apicultura, 1986. p. 60.

ARCHENTI, A. Chemical composition of honeys from Chubut province (Argentina). Revista de Ciencias Agrarias, v.5, n.1/4, p. 12-28, 1984. /Resumo em CAB Abstracts on CD-ROM, v.2, 1987-89/.

ATAGO Co. Ltda. Refractômetro para mel. Abelhas ${ }_{2}$ v.31, n.362/363, p. 9, 11-12, 41, 44, 1988. / Resumo em CAB Abstracts on CD-ROM, v.2, 1987-89/.

BALENOVIC, J.; PERKOVAC, M.; PAPIC, J. Hydroxymethylfurfural content and amylase activity in honey. Prehrambeno Tehnoloska Revija, v.26, n.4, p. 143-6, 1988. /Resumo em CAB Abstracts on CD-ROM, v.3B, 1992/.

BOGDANOV, S.; RIEDER, K.; RUEGG, M. [New criteria for honey quality]. Apidologie, v.18, n.3, p. 267-78, 1987. 
BRASIL. Leis, decretos, etc. Decreto $\mathrm{n}^{\mathrm{o}}$ 30.691, de 02 de agosto de 1985. Diário Oficial, de 02 ago. 1985. Seção 1, p.1099-106. Aprova as Normas HigiênicoSanitárias.

BRICAGE, P. The amount of HMF in honeys does it have an effect on the health of the consumer? Bulletin Technique Apicole, v.16, n.4, p. 255-62, 1989. /Resumo em CAB Abstracts on CD-ROM, v.3A, 1990-91/.

BUTTA, A.; CASERIO, G.; BIZZOZERO, M.; COLOMBO, M. Indagine sulla qualità verceologica e sulle caratteristiche microbiologiche di mieli in commericio. Industrie Alimentari, v.22, n.210, p. 838-44, nov. 1983.

COLIN, M.E.; FLAMINI, C.; MALAUSSENE, J.; POURTALLIER, J. The quality of commercial honeys. Cahiers de Nutrition et de Dietetique, v.21, n.3, p. 219-22, 1986. /Resumo em CAB Abstracts on CD-ROM, v.2, 1987-89/.

CORNEJO, L.G. Tecnologia de miel. In: SEEMANN, P.; NEIRA, M., ed. Tecnologia de la produccion apicola. Valdivia: Universidad Austral de Chile, Facultad de Ciencias Agrarias, 1988. p. 145-71.

CORNEJO, L.G.; TOMASEVICH, R. Estudio sumario de la calidad de las mieles de algunas zonas del Estado de Rio Grande do Sul - Brasil. In: CONGRESSO BRASILEIRO DE APICULTURA, 1., Florianópolis, 1970. Florianópolis, APIMONDIA, 1970. p.241-5.

CRANE, E., ed. Honey: a comprehensive survey. London: Heinemann, 1975. 608p.

Del LUNGO, T.; CIURLO, R.; NOVARI, G.; MALERBA, A. Il miele argentino: produzione, commercializzazione e caratteristiche. Industrie Alimentari, v.30, n. 292, p. 361-6, abr. 1991.

DOZO, A.M.M. de. Determinacion de azucares en mieles producidas en la provincia de Buenos Aires - Republica Argentina. In: CONGRESSO BRASILEIRO DE 
APICULTURA， 5:; CONGRESSO LATINO-IBERO-AMERICANO DE APICULTURA, 3., Viçosa, 1980. Anais. Viçosa, UFV, 1980. p. 312-6.

EL-SHERBINY, G.A.; RIZK, S.S.; El-ASHWAH, F.A.; HEIKAL, H.A. Chemical composition of citrus honey producede in A.R.E. Agricultural Research Review, v.58, n.3, p. 289-97, 1980. /Resumo em CAB Abstracts on CD-ROM, v.1, 1984$86 /$.

ESCOBAR MARTÍNEZ, C.A.; GIMÉNEZ MEZA, G.G.; QUIÑONEZ MENDOZA, M.R. Mieles de abejas de flora paraguaya: composicion, tipificacion y normalizacion. San Lorenzo: Ministerio de Agricultura y Ganaderia; Universidad Nacional de Asuncion; Asociacion Suiza para el Desarrollo y la Cooperacion, 1992. $31 \mathrm{p}$.

ESTUDIO comparativo realizado por OCU mieles milflores. Vida Apicola, n.68, p. 3643, nov./dez. 1994.

FARAII-HAREMI, R.; HOSSEINI, Z. Chemical composition of honeys from Fars and Kohkiluyeh provinces of Iran. Iran Agricultural Research, v.6, n.2, p.73-81, 1987. /Resumo em CAB Abstracts on CD-ROM, v.3A, 1990-91/.

FERNÁNDEZ-SALGUERO, J.; GÓMEZ, R. Aportación al estudio de los alimentos españoles de humedad baja. Alimentaria, v.29, n.229, p. 83-5, jan./ fev. 1992.

FLECHTMANN, C.H.W.; CALDAS FILHO, C.F.; AMARAL, E.; ARZOLLA, J.D.P. Análise de méis do Estado de São Paulo. Boletim de Indústria Animal, v.21, p. 6573, dez. 1963.

FRIAS, I.; HARDISSON, A. Estudio de los parámetros analíticos de interés en la miel. II. Azúcares, cenizas y contenido mineral y color. Alimentaria, v.28, n.235, p. 41-3, set. 1992. 
FRIAS TEJERA, I.; TORRE, A.H. de la. Hidroxymethylfurfural e indice de diastase em mieles artesanales de la provincia de Santa Cruz de Tenerife. Alimentaria, v.27, n.216, p. 55-8, out. 1990 .

FRIAS-TEJERA, I.; TORRE, A.H. de la. Physico-chemical parameters of honey produced in the province of Santa Cruz in Tenerife. 4. Directly reducing sugars and sucrose. Canarias Apicola, n.24, p. 4-6, 1991. /Resumo em CAB Abstracts on CD-ROM, v.4A, 1993-94/.

FRIAS-TEJERA, I.; TORRE, A.H. de la.; HARDISSON, de la TORRE, A. Parametros fisico-quimicos en mieles elaboradas en la Provincia de Santa Cruz de Tenerife. I. Acidez e indice de formol. Canarias Apicola, n.20, p. 10-2, 1990. /Resumo em CAB Abstracts on CD-ROM, v.3A, 1990-91/.

FRILLI, F. Impuritã nel miele e negli alimenti che lo contengono: risultati di filth-test. /Resumo 3123 em Review of Applied Entomology. Series A, v.68, n.6, p. 392, June. $1980 /$.

GÓMEZ, R.; CABEZAS, L.; ALCALÁ, M; FERNÁNDEZ-SALGUERO, J. Determinacion y calculo de la actividad del agua en diferentes muestras de miel. Alimentaria, v.27, n.210, p. 33-6, mar. 1990.

HANKIN, L. Analysis of honey. Bulletin, Connecticut Agricultural Experiment Station, n.847, 6p., 1987. / Resumo 608 em Apicultural Abstracts, v.41, n.2, p. $165,1990 /$.

HASE, W.; AIDA, Y. Studies on the quality of honey on the market in Japan with special reference to its relation to the "Codex Alimentarius". In: INTERNATIONAL CONGRESS OF APICULTORE, 30., Nagowa, 1985. Apimondia, p. 338-42, 1986. /Resumo 290 em Apicultural Abstracts, v.39, n. 1, p. 77, 1988/.

HUIDOBRO, J.F.; SIMAL, J. Determination of sugars in honey. Anales de Bromatologia, v.36, n.2, p. 247-64, 1984. /Resumo em CAB Abstracts on CDROM, v.2, 1987-89/. 
MMPERATRIZ-FONSECA, V.L.; GIOVANNINI,A.; GUIBI, L.S.; AZOUBEL, M.L.; AMARAL, A.D. Preliminary study of Brazilian honeys. Apiacta, v.22, n.4, p. 11620, 1987. /Resumo em CAB Abstracts on CD-ROM, v.2, 1987-89/.

IVANOV, Ts.; CHERVENAKOVA, I. [Contents of some macro-, oligo-, and trace elements in honey, royal jelly and pollen.] Zhivotnovudni Nauki, v.21, n.6, p. 65-9, 1984. / Resumo 989 em Apicultural Abstracts, v.37, n. 3, p. 246, 1986/.

KASSAYE, A.; GARDEGABA, N. Moisture content determination of Ethiopian honey. In: INTERNATIONAL CONFERENCE ON APICULTURE IN TROPICAL CLIMATES, 4., Cairo, 1988. Proceedings. London: International Bee Research Association, 1989. p. 265-7. /Resumo 961 em Apicultural Abstracts, v.41, n.3, p. $260,1990 /$.

KIM, J.G.; KIM, M.K.; LEE, S.H. Study on the content of oligosaccharides in honeys from different honey plants. Korean Journal of Apiculture, v.8, n.2, p. 165-9, 1993. /Resumo em CAB Abstracts on CD-ROM, v.4A, 1993-94/.

$\mathrm{KOHLICH}, \mathrm{A}$; KRENN, H. [Values of chemical and physical parameters of honeys]. Mitteillungen Klosterneuburg Rebe und wein, obstbau und Fruchteverwertung, v.35, n.5, p. 210-7, 1985. / Resumo 1277 em Apicultural Abstracts, v.40, n.4, p. $358-9,1989 /$.

LEE, C.Y. Interaction of honey protein and tannic acid. Journal of Apicultural Research, v.23, n.2, p. 106-9, 1984.

LIN, Y.C.; SHEU, S.Y.; KONG, H.H. Physicochemical characteristics of certain Taiwan honeys. Taiwan ke Hsueh, v.31, n.1, p. 34-9, 1977. /Resumo 1440 em Apicultural Abstracts, v.30, n.4, p. 296, 1979/.

LOWER, E.S. Honey its properties and uses Part I. British Food Journal, v.89, n.938, p. 60-2, May/June. 1987a. 
LOWER, E.S. Honey its properties and uses Part II British Food Journal, v.89, n.939, p. 84-7, July/Aug. $1987 \mathrm{~b}$.

MAHAJAN, U. Physicochemical analysis of honey of Shimla Hills (Hemachal Pradesh) India, 1984. 99p. (Mphil Dissertation Himachal Pradesh University)./ Resumo 1360 em Apicultural Abstracts, v.36, n.4, p. 324, 1985/.

MARTINEZ-GOMEZ, M.E.; GUERRA HERNANDEZ, E.; MONTILLA GOMEZ, J.Y.; MOLINS MARIN, J.L. Physicochemical analysis of Spanish commercial Eucalyptus honeys. Journal of Apicultural Research, v.32, n.3/4, p. 121-6, 1993.

MESALLAN, A.S.; EL-SHAARAWY, M.I. Quality attributes of honey in Saudi Arabia. Food Chemistry, v.25, n.1, p. 1-11, 1987.

MIELE e melassa in polvere, nuovi dolcificanti e miglioranti per pane e biscotti. Industrie Alimentari, v.12, n.4, p. 74-6, 1973.

MORAES, R.M. de. Análise química do mel: manual técnico. Campinas: ITAL, 1988. $34 \mathrm{p}$.

MORAES, R.M. de.; MANTOVANI, D.M.B. Composição química de méis de diferentes fontes florais. In: CONGRESSO BRASILEIRO DE APICULTURA, 7., Salvador, 1986. Programa e resumos. Salvador: Confederação Brasileira de Apicultura, 1986. p. 58.

MORAES, R.M. de.; BENEVIDES. L.H.T.S.; MENEZES, A. de.; BARRETO PRATA, M.; BARBOSA, L.H. A desumificação do mel no Brasil. Apicultura \& Polinização, n.31, p.27-9, 1989.

NARAYAMA, N. Studies in Indian honeys and bees waxes. Poona: Central Beee Research Institue, 1970. 13p. /Resumo 420 em Apicultural Abstracts, v.24, n.2, p. 90, 1973/. 
NATARAJAN, R.; YESUVADIAN, M.S. Project report for a honey concentration equipament. Indian Honey, v.1, n.1, p.15-21, 1978. /Resumo em CAB Abstracts on CD-ROM, v.1, 1984-86/.

NAUTA, V.S.di. Alcume caratteristiche merceologiche e commerciali del miele. Industrie Alimentari, v.22, n.208, p. 624-9, set. 1983.

OLEK, A.; STEINKRAUS, K.H.; MATTICHK, L.R.; MUEGO, K.; UNDERWOOD, B.A.; MORSE, R.A. Carbohydrate composition of two nepalese honeys produced by Apis laboriosa and Apis cerana. Journal of Apicultural Research, v.26, n.3, p. 203-4, 1987.

PAPOFF, C.M.; CAMPUS, R.L.; CICU, M.F.I; FARRIS, G.G.; FLORIS, I.; RICCIARDELLI d'ALBORE, G. [Physical, chemical, microbiological and palinological characteristics of Somalian honeys]. Apicoltura, n.4, p.147-72, 1988. /Resumo em CAB Abstracts on CD-ROM, v.3A, 1990-91/.

PÉREZ, C.; CONCHELlO, P.; ARIÑO, A.; UCAR, A.; HERRERA, A. Estudio de algunos parametros fisico-quimicos en mieles monoflorales de Zaragoza. Alimentaria, v.27, n.213, p. 59-61, jun. 1990.

PERSANO-ODDO, L.; VALDI, E.; ACCORTI, M. Diastatic activity in some unifloral honeys. Apidologie, v.21, n.1, p. 17-24, 1990.

PFAU, L.A.; RUHLE, E.R. Concurso de mel: método de avaliar a qualidade do mel. In: CONGRESSO BRASILEIRO DE APICULTURA, 7., Salvador, 1986. Programa e resumos. Salvador: Confederação Brasileira de Apicultura, 1986. p. 58.

PHADKE, R.P. Studies on Indian honeys. 1. Proximate composition an physicochemical characteristics of Indian multifloral apiary honeys from Apis indica bees. Indian Bee Journal, v.29, p. 14-26, 1967. /Resumo 478 em Apicultural Abstracts, v. 23, n. 2 , p. $97-8,1972 /$. 
PIAZZA, M.G.; ACCORTI, M. [HMF of domestic and foreign honeys sold in Italy]. Apitalia, v.10, n.1, p. 8-10, 1983. /Resumo em CAB Abstracts on CD-ROM, v.1, 1984-86/.

PONCINI, L.; PRASAD, B.; SINGH, S.K.; WIMMER, F.L. A survey of some Fijian honeys. New Zealand Journal of Science, v.27, n.2, p. 141-4, 1984. /Resumo em CAB Abstracts on CD-ROM, v.1, 1984-86/.

PONCINI, L.; WIMMER, F.L. The composition of some Fiji honeys. Fiji Agricultural Journal, v.45, n.1, p. 25-9, 1983. /Resumo em CAB Abstracts on CD-ROM, v.1, 1984-86/.

PUBBLICATA una ricerca sulle caratteristiche di alcune qualitã di miele italiano. L'APE Nostra Amica, v.9, n.4, p. 17-21, 1987.

REIO, L.; ENGLUND, L. [Honey and its composition.] Var Föda, v.37, n.2, p. 42-62, 1985. /Resumo em CAB Abstracts on CD-ROM, v.2, 1987-89/.

RODRIGUEZ-OTERO, J.L.; PASEIRO, P.; SIMAL, J.; CEPEDA, A. Intento de caracterizacion de las mieles naturales de Galicia mediante las fracciones proteicas separadas por eletroforesis. Anales de Bromatologia, v.42, n.1, p. 83-98, 1990. /Resumo em CAB Abstracts on CD-ROM, v.4A, 1993-94/.

SALASHINSKII, N.A.; BARANOVA, Z.A.; KIBENKO, G.V. [Comparison of characteristics of honeys.] Tovarovedenie, v.13, p. 15-6, 1980. /Resumo $1363 \mathrm{em}$ Apicultural Abstracts, v.33, n.4, p. 295, 1982/.

SALINAS, F.; ESPINOSA-MANSILLA, A.; BERZAS-VEVADO, J.J. Flow-injection determination of HMF in honey by Winkler method. Fresenius' Journal of Analytical Chemistry, v.340, n.4, p. 250-2, 1991.

SANCHO, M.T.; MUNIATEGUI, S.; HUIDOBRO, J.F.; SIMAL-LOZANO, J. Provincial classification of Basque Country (northern Spain) honeys by their chemical composition. Journal of Apicultural Research, v.30, n.3/4, p. 168-72, 1991. 
SANCHO, M.T.; MUNIATEHUI, S.; HUIDOBRO, J.F.; SMMAL-LOZANO, J. Aging of honey. Journal of Agriculture and Food Chemistry, v.40, n.1, p. 134-8, 1992.

SERRA-i-BONVEHI, J.; CANAS-LLORIA, S. Physico-chemical properties, composition and pollen spectrum of Eucalyptus honey produced in Spain. Apicoltura, n.4, p. 59-81, 1988. /Resumo em CAB Abstracts on CD-ROM, v.3A, 1990-91/.

SPETTOLI, P.; CECCHINI, A.; MATCOVICH, P. Indigine sulle caratteristiche fisicochimiche di mieli del Friuli Orientale. Industrie Alimentari, v.22, n.210, p. 849-58, nov. 1983.

STONOGA, V.I.; FREITAS, R.J.S.de. Conteúdo de água e açúcares em mel de abelhas.

Boletim do Centro de Pesquisa e Processamento de Alimentos, v.9, n.1, p.9-16, jan./jun. 1991.

TABIO, C.; ALVAREZ, J.D.; BERISIARTU, M. Preliminary characterization of some physico-chemical and organoleptic characteristics of Citrus honeys from Jaguey Grande, Matanzas. Ciencia y Tecnica en la Agricultura - Apicultura, v.3, p. 2939, 1987. /Resumo em CAB Abstracts on CD-ROM, v.3A, 1990-91/.

TEMIZ, A.I. [Composition and characteristics of honeys from the Izmir region, and effects of different storage methods.] Ege Bolge Zirai Arastirma Enstitusu Yayinlari, n.31, p. xi, 11 3, 1983. /Resumo em CAB Abstracts on CD-ROM, v.1, 1984-86/.

THRASYVOULOU, A.; KARANASIOS, B.; INFANTIDIS, M. Some characteristics of Greek commercial honeys. Scientific Annals of the School of Agriculture, v.25, p. 51-63, 1982. /Resumo em CAB Abstracts on CD-ROM, v.1, 1984-86/.

THRASYVOULOU, A.; MANIKIS, J.; TSELIOS, D. Liquefying crystallized honey with ultrasonic waves. Apidologie, v.25, n.3, p. 297-302, 1994. 
THRASYVOULOU, A.T. The use of HMF and diastase as criteria of quality of Greek honey. Journal of Apicultural Research, v.25, n.3, p. 186-95, 1986.

TUVERI, F.; PROSPERI, S. Contributo alla conoscenza del miele prodotto in Sardegna. Industrie Alimentari, v.24, n.3, p. 259-62, mar. 1985.

VIDAL, R.; FREGOSI, E.V. de. Mel: caracteristicas, análises fisico-químicas, adulterações e transformacões. Barretos: Instituto Tecnológico Científico "Roberto Rios", 1984. 95p.

VIT-OLIVER, P. Classificacion de mieles commerciales venezolanas segun sus caracteristicas fisico-quimicas y organolepticas. Merida, 1988. 138p. Thesis Universidad de Los Andes. /Resumo em CAB Abstracts on CD-ROM, v.3A, 199091/.

VORWOHL, G.; SALEM, M.S.; NOUR, M.E. Chemical and physical properties of Egyptian honeys. In: INTERNATIONAL CONFERENCE ON APICULTURE IN TROPICAL CLIMATES, 4., Cairo, 1988. Proceedings. London: International Bee Research Association, 1989. p. 240-4. /Resumo 949 em Apicultural Abstracts, v.41, n. 3, p. $257,1990 /$.

WHITE, J.W.; WINTERS, K. Food Adulteration Honey Protein as Internal Standard for Stable Carbon Isotope Ratio Detection of Adulteration of Honey. Journal of the Association of Official Analytical Chemists, v.72, n.6, p. 907-11, 1989.

WHITE, J.W. Quality evaluation of honey: role of HMF and diastase assays. In: SEMINAR ON HONEY STANDARDS, TESTING PROCEDURES, AND QUALITY CONTROL, Riyadh, Saudi Arabia, 1991. Trabalhos apresentados. Riyadh, 1992. p. 25-50./Resumo em CAB Abstracts on CD-Rom, v.4A, 1993-94/.

WHITE, J.W. The role of HMF and diastase assays in honey quality evaluation. Bee World, v.75, n.3, p. 104-17, 1994. 
WHITE Jr., J.W. Hydroxymethylfurfural content of honey as an indicator of its adulteration wiht invert sugars. Bee World, v.61, n.1, p. 29-37, 1980.

WOOTTON, M.; RYALL, L. A comparison of Codex Alimentarius Commission and HPLC methods for 5-hidroxymethyl-2-furaldehyde determination in honey. Journal of Apicultural Research, v.24, n.2, p. 120-4, 1985. 